\title{
The effects of accelerated soil acidification on aggrading temperate deciduous forests: The Fernow Experimental Forest Long Term Soil Productivity (LTSP) Study at 13 years
}

\author{
Zachariah K. Fowler \\ West Virginia University
}

Follow this and additional works at: https://researchrepository.wvu.edu/etd

\section{Recommended Citation}

Fowler, Zachariah K., "The effects of accelerated soil acidification on aggrading temperate deciduous forests: The Fernow Experimental Forest Long Term Soil Productivity (LTSP) Study at 13 years" (2014). Graduate Theses, Dissertations, and Problem Reports. 403.

https://researchrepository.wvu.edu/etd/403

This Dissertation is protected by copyright and/or related rights. It has been brought to you by the The Research Repository @ WVU with permission from the rights-holder(s). You are free to use this Dissertation in any way that is permitted by the copyright and related rights legislation that applies to your use. For other uses you must obtain permission from the rights-holder(s) directly, unless additional rights are indicated by a Creative Commons license in the record and/ or on the work itself. This Dissertation has been accepted for inclusion in WVU Graduate Theses, Dissertations, and Problem Reports collection by an authorized administrator of The Research Repository @ WVU.

For more information, please contact researchrepository@mail.wvu.edu. 
The effects of accelerated soil acidification on aggrading temperate deciduous forests: The Fernow Experimental Forest Long Term Soil Productivity (LTSP) Study at 13 years.

\author{
Zachariah K. Fowler
}

Dissertation submitted to the Eberly College of Arts and Sciences at West Virginia University in partial fulfillment of the requirements for the degree of

\title{
Doctor of Philosophy in Biology
}

\author{
William T. Peterjohn, Ph. D., Chair \\ Mary Beth Adams, Ph. D. \\ Jonathan R. Cumming, Ph. D. \\ James B. McGraw, Ph. D. \\ Richard B. Thomas, Ph. D.
}

\section{Department of Biology Morgantown, West Virginia 2014}

Key Words: Nitrogen deposition, acidic deposition, carbon storage, soil acidification, calcium depletion, Fernow

Copyright 2014 Zachariah Fowler 


\begin{abstract}
The effects of accelerated soil acidification on aggrading temperate deciduous forests: The Fernow Experimental Forest Long Term Soil Productivity (LTSP) Study at 13 years.
\end{abstract}

\title{
Zachariah K. Fowler
}

Many temperate forests in the Eastern US are young and have experienced decades of elevated inputs of acidic compounds from the atmosphere. As a result, I used the Fernow Experimental Forest Long Term Soil Productivity (LTSP) experiment near Parsons, WV to determine how ongoing acidic deposition may affect total ecosystem carbon (C) storage, stand level dynamics, and soil and foliar chemistry in a young regrowing temperate deciduous forest. I also assessed the potential for acidic deposition effects to cascade up into higher trophic levels through its effects on a soil invertebrate. The LTSP experiment is a randomized block design in which ammonium sulfate is experimentally added to the soil in order to accelerate the acidification of forest soils in a way that is similar to the effects of long-term nitrogen $(\mathrm{N})$ deposition from the atmosphere.

I found that 13 years of ammonium sulfate additions to a regenerating deciduous forest stimulated its ability to store $\mathrm{C}$. This response was driven primarily by increased $\mathrm{C}$ storage in aboveground biomass and to a lesser extent by increased $\mathrm{C}$ stored in the forest floor. Despite the dominance of a single tree species, the overall response was a complex mixture of species-specific changes in the growth of individuals that may have been tempered by changes in stand density. I also found that after 10 years of growth with continual $\mathrm{N}$ and $\mathrm{S}$ additions, soil and foliar chemistry in an aggrading temperate deciduous forest show signs of soil acidification and calcium $(\mathrm{Ca})$ and magnesium $(\mathrm{Mg})$ depletion - suggesting that the ability of these regenerating forests to store $\mathrm{C}$ may diminish if acidification were to continue. Additionally, I found that liming may mitigate some of the negative impacts of acidification for experimental or management purposes. Finally, I also found that Pseudopolydesmus serratus millipedes, leaf litter processing invertebrates that contain high levels of $\mathrm{Ca}$, are negatively affected by 13 years of simulated acidic deposition in temperate deciduous forests. The negative effect of $\mathrm{N}$ addition on millipede populations, however, could not be tied to a depletion of $\mathrm{Ca}$ from the soil and plants but, if widespread, could affect the Ca supply to organisms, like some bird species, that have high $\mathrm{Ca}$ requirements during critical stages in their life.

Overall, this research suggests that young regrowing temperate deciduous forests may currently be sequestering more $\mathrm{C}$ due to inputs of $\mathrm{N}$ from acidic deposition. However, the positive response may involve species specific and stand-level changes and may be short-lived due to soil acidification effects, which should proceed, or co-occur with, reductions in growth rates. The effects of $\mathrm{N}$ deposition may also potentially reach higher trophic levels such as consumers of $P$. serratus, whose populations were negatively affected by $\mathrm{N}$ inputs. 


\section{Acknowledgements}

I would like to sincerely thank my advisor, Dr. Bill Peterjohn, and the rest of my committee, Drs. Mary Beth Adams, Jonathan Cumming, Jim McGraw, and Richard Thomas, for being excellent mentors and friends as I completed this research. Dr. Peterjohn especially deserves thanks for his never-dying belief in the fact that I would finish this degree and all of his help and support in making this possible. The biology department support staff was also invaluable. Without the opportunities and guidance that I got from these people, none of this could have happened.

I would also like to thank all of the Peterjohn Lab graduate students and interns past and present. There are lots of these people, and many of them helped me directly with this research. All of the other graduate students in the biology department also deserve thanks for being great colleagues in every way. Finally, I would like to thank my friends and my family, old and new, without whom I would not be happy at all in any endeavor. 


\section{Table of Contents}

Abstract

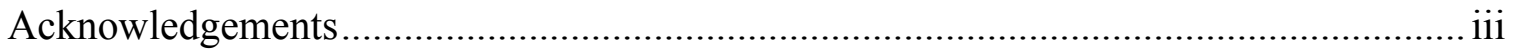

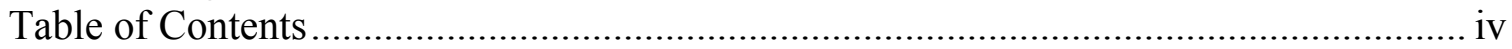

List of Figures ................................................................................................... vi

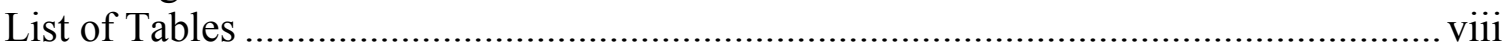

Chapter 1. Nitrogen deposition and its effects on young temperate forests: Carbon sinks, acidification effects, and forest organisms. ........................................................... 1

1.1. Elevated nitrogen deposition and carbon sinks in young forest stands. ................ 2

1.2. Nitrogen saturation and soil acidification and may constrain the extent and duration of nitrogen-induced forest growth and carbon sequestration in young temperate forest stands

1.3. Potential for effects of $\mathrm{N}$ deposition on temperate deciduous forests to be complex and involve community dynamics and stand level changes.

1.4. Potential for the effects of $\mathrm{N}$ deposition in temperate deciduous forests to feed into higher trophic levels.

1.5. Fernow Experimental Forest Long Term Soil Productivity (LTSP) experiment. 11

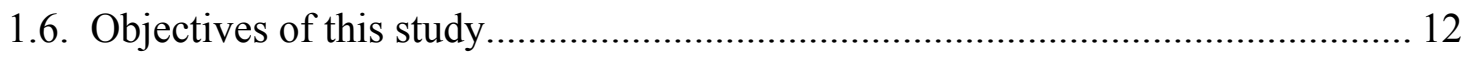

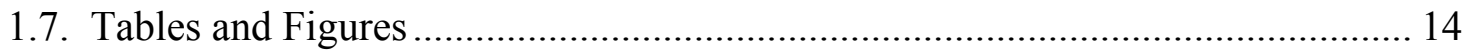

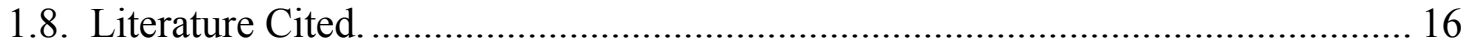

Chapter 2. Will more nitrogen enhance carbon storage in young forest stands in central Appalachia? ........................................................................................................................ 24

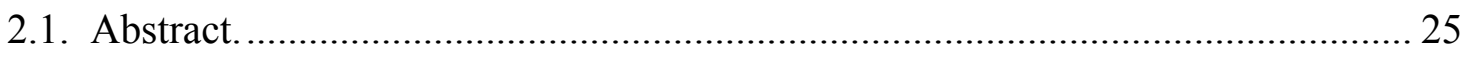

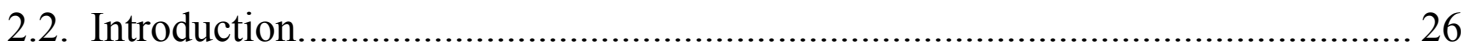

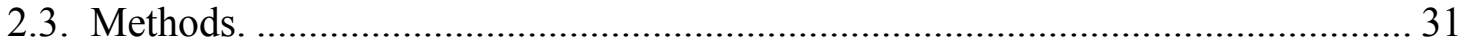

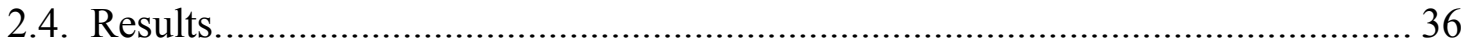

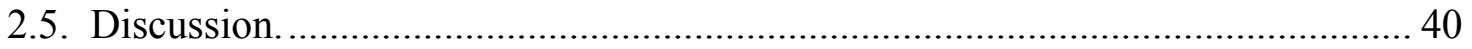

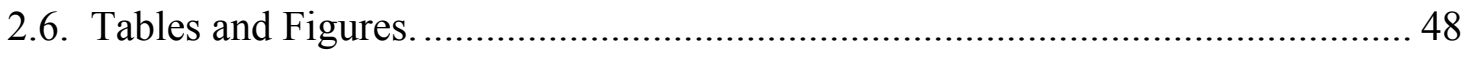

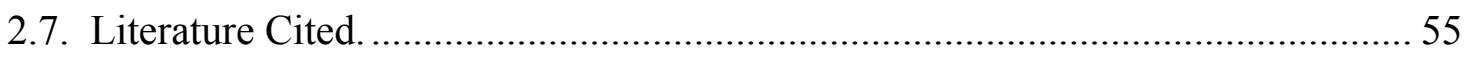


Chapter 3. Symptoms of soil acidification in young forest stands following enhanced nitrogen deposition: Evidence of changes in calcium, magnesium, and aluminum levels in soil and foliage.

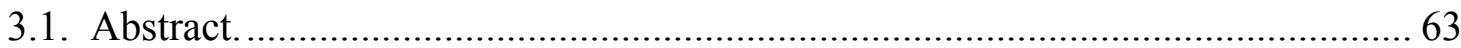

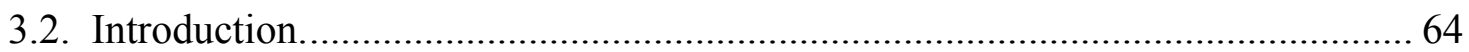

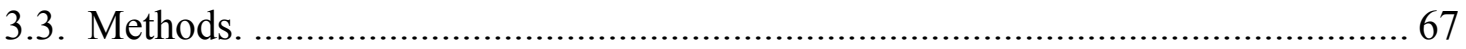

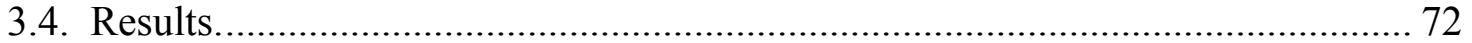

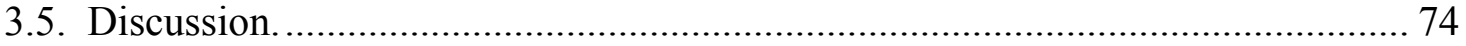

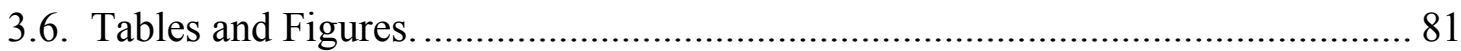

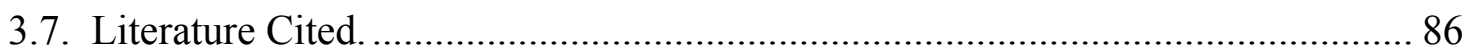

Chapter 4. Accelerated soil acidification in an aggrading temperate forest may decrease millipede populations by a mechanism unrelated to changes in calcium

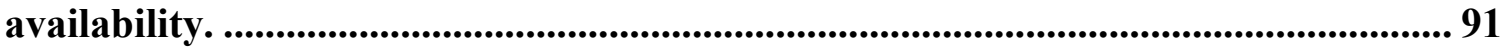

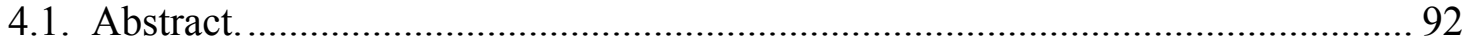

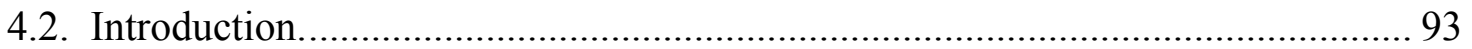

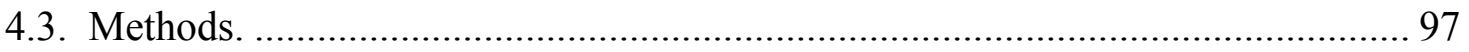

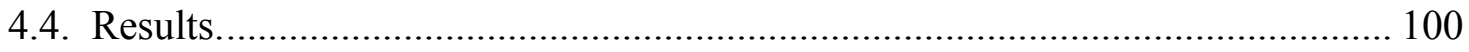

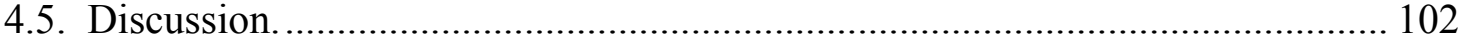

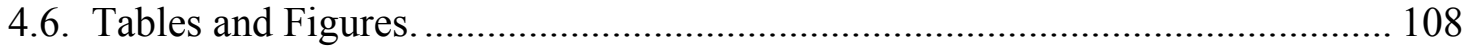

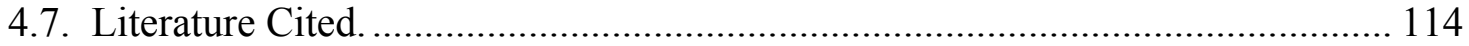

Chapter 5. General conclusions about the effects of accelerated soil acidification on aggrading temperate deciduous forests. .............................................................. 120

Appendix. Additional tables of data.............................................................................. 125 


\section{List of Figures}

Figure 1.1. Location of the Fernow Experimental Forest Long Term Soil Productivity (LTSP) experiment near Parsons, WV (Adams et al., 2004).....

Figure 1.2. The Fernow Experimental Forest Long Term Soil Productivity (LTSP) plots showing blocking and treatment distribution (Adams et al., 2004).

Figure 2.1. The LTSP plots at Fernow experimental forest. The x's in the expanded views represent the permanent stakes, and the expanded views illustrate how plots were divided into 12 or 192 squares for sampling purposes (Adams et al., 2004).....

Figure 2.2. Average total measured $\mathrm{C}$ pool after 13 years of treatment. Total measured $\mathrm{C}$ pool includes aboveground tree biomass, the forest floor, fine roots in the top $10 \mathrm{~cm}$, and the top $5 \mathrm{~cm}$ soil. Error bars are one standard error, and bars with different letters had significantly different means at $\mathrm{p}<0.05$ in post hoc analysis.

Figure 2.3. Average $\mathrm{C}$ pools after 13 years of treatment. Error bars are one standard error, values with different capital letters are significantly different $(p<0.05)$, and those with different lowercase letters show a trend towards differences $(\mathrm{p}<0.1)$ in post hoc analyses.

Figure 2.4. Average biomass per tree and density of trees per area after 13 years of treatment, regardless of species. Error bars are one standard error, and bars with different letters were found to have different means in post hoc analysis.

Figure 2.5. Average species richness of trees in total area sampled per plot after 13 years of treatment. Error bars are one standard error, and bars with different letters had significantly different means in post hoc analysis.

Figure 2.6. Average biomass per tree after 13 years of treatment by species. Each of the species which individually make up more than 5\% of the total RIV are considered. Error bars are one standard error. Data graphed are untransformed data, but statistics were done on $\log$ transformed data. (PRPE $=$ Prunus pensylvanica, LITU = Liriodendron tulipifera, $\mathrm{BELE}=$ Betula lenta, $\mathrm{PRSE}=$ Prunus serotina $)$ 54

Figure 3.1. The Fernow Experimental Forest Long Term Soil Productivity (LTSP) plots showing blocking and treatment distribution (Adams et al., 2004). 81

Figure 3.2. Mean soil $\mathrm{pH}$ in $0.1 \mathrm{M} \mathrm{CaCl}_{2}$ after 12 years of treatment. Error bars represent one standard error above and below the mean. Bars separated by different letters are significantly different at $\mathrm{p}<0.05$ in post hoc analysis. 
Figure 3.3. Mean soil chemistry measurements after 10 (resin) and 12 (extractable) years of treatment. Error bars represent one standard error above and below the mean. Bars separated by different letters are significantly different at $\mathrm{p}<0.05$ in post hoc analyses.

Figure 3.4. Mean values for foliar chemistry after 10 years of treatment. Error bars represent one standard error above and below the mean. Values separated by different capital letters are significantly different at $p<0.05$, and those separated by lowercase letters show a trend towards differences at $\mathrm{p}<0.1$ in post hoc analyses. (LITU $=$ Liriodendron tulipifera, $\mathrm{PRPE}=$ Prunus pensylvanica, $\mathrm{VIRO}=$ Viola rotundifolia $) \ldots . . .84$

Figure 3.5. Mean values for $\mathrm{Ca}$ : $\mathrm{Al}$ ratios after 10 (foliar and resin available) - 12 (exchangeable) years of treatment. Error bars represent one standard error above and below the mean. Values separated by lowercase letters show a trend towards differences at $\mathrm{p}<0.1$ in post hoc analyses. (LITU $=$ Liriodendron tulipifera, PRPE $=$ Prunus pensylvanica, $\mathrm{VIRO}=$ Viola rotundifolia $)$

Figure 4.1. Mean values for soil and foliar $\mathrm{Ca}$ levels for the Fernow Experimental Forest LTSP plots after 10 (resin and foliar) and 12 years (extractable) of treatment (Fowler et al., unpublished). Error bars represent one standard error above and below the mean. Values separated by different capital letters are significantly different at $p<0.05$, and those separated by lowercase letters show a trend towards differences at $\mathrm{p}<0.1$ in post hoc analyses. (LITU $=$ Liriodendron tulipifera, $\mathrm{PRPE}=$ Prunus pensylvanica, $\mathrm{VIRO}=$ Viola rotundifolia) 108

Figure 4.2. The Fernow Experimental Forest Long Term Soil Productivity (LTSP) plots showing blocking and treatment distribution (Adams et al., 2004).

Figure 4.3. Mean number and mass of millipedes collected after 13 years of treatment in the Fernow Experimental Forest Long Term Soil Productivity (LTSP) plots. Error bars represent one standard error above and below the mean.

Figure 4.4. Number of millipedes collected after 13 years of treatment in the Fernow Experimental Forest Long Term Soil Productivity (LTSP) plots shown by block and treatment to illustrate the source of the variation evident in Fig. 4.

Figure 4.5. Box plot for the residuals of the two-way ANOVA model for number of millipedes collected including and excluding block 4 . The line in the middle of each box represents the median of the residuals, the edges of the box are the $25^{\text {th }}$ and $75^{\text {th }}$

percentiles, and the whiskers are the $10^{\text {th }}$ and $90^{\text {th }}$ percentiles, outliers are shown as points beyond $90^{\text {th }}$ or $10^{\text {th }}$ percentiles. The two outliers evident when block 4 is included correspond to the low value for WT block 4 (plot 15) and the high value for WT+NS+LIME block 4 (plot 14) that can be seen in Fig. 5.

Figure 4.6. Mean number and mass of millipedes collected after 13 years of treatment in the Fernow Experimental Forest Long Term Soil Productivity (LTSP) plots, excluding block 4. Error bars represent one standard error above and below the mean. Bars separated by different letters are significantly different at $\mathrm{p}<0.05$ in post hoc analysis. 113 


\section{List of Tables}

Table 2.1. A list of all species found, the abbreviation used to represent each of them, and the total relative importance value for each. The relative importance value for each species was calculated regardless of treatment

Table A.1. Soil and foliar chemistry data after 10 (foliar and resin available) and 12 (extractable) years of treatment. Values presented are means (standard errors), and all statistics are for treatment effects. Values separated by different capital letters are significantly different at $\mathrm{p}<0.05$, and those separated by different lowercase letters show a trend towards differences at $\mathrm{p}<0.1$ in post hoc analyses. (LITU $=$ Liriodendron tulipifera, $\mathrm{PRPE}=$ Prunus pensylvanica, $\mathrm{VIRO}=$ Viola rotundifolia $).$ 126

Table A.2. Average values for all variables measured after 13 years of treatment in Fernow Experimental Forest LTSP. Values in parentheses are standard errors, and pvalues are for treatment effects. Values are also presented for the same data, excluding block 4 due data due to outliers. 
Chapter 1. Nitrogen deposition and its effects on young temperate forests: Carbon sinks, acidification effects, and forest organisms. 


\subsection{Elevated nitrogen deposition and carbon sinks in young forest stands.}

Acidic deposition is a major anthropogenic perturbation of ecosystems in the Eastern United States. Acidic deposition is caused by a combination of nitric and sulfuric acids produced in the atmosphere from pollutants released by fossil fuel burning as well as ammonium from agricultural industry pollution, which releases acidity when nitrified or taken up by plants (Driscoll et al., 2001). One of the major impacts of acidic deposition is that it supplies ecosystems with biologically available forms of nitrogen $(\mathrm{N})$ (nitrate, $\mathrm{NO}_{3}{ }^{-}$and ammonium, $\mathrm{NH}_{4}{ }^{+}$) and sulfur (S) (sulfate, $\mathrm{SO}_{4}{ }^{2-}$ ) at greater than pre-industrial levels (Galloway et al. 1976; Galloway et al. 1987). In the United States, Clean Air Act legislation in 1970 led to stabilization of the concentrations of $\mathrm{N}$ and reductions in the concentrations of S in precipitation (Baumgardner et al., 2002), and more regulation in 1990 resulted in a decline in $\mathrm{N}$ concentrations and a continued decline in $\mathrm{S}$ concentrations (US EPA, 2013). Despite these improvements, the levels of $\mathrm{N}$ and $\mathrm{S}$ in precipitation in the US, especially in the east, are still above pre-industrial background levels and likely will be for some time. Additionally, in other forested parts of the world, namely Asia, levels of $\mathrm{N}$ and $\mathrm{S}$ in precipitation are likely to continue to rise in the future (Galloway et al. 2004; Dentener et al., 2006). Due to the link between N limitation of forest productivity and the carbon (C) cycle, increases in $\mathrm{N}$ inputs into temperate deciduous forests may be implicated in sequestering anthropogenic carbon dioxide $\left(\mathrm{CO}_{2}\right)$.

Terrestrial ecosystems take up $\sim 28 \%(\sim 2.6 \mathrm{Pg} \mathrm{C} / \mathrm{yr})$ of anthropogenic $\mathrm{CO}_{2}$ emissions that cannot be accounted for by atmospheric accumulation or oceanic uptake (Houghton et al., 1998; Pan et al., 2011; Le Quere et al., 2012). If we understand the factors 
responsible for this residual terrestrial uptake, we will be better able to incorporate it into models and quantify how it will vary as a function of time or other changing variables including climate or soil conditions. Currently it is thought that a portion of this residual uptake occurs on land in the northern temperate latitudes (Ciais et al., 1995; Pan et al., 2011). Furthermore, it is estimated that forests in these latitudes, such as those in the Appalachian Mountains of Eastern US, are responsible for a large portion of the sink (Schimel, 1995).

Several mechanisms have been proposed for the creation and maintenance of the temperate forest $\mathrm{C}$ sink. Increased forest growth following logging or abandoning of agricultural land, as well as the maintenance of young, regrowing forests by various silvicultural practices have been implicated as primary contributors to the enhanced C uptake (Goodale et al., 2002). Increased growth of trees caused by increasing levels of atmospheric $\mathrm{CO}_{2}$ has also been suggested as being responsible for a portion of the terrestrial sink (Ainsworth and Long, 2005). Similarly, a fertilization effect by the biologically available nitrogen $(\mathrm{N})$ in acidic deposition may have increased growth of Nlimited forest trees (Aber and Driscoll, 1997; Thomas et al., 2010).

The effects of acidic precipitation on $\mathrm{C}$ storage in temperate deciduous forest ecosystems are complex and most likely non-linear. In the last twenty years there has been a great deal of research on the effect of $\mathrm{N}$ deposition on forest $\mathrm{C}$ storage. Modeling studies (Aber and Driscoll, 1997) and N addition experiments (Magill et al., 2004; Pregitzer et al., 2008), as well as more complex analyses combining models with field measurements 
(Magnani et al., 2007; Ollinger et al., 2008), have provided evidence that $\mathrm{N}$ deposition is at least in part responsible for an enhanced terrestrial $\mathrm{C}$ sink.

Although aboveground growth in temperate deciduous forests is often considered to be $\mathrm{N}$ limited, increasing $\mathrm{N}$ inputs, and $\mathrm{N}$ availability, generally decrease fine root biomass and the amount of C stored in this pool (Nadelhoffer, 2000; Nadelhoffer et al., 1985; Shuxia et al., 2010). The response of the root $C$ pool appears more likely to be linear than the aboveground $\mathrm{C}$ pool response. $\mathrm{N}$ inputs to temperate deciduous forests are also thought to affect decomposer bacterial and fungal community composition and extracellular enzyme activity in ways that will lead to increased C storage in the litter layer (Knorr et al., 2005) and soil (Whittinghill et al., 2012) pools of these forests. The litter-layer response is thought to be due to a reduction in decomposition of litter that has a greater lignin content combined with an increase in decomposition of litter with a greater abundance of cellulose (Fog, 1988). Similarly, the soil C pool is expected to increase in response to $\mathrm{N}$ deposition due to reduction in the decomposition of recalcitrant soil organic matter (Ramirez et al., 2012). Since the total response of the temperate deciduous forest $\mathrm{C}$ sink to $\mathrm{N}$ deposition will be the sum of these individual pool responses, understanding the response of each pool is important, but the greatest uncertainty seems to remain in understanding the response of aboveground tree growth at the forest level to $\mathrm{N}$ deposition. 


\subsection{Nitrogen saturation and soil acidification and may constrain the extent and duration of nitrogen-induced forest growth and carbon sequestration in young temperate forest stands.}

Although enhanced inputs of $\mathrm{N}$ to terrestrial ecosystems should initially stimulate productivity and $\mathrm{C}$ sequestration, it is thought that $\mathrm{N}$ saturation, or $\mathrm{N}$ availability in excess of plant and microbial demand, could diminish or even reverse the initial C storage stimulation through its effect on tree growth (Aber et al., 1998). Indeed, some $\mathrm{N}$ addition experiments suggest that the tree growth and $\mathrm{C}$ sink stimulation may be shortlived (DeWalle et al., 2006, Magill et al., 1996; McNulty et al., 2005), and ${ }^{15} \mathrm{~N}$ tracer studies (Nadelhoffer et al., 1999; Templer et al., 2012) have questioned the likelihood of an increase in aboveground $\mathrm{C}$ storage due to elevated $\mathrm{N}$ inputs. Additionally, other field studies (Boggs et al., 2005) have shown a neutral or mixed response to $\mathrm{N}$ inputs, and some (Elias et al., 2009; May et al., 2005) have even shown declines in forest growth due to $\mathrm{N}$ inputs.

Nitrogen saturation is a process that begins with the accumulation of chronic $\mathrm{N}$ inputs in the system, leading to enhanced rates of soil $\mathrm{NO}_{3}{ }^{-}$production (nitrification), and $\mathrm{NO}_{3}{ }^{-}$ leaching of from forest soils to receiving waters (Aber et al., 1998). The $\mathrm{NO}_{3}{ }^{-}$that leaches out carries with it cations to balance the charge of the solution, and in temperate deciduous forests these are often calcium $\left(\mathrm{Ca}^{2+}\right)$ and magnesium $\left(\mathrm{Mg}^{2+}\right)$, and hydrogen $\left(\mathrm{H}^{+}\right)$and aluminum $\left(\mathrm{Al}^{3+}\right)$ are left behind on the soil cation exchange complex. The outcome is soil acidification, leaching and eventual depletion of soil $\mathrm{Ca}^{2+}$ and $\mathrm{Mg}^{2+}$, and increases in soil levels of toxic $\mathrm{Al}^{3+}$ (Aber et al., 1998; Fernandez et al., 2003). This leaching induced acidification is supported by many independent studies including $\mathrm{N}$ 
addition studies in many forest types (Adams et al., 1997; Fernandez et al., 2003, Fernandez et al., 2010; Hogberg et al., 2006; Wallace et al., 2007), long-term soil data in areas receiving different levels of acidic deposition (Bailey et al., 2005; Bedison and Johnson, 2010; Farr et al., 2009; Likens et al., 1996; Miller and Watmough, 2009), and modeling studies (Chen and Driscoll, 2004; Gbondo-Tugbawa and Driscoll, 2003; Hruska et al., 2012). Additionally, the $\mathrm{Ca}$ to $\mathrm{Al}$ ratios in soil and foliage have been suggested to be an especially sensitive variable for detecting any negative effects of $\mathrm{N}$ deposition induced leaching and acidification (Cronan and Grigal, 1995).

The timing of forest responses to acidic deposition depends on the forest type, land-use history, and soil properties. Generally speaking, coniferous forests become N saturated at lower levels of cumulative $\mathrm{N}$ inputs than deciduous forests (Aber et al., 1998). Also, a history of $\mathrm{N}$ removal through logging means that young, fast-growing forests should accumulate more $\mathrm{N}$ inputs, and saturate more slowly, than mature, slow-growing forests (Fenn et al., 1998). A further factor is that different soils vary in their resilience to the leaching of $\mathrm{Ca}^{2+}$ and $\mathrm{Mg}^{2+}$ and acidification. Specifically, soils derived from predominantly base-poor parent materials (e.g. sandstone) will be affected negatively by $\mathrm{NO}_{3}{ }^{-}$leaching more quickly than soils derived from limestone containing parent material. Susceptible soils contain relatively low amounts of $\mathrm{Ca}$ and $\mathrm{Mg}$ initially and cannot replace loss quickly through weathering. A history of timber harvest also has the potential to significantly affect the soil's response to elevated $\mathrm{N}$ and $\mathrm{S}$ inputs because harvest can also remove large quantities of $\mathrm{Ca}$ and $\mathrm{Mg}$ (Adams et al., 2000). Many temperate deciduous forests of the Eastern US have a history of harvest and are underlain 
by sandstone-derived soils (Adams et al., 2000). Thus, these forests should be able to retain additional $\mathrm{N}$ inputs for some time due to a positive response of tree growth. However, once the later stages of $\mathrm{N}$ saturation begin, the negative effects could come relatively quickly and be hard to reverse.

Young, aggrading forests growing on soil derived from base-poor parent material are thus particularly valuable to study. Young, second-growth forests are already thought to be responsible for a portion of the residual terrestrial $\mathrm{C}$ sink due to their fast growth (Goodale et al., 2002), and they are expected to be able to retain significant amounts of added $\mathrm{N}$ and respond to $\mathrm{N}$ deposition with increased C storage (Fenn et al., 1998). Deciduous forests in the temperate latitudes, particularly those in the eastern US, exist (and recover from frequent disturbance) in regions that have received high levels of $\mathrm{N}$ deposition (Driscoll et al., 2001). Therefore, it is reasonable to think that $\mathrm{N}$ deposition would have a large impact on the $\mathrm{C}$ sink in these $\mathrm{N}$-limited, fast growing young forests recovering from disturbance. Many of these same forests, however, are growing on basepoor parent material (Adams et al., 2000) and also receive high levels of S deposition (Driscoll et al., 2001), predisposing them to the detrimental effects of soil acidification. Additionally, timber harvest, which is one of the most common disturbances, removes large quantities of the same nutrients depleted by $\mathrm{N}$ and $\mathrm{S}$ leaching (Adams et al., 2000).

While the complex link between acidic deposition and C sink potential in young, aggrading temperate deciduous forests is important to understand, it has not frequently been explicitly studied. While there have been several long-term $\mathrm{N}$ addition and 
acidification studies (Fernandez et al., 2010; Magill et al., 1996; Adams et al., 2006;

Wallace et al., 2007; Pregitzer et al., 2008; McNulty et al., 2005) and studies using deposition gradients (Bedison and McNeil, 2009; Boggs et al., 2005), all have been focused on the response of older, more established forests which leaves a significant gap in our understanding of how increased $\mathrm{N}$ additions may alter the function and composition of establishing forests.

\subsection{Potential for effects of $\mathbf{N}$ deposition on temperate deciduous forests to be complex and involve community dynamics and stand level changes.}

In addition to the direct positive or negative effects on changes in tree growth induced by chronically elevated $\mathrm{N}$ deposition, it is also possible that $\mathrm{N}$ deposition could result in long-lived alterations in forest $\mathrm{C}$ sequestration by changing stand dynamics and the composition of tree species. Little research has focused on the effect of $\mathrm{N}$ inputs on stand-level changes in regenerating forests where differential species responses to nutrient level changes could alter competitive relationships and community structure in later successional stages (Adams, 2003). However, work in old fields (Henry et al., 1999) and in grasslands and heathlands (Vitousek et al., 1997; Tilman 1993) demonstrated that elevated $\mathrm{N}$ inputs can significantly change community level variables and lead to lower plant species diversity. Also, research in temperate deciduous forests using a $\mathrm{N}$ deposition gradient (Boggs et al., 2005), forest inventory data (Thomas et al., 2010), and watershed fertilization (May et al., 2005; DeWalle et al. 2006) has shown that different tree species can respond differently to elevated N. It has also been found that more fertile sites have accelerated self-thinning resulting in fewer, larger trees than less 
fertile sites (Henry et al., 1999). Therefore, it seems likely that, given sufficient time, acidic deposition will change stand dynamics and/or tree species composition in temperate deciduous forests in ways that could significantly alter their capacity to sequester atmospheric $\mathrm{C}$.

\subsection{Potential for the effects of $\mathbf{N}$ deposition in temperate deciduous forests to feed into higher trophic levels.}

The impact of acidic deposition on nutrient content in soils is likely to be mirrored in the tissues of plants growing in these soils and the leaf litter they produce. For instance, foliar $\mathrm{Ca}$ and $\mathrm{Mg}$ levels are often correlated with soil availability of these nutrients (Lucash et al., 2012; Miller and Watmough, 2009). Declines in foliar Ca levels with increasing acidic deposition have been found in both gradient (Houle et al., 2007) and experimental addition studies (Elvir et al., 2006), as well as declines in the Ca levels of soil organic matter with time, attributed to acidic deposition (Johnson et al., 2008).

Altered soil and foliar Ca levels may affect soil- and litter-dwelling invertebrates, particularly those with exoskeletons containing high levels of Ca. Several researchers have found that the number and richness of snails is positively associated with the $\mathrm{pH}$ of soil, and with the Ca content of the soil and litter layer (Hotopp, 2002; Johannessen and Solhoy, 2001; Skeldon et al., 2007). Furthermore, Graveland and van der Wal (1996) tied declines in snail populations to acidic deposition through resultant soil $\mathrm{Ca}$ depletion. 
This decline in a Ca-rich food source as a result of acidic deposition has the potential to affect multiple trophic levels in an ecosystem, and even the ecosystem as a whole (Schaberg et al., 2001). This is because these invertebrates can be important in the transmission of $\mathrm{Ca}$ from the forest floor to birds and other vertebrates who can have high $\mathrm{Ca}$ requirements. Indeed, the link between acidic deposition and higher trophic level $\mathrm{Ca}$ depletion has been seen for snails and songbirds (Drent and Woldendorp, 1989), and acid deposition in the eastern US is thought to have contributed to the decline in the populations of wood thrush (Hames et al., 2002).

Many species of songbirds, even those that eat primarily seeds, vary their Ca intake by the season (Dhondt and Hochachka, 2001), consuming high-Ca food sources like snails during egg laying (Ankney and Scott, 1980), sometimes significantly changing their behavior to seek Ca-rich sources of food (Graveland and Berends, 1997). The increase in bird $\mathrm{Ca}$ demand is caused by the $\mathrm{Ca}$ requirement of eggshell formation, in combination with an inability to store heavy Ca reserves. The net result is that, without additional dietary Ca during egg laying, eggs may not form properly (Graveland, 1996; Graveland and van Gijzen, 1994). While most studies linking bird declines to acidic deposition through Ca depletion have focused on snails, Bures and Weidinger (2003) found that some birds, including flycatchers (Ficedula albicollis and Ficedula hypoleuca), need woodlice and millipedes as a source of $\mathrm{Ca}$ in addition to snails.

Millipedes are saprophagous macroarthropods that process forest leaf litter (David and Handa, 2010) and may be an important source of nutrition for some bird species (Bures 
and Weidinger, 2003). Millipedes are known to contain high concentrations of Ca, relative to most other soil and litter invertebrates except snails (Gist and Crossley, 1975;

Graveland and van Gijzen, 1994; Reichle et al., 1969). Calcium in millipedes strengthens their exoskeleton (Borrell, 2004), and millipede Ca concentrations can reflect environmental Ca concentrations (Nakamura and Taira, 2005; Nakamura et al., 2005). Evidence suggests that variability in available $\mathrm{Ca}$ can also alter millipede populations. For example, Kalisz and Powell (2003) reported that both snail and millipede numbers were associated with soil Ca variations due to distance from a limestone road. The diet of millipedes also can affect their level of reproduction or reproductive success (David and Celerier, 1997). Thus, changes in the nutrient levels in the food source of millipedes (forest floor litter) due to acidic deposition could lead to population level effects on millipedes. However, we are not aware of any studies linking $\mathrm{Ca}$ depletion due to acidic deposition to millipede abundance and Ca concentrations.

\subsection{Fernow Experimental Forest Long Term Soil Productivity (LTSP) experiment.}

The Fernow Experimental Forest LTSP study (Adams et al., 2004) provides a unique opportunity to study how experimental ammonium sulfate additions and acidification affect many aspects of a young aggrading temperate deciduous forest (Fig. 1.1). These replicated treatments, which were begun in 1996, include an unamended treatment (WT), an ammonium sulfate addition (WT+NS) to simulate additional acidic deposition, and an ammonium sulfate and dolomitic limestone addition (WT+NS+LIME) (Fig. 1.2). The lime addition should mitigate the negative effects of acidification and allow one to 
distinguish the effects of $\mathrm{N}$ inputs from the acidification effects. All of these treatment plots underwent a whole tree harvest (which was the second major logging event for the forest) just prior to onset of ammonium sulfate and lime treatments, and amendments have been ongoing through the entire life of the young forest. These plots are also located on soils derived from base-poor parent materials and in a region with a history of acidic deposition and logging. Soils are classified as loamy-skeletal, mixed active, mesic typic Dystrudepts and the parent materials are sandstone colluvium, sandstone residuum, and weathered shale (Adams et al., 2004). Temperate forests with these characteristics are relatively widespread (Adams et al., 2000) and may be responsible for part of the terrestrial residual $\mathrm{C}$ sink. Thus, it is important to understand the many ways that acidic deposition may influence these forests now and into the future.

\subsection{Objectives of this study.}

The research described in this dissertation was conducted at the Fernow Experimental Forest Long Term Soil Productivity Experiment (LTSP) and has three main objectives:

1. (Chapter 2) - To test whether $\mathrm{N}$ additions: a) directly increased aboveground growth of regenerating trees but did so in a way that was independent of the indirect effects of acidification; b) directly (independent of acidification effects) enhanced forest floor and soil $\mathrm{C}$ pools, and lowered the fine root $\mathrm{C}$ pool; c) lowered stand density and diversity; and d) differentially affected tree species by either $\mathrm{N}$ fertilization or soil acidification. 
2. (Chapter 3) - To examine nutrient levels in soil and foliar samples after at least 10 years of ammonium sulfate additions in order to determine if negative effects of acidification due to experimental $\mathrm{N}$ and $\mathrm{S}$ additions could be detected in soil and foliage. Specifically, I hypothesized that long-term ammonium sulfate additions to a young deciduous forest would lead to a decline in soil $\mathrm{pH}$, along with a decline in soil and foliar $\mathrm{Ca}$ and $\mathrm{Mg}$ levels and $\mathrm{Ca}: \mathrm{Al}$ ratios, and that soil and foliar $\mathrm{Al}$ levels would increase. I also attempted to determine if the concurrent addition of dolomitic limestone could mitigate these effects at the soil or foliar level.

3. (Chapter 4) - To assess the impact of long-term ammonium sulfate additions on the population size of Pseudopolydesmus serratus millipedes. I hypothesized that the effects of long-term $\mathrm{N}$ and $\mathrm{S}$ addition would lead to a smaller population of these millipedes in plots receiving elevated $\mathrm{N}$ and $\mathrm{S}$ inputs. I also hypothesized that the limestone addition would mitigate these negative effects due to its ability to ameliorate soil and foliar $\mathrm{Ca}$ reductions. 


\subsection{Tables and Figures}

Figure 1.1. Location of the Fernow Experimental Forest Long Term Soil Productivity (LTSP) experiment near Parsons, WV (Adams et al., 2004).

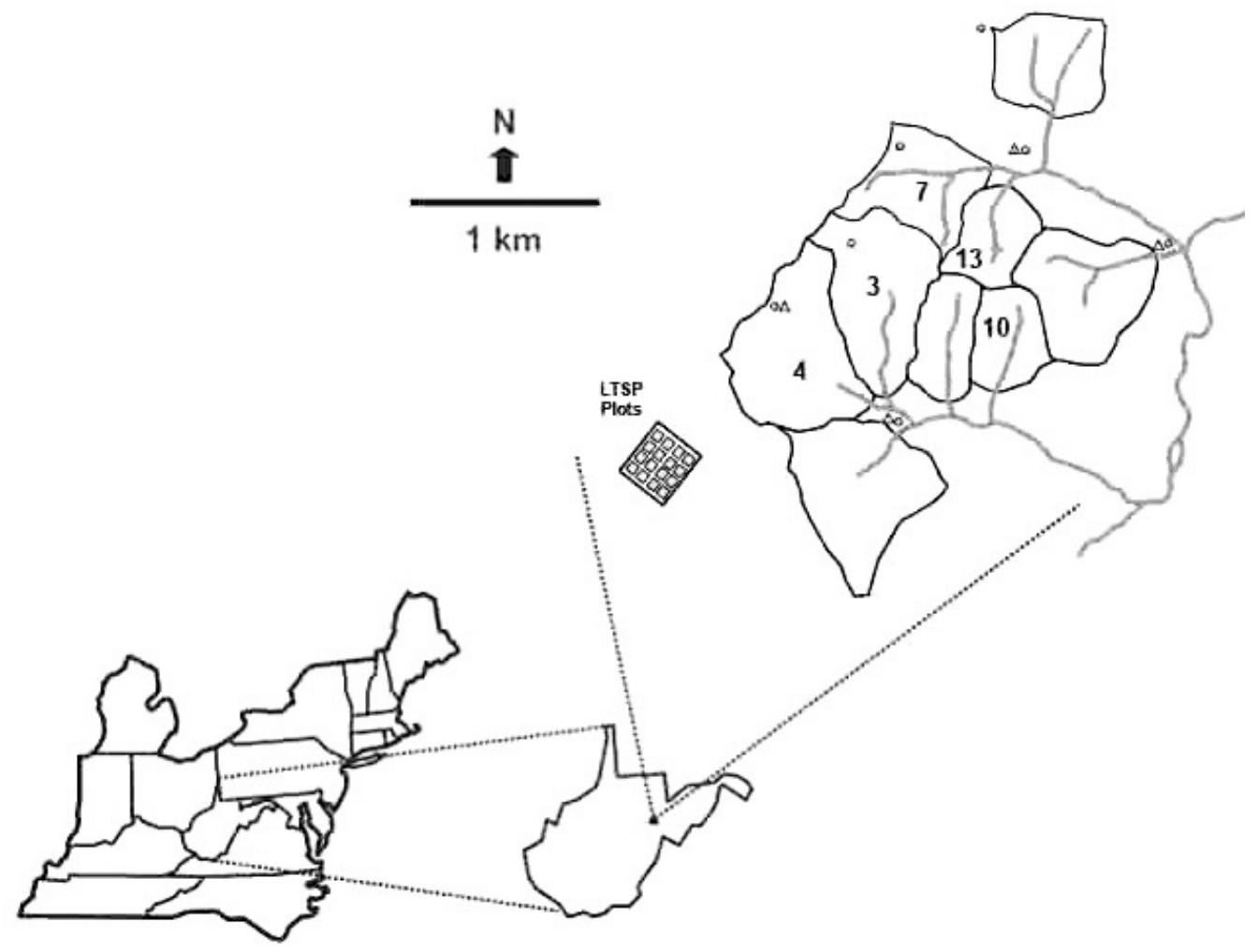


Figure 1.2. The Fernow Experimental Forest Long Term Soil Productivity (LTSP) plots showing blocking and treatment distribution (Adams et al., 2004).

\begin{tabular}{|c|c|c|c|c|}
\hline \multicolumn{4}{|c|}{ Top of slope } & \multirow[b]{2}{*}{ Block 1} \\
\hline $\begin{array}{c}\text { Plot } 4 \\
\text { UNCUT }\end{array}$ & $\begin{array}{c}\text { Plot } 3 \\
\text { WT }\end{array}$ & $\begin{array}{c}\text { Plot } 2 \\
\text { WT+NS+ } \\
\text { LIME }\end{array}$ & $\begin{array}{c}\text { Plot } 1 \\
\text { WT+NS }\end{array}$ & \\
\hline $\begin{array}{l}\text { Plot } 5 \\
\text { WT }\end{array}$ & $\begin{array}{c}\text { Plot } 6 \\
\text { WT+NS }\end{array}$ & $\begin{array}{c}\text { Plot } 7 \\
\text { WT+NS+ } \\
\text { LIME }\end{array}$ & $\begin{array}{c}\text { Plot } 8 \\
\text { UNCUT }\end{array}$ & \multirow[t]{3}{*}{ Block 2} \\
\hline $\begin{array}{l}\text { Plot } 12 \\
\text { WT }\end{array}$ & $\begin{array}{l}\text { Plot } 11 \\
\text { UNCUT }\end{array}$ & $\begin{array}{l}\text { Plot } 10 \\
\text { WT+NS }\end{array}$ & $\begin{array}{c}\text { Plot } 9 \\
\text { WT+NS+ } \\
\text { LIME }\end{array}$ & \\
\hline $\begin{array}{l}\text { Plot } 13 \\
\text { WT+NS }\end{array}$ & $\begin{array}{c}\text { Plot } 14 \\
\text { WT+NS+ } \\
\text { LIME }\end{array}$ & $\begin{array}{l}\text { Plot } 15 \\
\text { WT }\end{array}$ & $\begin{array}{l}\text { Plot } 16 \\
\text { UNCUT }\end{array}$ & \\
\hline \multicolumn{4}{|c|}{ Bottom of slope } & \\
\hline
\end{tabular}




\subsection{Literature Cited.}

Aber, J. D., K. J. Nadelhoffer, P. Steudlar, and J. M. Mellilo. 1989. Nitrogen saturation in northern forest ecosystems. BioScience 39: 378-386.

Aber, J. D. and C. T. Driscoll. 1997. Effects of land use, climate variation, and N deposition on $\mathrm{N}$ cycling and $\mathrm{C}$ storage in northern hardwood forests. Global Biogeochemical Cycles 11: 639-648.

Aber, J. D., W. McDowell, K. Nadelhoffer, A. Magill, G. Berntson, M. Kamakea, S. McNulty, W. Currie, L. Rustad, and I. Fernandez. 1998. Nitrogen saturation in temperate forest ecosystems. BioScience 48: 921-934.

Adams, M. B., T. R. Angradi, and J. N. Kochenderfer. 1997. Stream water and soil solution responses to 5 years of nitrogen and sulfur additions at the Fernow Experimental Forest, West Virginia. Forest Ecology and Management 95: 79-91.

Adams, M. B., J. A. Burger, A. B. Jenkins, and L. Zelazny. 2000. Impact of harvesting and atmospheric pollution on nutrient depletion of eastern US hardwood forests. Forest Ecology and Management 138: 301-319.

Adams, M. B. 2003. Ecological issues related to $\mathrm{N}$ deposition to natural ecosystems: research needs. Environment International 29: 189-199.

Adams, M. B., J. Burger, L. Zelazny, and J. Baumgras. 2004. Description of the Fork Mountain long-term soil productivity study: site characterization. USDA Forest Service, Newtown Square, PA.

Adams, M. B., D. R. DeWalle, and J. L. Hom., Eds. 2006. The Fernow watershed acidification study. Springer, The Netherlands.

Ainsworth, E. A. and S. P. Long. 2005. Tansley review. What have we learned from 15 years of free-air $\mathrm{CO} 2$ enrichment (FACE)? A meta-analytic review of the responses of phototsynthesis, canopy properties and plant production to rising CO2. New Phytologist 165: 351-372.

Ankney, C. D. and D. M. Scott. 1980. Changes in nutrient reserves and diet of breeding brown-headed cowbirds. The Auk 97: 684-696.

Bailey, S. W., S. B. Horsley, and R. P. Long. 2005. Thirty years of change in forest soils of the Allegheny Plateau, Pennsylvania. Soil Society of America Journal 69: 681-690. 
Baumgardner, R. E., T. F. Lavery, C. M. Rogers, and S. S. Isil. 2002. Estimates of the atmospheric deposition of sulfur and nitrogen Species: Clean air status and trends network, 1990-2000. Environmental Science and Technology 36: 2614-2629.

Bedison, J. E. and A. H. Johnson. 2010. Seventy-four years of calcium loss from forest soils of the Adirondack Mountains, New York. Soil Society of America Journal 74: $2187-2195$.

Bedison, J. E. and B. E. McNeil. 2009. Is the growth of temperate forest trees enhanced along an ambient nitrogen deposition gradient? Ecology 90: 1736-1742.

Boggs, J. L., S. G. McNulty, M. J. Gavazzi, and J. Moore Myers. 2005. Tree growth, foliar chemistry, and nitrogen cycling across a nitrogen deposition gradient in southern Appalachian deciduous forests. Canadian Journal of Forest Research 35: 1901-1913.

Borrell, B. 2004. Mechanical properties of calcified exoskeleton from the neotropical millipede, Nyssodesmus python. Journal of Insect Physiology 50: 1121-1126.

Bures, S. and K. Weidinger. 2003. Sources and timing of calcium intake during reproduction in flycatchers. Oecologia 137: 634-641.

Chen, L. and C. T. Driscoll. 2004. Modeling the response of soil and surface waters in the Adirondack and Catskill regions of New York to changes in atmospheric deposition and historical land disturbance. Atmospheric Environment 38: 40994109.

Ciais, P., P. P. Tans, M. Trolier, J. W. C. White, and R. J. Francey. 1995. A large Northern Hemisphere terrestrial $\mathrm{CO}_{2}$ sink indicated by the ${ }^{13} \mathrm{C} /{ }^{12} \mathrm{C}$ ratio of atmospheric $\mathrm{CO}_{2}$. Science 269: 1098-1102.

Cronan, C. S. and D. F. Grigal. 1995. Use of calcium/aluminum ratios as indicators of stress in forest ecosystems. Journal of Environmental Quality 24: 209-226.

David, J. F. and M. L. Celerier. 1997. Effects of yeast on the growth and reproduction of the saprophagous millipede Polydesmus angustus (Diplopoda Polydesmidae). Biol Fertil Soils 24: 66-69.

David, J. F. and I. T. Handa. 2010. The ecology of saprophagous macroarthropods (millipedes, woodlice) in the context of global change. Biological Reviews 85: 881-895. 
Dentener, F., D. Stevenson, K. Ellingsen, T. Van Noije, M. Schultz, M. Amann, C. Atherton, N. Bell, D. Bergmann, I. Bey, L. Bouwman, T. Buler, J. Cofala, B. Collins, J. Drevet, R. Doherty, B. Eickhout, H. Eskes, A. Fiore, M Gauss, D. Hauglustaine, L. Horowitz, I S. A. Isaksen, B. Josse, M. Lawrence, M. Krol, J. F. Lamarque, V. Montanaro, J. F. Muller, V. H. Peuch, G. Pitari, J. Pyle, S. Rast, J. Rodriguez, M. Sanderson, N. H. Savage, D. Shindell, S. Strahan, S. Szopa, K. Sudo, R. Van Dingenen, O. Wild, and G. Zeng. 2006. The global atmospheric environment for the next generation. Environmental Science and Technology 40: 3586-3594.

DeWalle, D. R., J. L. Hom, and M. B. Adams. 2006. Introduction to the Fernow watershed acidification study. In: M. B. Adams et al. (eds.), The Fernow watershed acidification study. Springer, The Netherlands: 1-16.

Dhondt, A. A. and W. M. Hochachka. 2001. Variations in calcium use by birds during the breeding season. The Condor 103: 592-598.

Drent, P. J. and J. W. Woldendorp. 1989. Acid rain and eggshells. Nature 339: 431.

Driscoll, C. T., G. B. Lawrence, A. J. Bulger, T. J. Butler, C. S. Cronan, C. Eagar, K. F. Lambert, G. E. Likens, J. L. Stoddard, and K. C. Weathers. 2001. Acidic deposition in the Northeastern United States: Sources and inputs, ecosystem effects, and management strategies. BioScience 51: 180-198.

Elias, P. E., J. A. Burger, and M. B. Adams. 2009. Acid deposition effects on forest composition and growth on the Monongahela National Forest, West Virginia. Forest Ecology and Management 258: 2175-2182.

Elvir, J. A., G. B. Wiersma, M. E. Day, M. S. Greenwood, and I. J. Fernandez. 2006. Effects of enhanced nitrogen deposition on foliar chemistry and physiological processes of forest trees at the Bear Brook Watershed in Maine. Forest Ecology and Management 221: 207-214.

Farr, C., J. Skousen, P. Edwards, S. Connolly, and J. Sencindiver. 2009. Acid soil indicators in forest soils of the Cherry River Watershed, West Virginia. Environmental Monitoring and assessment 158: 343-353.

Fenn, M. E., M. A. Poth, J. D. Aber, J. S. Baron, B. T. Bormann, D. W. Johnson, A. D. Lemly, S. G. McNulty, D. F. Ryan, and R. Stottlemyer. 1998. Nitrogen excess in North American ecosystems: Predisposing factors, ecosystem responses, and management Strategies. Ecological Applications 8: 706-733.

Fernandez, I. J., L. E. Rustad, S. A. Norton, J. S. Kahl, and B. J. Cosby. 2003. Experimental acidification causes soil base-cation depletion at the Bear Brook Watershed in Maine. Soil Society of America Journal 67: 1909-1919. 
Fernandez, I. J., M. B. Adams, M. D. SanClements, and S. A. Norton. 2010. Comparing decadal responses of whole-watershed manipulations at the Bear Brook and Fernow experiments. Environmental Monitoring and Assessment.

Fog, K. 1988. The effect of added nitrogen on the rate of decomposition of organic matter. Biological Reviews 63: 433-462.

Galloway, J. N., G. E. Likens, and E. S. Edgerton. 1976. Acid precipitation in the Northeastern United States: $\mathrm{pH}$ and acidity. Science 194: 722-724.

Galloway, J. N., Z. Dianwu, X. Jiling, and G. E. Likens. 1987. Acid rain: China, United States, and a remote area. Science 236: 1559-1562.

Galloway, J. N., F. J. Dentener, D. G. Capone, E. W. Boyer, R. W. Howarth, S. P. Seitzinger, G. P. Asner, C. C. Cleveland, P. A. Green, E. A. Holland, D. M. Karl, A. F. Michaels, J. H. Porter, A. R. Townsend, and C. J. Vorosmarty. 2004. Nitrogen cycles: past, present, and future. Biogeochemistry 70: 153-226.

Gbondo-Tugbawa, S. S. and C. T. Driscoll. 2003. Factors controlling long-term changes in soil pools of exchangeable basic cations and stream acid neutralizing capacity in a northern hardwood forest ecosystem. Biogeochemistry 63: 161-185.

Gist, C. S. and D. A. Crossley, Jr. 1975. The litter arthropod community in a Southern Appalachian hardwood forest: Numbers, biomass and mineral element content. American Midland Naturalist 93: 107-122.

Goodale, C. L., M. J. Apps, R. A. Birdsey, C. B. Field, L. S. Heath, R. A. Houghton, J. C. Jenkins, G. H. Kohlmaier, W. Kurtz, S. Liu, G. Nabuurs, S. Nilsson, and A. Z. Shvidenko. 2002. Forest carbon sinks in the northern hemisphere. Ecological Applications 12: 891-899.

Graveland, J. 1996. Avian eggshell formation in calcium-rich and calcium-poor habitats: importance of snail shells and anthropogenic calcium sources. Canadian Journal of Zoology 74: 1035-1044.

Graveland, J. and A. Berends. 1997. Timing of the calcium intake and effect of calcium deficiency on behaviour and egg laying in captive great tits, Parus major. Physiological Zoology 70: 74-84.

Graveland, J. and R. van der Wal. 1996. Decline in snail abundance due to soil acidification causes eggshell defects in forest passerines. Oecologia 105: 351360 .

Graveland, J. and T. van Gijzen. 1994. Arthropods and seeds are not sufficient as calcium sources for shell formation and skeletal growth in passerines. Ardea 82: 299-314. 
Hames, R. S., K. V. Rosenberg, J. D. Lowe, S. E. Barker, and A. A. Dhondt. 2002. Adverse effects of acid rain on the distribution of the wood thrush Hylocichla mustelina in North America. Proceedings of the National Academy of Sciences of the United States of America 99: 11235-11240.

Henry, M., H. Stevens, and W. P. Carson. 1999. The significance of assemblage-level thinning for species richness. Journal of Ecology 87: 490-502.

Hogberg, P., H. Fan, M. Quist, D. Binkley, and C. O. Tamm. 2006. Tree growth and soil acidification in response of 30 years of experimental nitrogen loading on boreal forest. Global Change Biology 12: 489-499.

Hruska, J., F. Oulehle, P. Samonil, J. Sebesta, K. Tahovska, R. Hleb, J. Houska, and J. Sik1. 2012. Long-term forest soil acidification, nutrient leaching and vegetation development: Linking modeling and surveys of a primeval spruce forest in the Ukrainian Transcarpathian Mts. Ecological modeling 244: 28-37.

Hotopp, K. P. 2002. Land snails and soil calcium in Central Appalachian Mountain forest. Southeastern Naturalist 1: 27-44.

Houghton, R. A., E. A. Davidson, and G. M. Woodwell. 1998. Missing sinks, feedbacks, and understanding the role of terrestrial ecosystems in the global carbon balance. Global Biogeochemical Cycles 12: 25-34.

Houle, D., S. Tremblay, and R. Ouimet. 2007. Foliar and wood chemistry of sugar maple along a gradient of soil acidity and stand health. Plant and Soil 300: 173183.

Johannessen, L. E. and T. Solhoy. 2001. Effects of experimentally increased calcium levels in the litter on terrestrial snail populations. Pedobiologia 45: 234-242.

Johnson, A. H., A. Moyer, J. E. Bedison, S. L. Richter, and S. A. Willig. 2008. Seven decades of calcium depletion in organic horizons of Adirondack forest soils. Soil Science Society of America Journal 72: 1824-1830.

Kalisz, P. J. and J. E. Powell. 2003. Effect of calcareous road dust on land snails (Gastropoda: Pulmonata) and millipedes (Diplopoda) in acid forest soils of the Daniel Boone National Forest of Kentucky, USA. Forest Ecology and Management 186: 177-183.

Knorr, M., S. D. Frey, and P. S. Curtis. 2005. Nitrogen addition and litter decomposition: A meta-analysis. Ecology 86: 3252-3257. 
Le Quere, C., R. J. Andres, T. Boden, T. Conway, R. A. Houghton, J. I House, G. Marland, G. P. Peters, G. van der Werf, A. Ahlstrom, R. M. Andrew, L. Bopp, J. G. Canadell, P. Ciais, S. C. Doney, C. Enright, P. Friedlingstein, C. Huntingford, A. K. Jain, C. Jourdain, E. Kato, R. F. Keeling, K. Klein Goldewijk, S. Levis, P. Levy, M. Lomas, B. Poulter, M. R. Raupach, J. Schwinger, S. Sitch, B. D. Stocker, N. Viovy, S. Zaehle, and N. Zeng. 2012. The global carbon budget 1959-2011. Earth System Science Data Discussions 5: 1107-1157.

Likens, G. E., C. T. Driscoll, and D. C. Busso. 1996. Long-term effects of acid rain: Response and recovery of a forest ecosystem. Science 272: 244-246.

Lucash, M. S., R. D. Yanai, J. D. Blum, and B. B. Park. 2012. Foliar nutrient concentrations related to soil sources across a range of sites in the Northeastern United States. Soil Science Society of America Journal 76: 674-683.

Magill, A. H., M. R. Downs, K. J. Nadelhoffer, R. A. Hallett, and J. D. Aber. 1996. Forest ecosystem response to four years of chronic nitrate and sulfate additions at Bear Brooks Watershed, Maine, USA. Forest Ecology and Management 84: 2937.

Magill, A. H., J. D. Aber, W. S. Currie, K. J. Nadelhoffer, M. E. Martin, W. H. McDowell, J. M. Melillo, and P. Steudlar. 2004. Ecosystem response to 15 years of chronic nitrogen additions at the Harvard Forest LTER, Massachusetts, USA. Forest Ecology and Management 196: 7-28.

Magnani, F., M. Mencuccini, M. Borghetti, P. Berbigier, F. Berninger, S. Delzon, A. Grelle, P. Hari, P. G. Jarvis, P. Kolari, A. S. Kowalski, H. Lankreijer, B. E. Law, A. Lindroth, D. Loustau, G. Manca, J. B. Moncrieff, M. Rayment, B. Tedeschi, R. Valentini, and J. Grace. 2007. The human footprint in the carbon cycle of temperate and boreal forests. Nature 447: 848-852.

May, J. D., S. B. Burdette, F. S. Gilliam, and M. B. Adams. 2005. Interspecific divergence in foliar nutrient dynamics and stem growth in a temperate forest in response to chronic nitrogen inputs. Canadian Journal of Forest Research 35: 1023-1030.

McNulty, S.G., J. Boggs, J.D. Aber, L. Rustad, and A. Magill. 2005. Red spruce ecosystem level changes following 14 years of chronic $\mathrm{N}$ fertilization. Forest Ecology and Management 219:279-291.

Miller, D. E. and S. A. Watmough. 2009. Soil acidification and foliar nutrient status of Ontario's deciduous forest in 1986 and 2005. Environmental Pollution 157: 664672. 
Nadelhoffer, K. J., J. D. Aber, and J.M. Melillo. 1985. Fine roots, net primary production and soil nitrogen availability: a new hypothesis. Ecology 66: 13701390.

Nadelhoffer, K. J., B. A. Emmett, P. Gunderson, O. J. Kjonaas, C. J. Koopmans, P. Schleppi, A. Tietema, and R. F. Wright. 1999. Nitrogen deposition makes a minor contribution to carbon sequestration in temperate forests. Nature 398: $145-148$.

Nadelhoffer, K. J. 2000. Research review: The potential effects of nitrogen deposition on fine-root production in forest ecosystems. New Phytologist 147: 131-139.

Nakamura, K. and J. Taira. 2005. Distribution of elements in the millipede, Oxidus gracilis C. L. Koch (Polydesmida: Paradoxosomatidae) and the relation to environmental habitats. BioMetals 18: 651-658.

Nakamura, K., J. Taira, and Y. Higa. 2005. Internal elements of the millipede, Chamberlinius hualienensis Wang (Polydesmida: Paradoxosomatidae). Applied Entomological Zoology 40: 283-288.

Ollinger, S. V., A. D. Richardson, M. E. Martin, D. Y. Hollinger, S. E. Frolking, P. B. Reich, L. C. Plourde, G. G. Katul, J. W. Munger, R. Oren, M. L. Smith, K. T. Paw U, P. B. Bolstad, B. D. Cook, M. C. Day, T. A. Martin, R. K. Monson, and H. P. Schmidi. 2008. Canopy nitrogen, carbon assimilation, and albedo in temperate and boreal forests: Functional relations and potential climate feedbacks. Proceedings of the National Academy of Scientists 105: 19335-19340.

Pan, Y., R. A. Birdsey, J. Fang, R. Houghton, P. E. Kauppi, W. A. Kurz, O. L. Phillips, A. Shvidenko, S. L. Lewis, J. G. Canadell, P. Ciais, R. B. Jackson, S. Pacala, A. D. McGuire, S. Piao, A. Rautiainen, S. Sitch, and D. Hayes. 2011. A large and persistent carbon sink in the world's forests. Science 333: 988-993.

Pregitzer, K. S., A. J. Burton, D. R. Zak, and A. F. Talhelm. 2008. Simulated chronic nitrogen deposition increases carbon storage in Northern temperate forests. Global Change Biology 14: 142-153.

Ramirez, K. S., J. M. Craine, and N. Fierer. 2012. Consistent effects of nitrogen amendments on soil microbial communities and processes across biomes. Global Change Biology 18: 1918-1927.

Reichle, D. E., M. H. Shanks, and D. A. Crossley. 1969. Calcium, potassium, and sodium content of forest floor arthropods. Annals of the Entomological Society of America 62: 57-62. 
Schaberg, P. G., D. H. DeHayes, and G. J. Hawley. 2001. Anthropogenic calcium depletion: a unique threat to forest ecosystem health? Ecosystem Health 7: 214228.

Schimel, D. S. 1995. Terrestrial ecosystems and the carbon cycle. Global Change Biology 1: 77-91.

Shuxia, J., Z. Wang, X. Li, Y. Sun, X. Zhang, and A. Liang. 2010. N fertilization affects on soil respiration, microbial biomass and root respiration in Larix Gmelinii and Fraxinus mandshurica plantations in China. Plant and Soil 333: 325-336.

Skeldon, M. A., M. A. Vadeboncoeur, S. P. Hamburg, and J. D. Blum. 2007. Terrestrial gastropod responses to an ecosystem level calcium manipulation in a northern hardwood forest. Canadian Journal of Zoology 85: 994-1007.

Templer, P. H., M. C. Mack, F. S. Chapin, III, L. M. Christenson, J. E. Compton, H. D. Crook, W. S. Currie, C. J. Curtis, D. B. Dail, C. M. D’Antonio, B. A. Emmett, H. E. Epstein, C. L. Goodale, P. Gundersen, S. E. Hobbie, K. Holland, D. U. Hooper, B. A. Hungate, S. Lamontagne, K. J. Knadelhoffer, C. W. Osenberg, S. S. Perakis, P. Schleppi, J. Schimel, I. K. Schmidt, M. Sommerkorn, J. Spoelstra, A. Tietema, W. W. Wessel, and D. R. Zak. 2012. Sinks for nitrogen inputs in terrestrial ecosystems: a meta-analysis of ${ }^{15} \mathrm{~N}$ tracer field studies. Ecology 93: 1816-1829.

Thomas, R. Q., C. D. Canham, K. C. Weathers, and C. L. Goodale. 2010. Increased tree carbon storage in response to nitrogen deposition in the US. Nature Geoscience 3: $13-17$.

Tilman, D. 1993. Species richness of experimental productivity gradients: How important is colonization limitation? Ecology 74: 2179-2191.

United States Environmental Protection Agency. 2013. CASTNet 2011 annual report. AMEC Environment and Infrastructure, Inc., Washington, DC.

Vitousek, P. M., J. D. Aber, R. W. Howarth, G. E. Likens, P. A. Matson, D. W. Schindler, W. H. Schlesinger, and D. G. Tilman. 1997. Human alteration of the global nitrogen cycle: sources and consequences. Ecological Applications 7: 737-750.

Wallace, Z. P., G. M. Lovett, J. E. Hart, and B. Machona. 2007. Effects of nitrogen saturation on tree growth and death in a mixed-oak forest. Forest Ecology and Management 243: 210-218.

Whittinghill, K. A., W. S. Currie, D. R. Zak, A. J. Burton, and K. S. Pregitzer. 2012. Anthropogenic $\mathrm{N}$ deposition increases soil $\mathrm{C}$ storage by decreasing the extent of litter decay: Analysis of field observations with an ecosystem model.

Ecosystems 15: 450-461. 
Chapter 2. Will more nitrogen enhance carbon storage in young forest stands in central Appalachia? 


\subsection{Abstract.}

Many temperate deciduous forests in the Eastern US are young and have experienced decades of elevated inputs of acidic compounds and biologically available nitrogen (N) from the atmosphere. These young forests play an important role in the global carbon (C) cycle as $\mathrm{C}$ sinks, and it is possible that acidic deposition will influence the strength of this sink. I used the Fernow Experimental Forest Long Term Soil Productivity (LTSP) experiment near Parsons, WV to evaluate how 13 years of experimental $\mathrm{N}$ additions has affected total ecosystem $\mathrm{C}$ storage and stand level dynamics in a young temperate deciduous forest. Specifically I examined whether N additions: 1) directly increased aboveground growth of regenerating trees but did so in a way that was independent of the indirect effects of soil acidification; 2) directly (independent of acidification effects) increased forest floor and soil $\mathrm{C}$ pools, and decreased the fine root $\mathrm{C}$ pool; and 3) lowered stand density and diversity. I also tested whether tree species were differentially affected by either $\mathrm{N}$ fertilization or soil acidification.

Thirteen years of ammonium sulfate additions to a regenerating deciduous forest stimulated $\mathrm{C}$ storage by $22 \%$ - even in a region with historically high levels of atmospheric $\mathrm{N}$ deposition. This response was driven primarily by a $27 \%$ increase in $\mathrm{C}$ storage in aboveground biomass and to a lesser extent by a $35 \%$ increase in $\mathrm{C}$ stored in the forest floor. Despite the dominance of a single tree species (Prunus pensylvanica), the overall response was a complex mixture of species-specific changes in the growth of individuals, that may have been tempered by changes in stand density. Indirect effects of $\mathrm{N}$ additions that could be mitigated by lime additions were found to increase $\mathrm{C}$ accumulation in the forest floor as well as decrease the number of tree species.

In the short-term it is likely that acidic deposition will stimulate forest growth and $\mathrm{C}$ storage in young temperate deciduous forests. However, given the differential responses observed for longer-lived tree species versus the positive response for short-lived species, it appears that the long-term effects of $\mathrm{N}$ deposition on $\mathrm{C}$ storage in temperate deciduous forests may be different than the short term effects and may even be negative. 


\subsection{Introduction.}

The residual terrestrial carbon (C) sink is the implied uptake by terrestrial ecosystems of the $\sim 28 \%(\sim 2.6 \mathrm{Pg} \mathrm{C} / \mathrm{yr})$ of anthropogenic carbon dioxide $\left(\mathrm{CO}_{2}\right)$ emissions that cannot be accounted for by atmospheric accumulation or oceanic uptake (Houghton et al., 1998; Pan et al., 2011; Le Quere et al., 2012). A better understanding of the factors responsible for the terrestrial residual $\mathrm{C}$ sink will enable scientists to more effectively incorporate it into models and quantify how it may vary as a function of time or other changing variables including climate or soil conditions. Currently we think that a portion of this residual $\mathrm{C}$ uptake occurs on land in the northern temperate latitudes (Ciais et al., 1995). Furthermore, forests in these latitudes, such as those in the Appalachian Mountains of Eastern US, may be responsible for a large portion of the sink (Schimel, 1995; Pan et al., 2011).

Several mechanisms have been proposed for the creation and maintenance of a temperate forest $\mathrm{C}$ sink. Increased forest growth following logging and abandoning of agricultural land, as well as the maintenance of young, regrowing forests by various silvicultural practices have been implicated as primary contributors to the enhanced $\mathrm{C}$ uptake (Goodale et al., 2002). Increased tree growth in response to increasing levels of atmospheric $\mathrm{CO}_{2}$ may also be responsible for a portion of the $\mathrm{C}$ sink (Ainsworth and Long, 2005). Similarly, a fertilization effect from the biologically available nitrogen (N) in acidic deposition may have increased growth of N-limited forest trees (Aber and Driscoll, 1997; Thomas et al., 2010). 
The link between the residual terrestrial $\mathrm{C}$ sink and acidic deposition in temperate deciduous forests of Eastern US is important to our understanding of the current global C cycle and how humans affect it. This link is, however, complex and not completely understood.

Acidic deposition supplies ecosystems with biologically available forms of $\mathrm{N}$ at rates that are substantially greater than pre-industrial background levels (Galloway et al., 1976; Galloway et al., 1987). Despite recent reductions in acid deposition in the eastern US due to the Clean Air Act, the levels of $\mathrm{N}$ in precipitation in this region are still above preindustrial background levels and likely will remain elevated for some time. Additionally, in other temperate forests, especially in Asia, levels of $\mathrm{N}$ deposition are likely to continue to rise in the future (Galloway et al., 2004). Acidic deposition as a factor in the residual terrestrial $\mathrm{C}$ sink is more complex than forest regrowth or $\mathrm{CO}_{2}$ fertilization, though, because short-term benefits such as the alleviation of $\mathrm{N}$ limitation could be diminished, or reversed, by longer-term effects such as the depletion of base cations, lower soil $\mathrm{pH}$, and higher levels of toxic aluminum $\left(\mathrm{Al}^{3+}\right)$ (Aber et al., 1998).

In the last twenty years there has been a great deal of research on the effect of $\mathrm{N}$ deposition on forest C storage, and results vary. Modeling studies (Aber and Driscoll, 1997) and $\mathrm{N}$ addition experiments (Magill et al., 2004; Pregitzer et al., 2008), as well as more complex analyses combining models and field measurements (Magnani et al., 2007; Ollinger et al., 2008), have provided evidence that $\mathrm{N}$ deposition is at least in part 
responsible for an enhanced terrestrial C sink - some of which occurs in forest soils. However, ${ }^{15} \mathrm{~N}$ tracer studies (Nadelhoffer et al., 1999; Templer et al., 2012) have questioned the likelihood of an increase in aboveground $\mathrm{C}$ storage due to elevated $\mathrm{N}$ inputs. Additionally, some field studies (Boggs et al., 2005; Magill et al., 1996) have shown a neutral or mixed response to $\mathrm{N}$ inputs, and some (McNulty et al., 2005; Elias et al., 2009; May et al., 2005) have even shown declines in forest growth due to $\mathrm{N}$ inputs. This range of results is likely due to the complex and non-linear responses that can develop during chronic acidification and their dependence on forest history and soil characteristics.

The timing of a shift from a positive to a negative response in aboveground tree $\mathrm{C}$ storage due to elevated $\mathrm{N}$ inputs may vary with forest type, land-use history, and soil properties. In general, it appears that coniferous forests are more sensitive to enhanced $\mathrm{N}$ inputs than deciduous forests (Aber et al., 1998; Magill et al., 2004) and older forests are less likely to utilize $\mathrm{N}$ inputs than young, fast-growing forests (Vitousek and Reiners, 1975; Fenn et al., 1998). A further complication is the likelihood that once $\mathrm{N}$ availability exceeds biological demand ( $\mathrm{N}$ saturation), different soils will be more, or less, resilient to leaching of calcium $\left(\mathrm{Ca}^{2+}\right)$ and magnesium $\left(\mathrm{Mg}^{2+}\right)$ and soil acidification. Specifically, trees growing in soils derived from predominantly sandstone parent materials will probably be more susceptible to negative effects more quickly than those growing on soils derived from limestone containing parent material. Susceptible soils contain relatively low amounts of $\mathrm{Ca}$ and $\mathrm{Mg}$ and losses are not replaced quickly through weathering (Likens et al., 1996). Furthermore, numerous temperate deciduous forests of 
the Eastern US are not only underlain by acidic, sandstone-derived soils but have experienced a significant amount of timber harvest which can permanently remove large quantities of nutrient cations (Federer et al., 1989; Adams et al., 2000). Thus, many forests in the Eastern US should be able to retain N due to a positive response in tree growth. However, once $\mathrm{N}$ saturation develops, the negative effects could come relatively quickly and be hard to reverse.

In addition to the direct positive or negative changes on tree growth induced by chronically elevated $\mathrm{N}$ deposition, it is also possible that elevated $\mathrm{N}$ deposition could result in long-lived alterations in forest $\mathrm{C}$ sequestration by changing stand dynamics or species composition. Little research has focused on the effect of $\mathrm{N}$ inputs on stand-level changes in regenerating forests where differential species responses to nutrient level changes could alter competitive relationships and community structure in later successional stages (Adams, 2003). However, work in old fields (Henry et al., 1999), and in grasslands and heathlands (Vitousek et al., 1997; Tilman, 1993) demonstrated that elevated $\mathrm{N}$ inputs can significantly change community level variables and lead to lower diversity. Research in temperate deciduous forests using a $\mathrm{N}$ deposition gradient (Boggs et al., 2005), forest inventory data (Thomas et al., 2010), and watershed fertilization (May et al., 2005; DeWalle et al., 2006) has shown that different tree species respond differently to elevated N. Also, more fertile sites have accelerated self-thinning resulting in fewer, larger trees than less fertile sites (Henry et al., 1999). It therefore seems likely that, given enough time, acidic deposition will change stand dynamics and/or tree species 
composition in temperate deciduous forests in ways that could alter their capacity to sequester atmospheric $\mathrm{C}$.

Although aboveground growth in temperate deciduous forests is often considered to be responsive to $\mathrm{N}$ additions, increasing $\mathrm{N}$ inputs can also alter belowground processes. For example, it has been observed that increased $\mathrm{N}$ availability in forests is associated with reduced fine root biomass and the amount of $\mathrm{C}$ stored in this pool (Nadelhoffer et al., 1985; Nadelhoffer, 2000; Shuxia et al., 2010). N inputs may also affect the composition of the soil microbial community and the expression of extracellular enzymes in ways that enhance C storage in the litter layer (Fog, 1988; DeForest et al., 2005; Knorr et al., 2005; Zak et al., 2008) and soil (Ramirez et al., 2012; Whittinghill et al., 2012) of forests. Thus, the total response of the temperate deciduous forest $\mathrm{C}$ sink to $\mathrm{N}$ deposition will be the sum of both the above- and belowground pool responses.

The Fernow Experimental Forest Long Term Soil Productivity Experiment (LTSP) near Parsons, WV provides a unique opportunity to evaluate how 13 years of experimental N additions, and associated soil acidification, have affected total ecosystem $\mathrm{C}$ storage and stand level dynamics in a young regrowing temperate deciduous forest. Using this experiment I was able to test several hypotheses based on our current understanding of how $\mathrm{N}$ additions alter the ability of forests to sequester C. Specifically I examined whether $\mathrm{N}$ additions: 1) directly increased aboveground growth of regenerating trees but did so in a way that was independent of the indirect effects of acidification (e.g., loss of nutrient cations, lower soil $\mathrm{pH}$, and/or elevated $\mathrm{Al}^{3+}$ ); 2) directly (independent of 
acidification effects) enhanced forest floor and soil C pools, and lowered the fine root $\mathrm{C}$ pool; and 3) lowered stand density and diversity. I also examined whether tree species were differentially affected by either $\mathrm{N}$ fertilization or soil acidification.

\subsection{Methods.}

This study was done in the Fernow Experimental Forest Long Term Soil Productivity

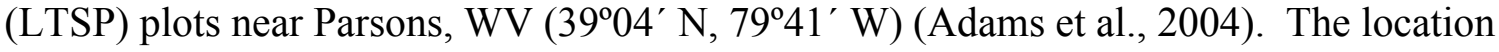
of the Fernow LTSP experiment has a SE aspect, and slopes between 15 and 31\%. It is situated in the Allegheny Mountain subsection of the Appalachian Physiographic Province and has an elevation range of $798-847 \mathrm{~m}$. Prior to the initiation of the experiment in 1996, the most recent logging activity occurred in $\sim 1910$, and most trees were $\sim 85$ years old. The forest community before the experiment started was classified as a central Appalachian mixed hardwood forest.

The Fernow LTSP experiment is a randomized block design containing four blocks each with four plots that receive different treatments (Fig. 2.1). Each treatment plot is 0.4 ha in size ( $60.9 \mathrm{~m}$ on a side) and includes a 7.6-m wide buffer strip in which no samples were collected. The sampled area in each plot (referred to as a "growth plot") is 0.2 ha in area. When the plots were established, a numbered grid of permanent stakes was added to facilitate plot location and consistent sampling (Adams et al., 2004). 
The four treatments in the Fernow LTSP study are: (1) reference plots (UNCUT ) that were last harvested around 1910, and that received no experimental manipulation as part of the Fernow LTSP study; (2) cut plots (WT) that were subjected to a whole-tree harvest in 1996 in which all aboveground biomass was removed; (3) cut and fertilized plots (WT+NS) that were whole-tree harvested in 1996 and since that time have received annual applications of $35 \mathrm{~kg} \mathrm{~N} / \mathrm{ha}$ as ammonium sulfate to enhance $\mathrm{N}$ inputs and accelerate soil acidification; and (4) cut, fertilized, and limed plots (WT+NS+LIME) that were treated the same as the $\mathrm{WT}+\mathrm{NS}$ plots and that have also received dolomitic lime every other year at an annual rate of $22.5 \mathrm{~kg} \mathrm{Ca} / \mathrm{ha}$ and $11.6 \mathrm{~kg} \mathrm{Mg} / \mathrm{ha}$ since the initiation of the study. Ambient inputs of $\mathrm{NH}_{4}{ }^{+}, \mathrm{NO}_{3}{ }^{-}$, and $\mathrm{SO}_{4}{ }^{2-}$ for 1996 at a nearby weather station were $2.83 \mathrm{~kg} \mathrm{~N} / \mathrm{ha}, 5.26 \mathrm{~kg} \mathrm{~N} / \mathrm{ha}$, and $10.7 \mathrm{~kg} \mathrm{~S} / \mathrm{ha}$, respectively (NADP, 2000). By 2008, ambient inputs of $\mathrm{NH}_{4}{ }^{+}, \mathrm{NO}_{3}{ }^{-}$, and $\mathrm{SO}_{4}{ }^{2-}$ at the same weather station had fallen to $2.27 \mathrm{~kg} \mathrm{~N} / \mathrm{ha}, 2.56 \mathrm{~kg} \mathrm{~N} / \mathrm{ha}$, and $6.16 \mathrm{~kg} \mathrm{~S} / \mathrm{ha}$, respectively (NADP, 2009).

In this study, I only considered the harvested plots (WT, WT+NS, and WT+NS+LIME) because I was concerned with the effects of acidic deposition on an aggrading forest as well as separating the $\mathrm{N}$ response from the acidity response. All of these treatment plots underwent a whole tree harvest in 1996 (which was the second major logging event for the forest) and were allowed to regenerate naturally. These plots are also located on soils derived from base poor parent materials and in a region with a history of acidic deposition and logging. Soils are classified as loamy-skeletal, mixed active, mesic typic Dystrudepts and the parent materials are sandstone colluvium, sandstone residuum, and weathered shale (Adams et al., 2004). I included plots receiving lime additions because 
liming should mitigate the negative effects of acidification and allow me a unique opportunity to distinguish the direct effects of $\mathrm{N}$ inputs from the indirect effects of soil acidification caused by fertilizer additions.

To estimate and compare the ecosystem C storage in these regrowing forests, I measured the $\mathrm{C}$ pools in aboveground tree biomass, litterfall, the forest floor, mineral soil, and fine roots after 13 years of experimental treatments. All measurements were taken in summer of 2009, except for litterfall, which was measured in autumn of 2009.

To determine the effect of the treatments on $\mathrm{C}$ storage in aboveground tree biomass, I measured diameter at breast height (DBH) of 3,278 live trees, noted the species, and used species-specific allometric equations to estimate tree biomass. To sample trees in the various treatments, I divided each plot into twelve squares of known area, randomly selected six of those squares, and recorded the DBH and species of all trees within the area of the square (Fig. 2.1). Converting DBH to biomass was done following Johnson et al. (2010). For each tree, I used Fernow-specific parameters, or parameters based on Brenneman et al. (1978), in the following allometric equation: biomass $=a(D B H)^{b}$. Biomass estimates for each tree were then used to calculate aboveground $\mathrm{C}$ pools by assuming that biomass had a $50 \% \mathrm{C}$ content.

I sampled the forest floor in each plot of the Fernow LTSP to try to detect a response of forest floor $\mathrm{C}$ content to the treatments. I chose sampling locations by dividing each plot into 192 squares and randomly choosing 12 squares per plot (Fig. 2.1). The center of 
each chosen square was located and the entire forest floor $\left(\mathrm{O}_{\mathrm{i}}, \mathrm{O}_{\mathrm{e}}\right.$, and $\left.\mathrm{O}_{\mathrm{a}}\right)$ was collected from a $10 \times 10 \mathrm{~cm}$ area. Samples were dried $\left(65^{\circ} \mathrm{C}\right.$ for $>48$ hours $)$, weighed, ground, and analyzed for C concentration by Dumas combustion (Nelson and Sommers, 1982) using a Carlo Erba NA 1500 N,C,S elemental analyzer. I then calculated the average forest floor $\mathrm{C}$ content per unit area for each plot by using the $\mathrm{C}$ content and mass of the forest floor samples.

Litterfall was also measured to assess if any treatment differences in the forest floor mass might be attributable to treatment effects on the input of litter. I placed 5 plastic laundry baskets measuring $35.5 \times 52 \mathrm{~cm}$ as litter collectors per plot. I anchored the litter collectors securely to the permanent growth plot stakes and randomly chose 5 of the 20 possible stakes for use (Fig. 2.1). The collectors were placed in the field before leaves began to fall in autumn, and a single collection of leaves was made when all leaves had fallen. All baskets had small drainage holes drilled in the bottom; and leaves from each collector were dried $\left(65^{\circ} \mathrm{C}\right.$ for $>48$ hours), weighed, and the average mass of litterfall per unit area was calculated for each plot.

I collected and analyzed soil samples to determine the effect of the treatments on the soil $\mathrm{C}$ pool. Soil cores that were $2.3 \mathrm{~cm}$ in diameter and $5 \mathrm{~cm}$ long were collected at 16 locations per plot, selected by dividing the plot into 192 squares and randomly choosing 16 (Fig. 2.1). At each location, the top $5 \mathrm{~cm}$ of the A horizon was sampled, discarding the $\mathrm{O}$ horizon. The soil cores were dried $\left(65^{\circ} \mathrm{C}\right.$ for $>48$ hours $)$, ground, and analyzed for C concentration using a Carlo Erba NA 1500 N,C,S elemental analyzer. The average soil 
$\mathrm{C}$ mass per unit area in the top $5 \mathrm{~cm}$ of soil was then calculated using the $\mathrm{C}$ content values and reported soil bulk density values from Adams et al. (2004).

I also measured the effect of treatments on the fine root $(<2 \mathrm{~mm}$ diameter $) \mathrm{C}$ pool by collecting soil cores from each plot in the Fernow LTSP and sorting out and analyzing the roots. I collected 15 soil cores per plot, each $4.5 \mathrm{~cm}$ in diameter and $10 \mathrm{~cm}$ long, by dividing the plots into 192 squares and randomly choosing 5 locations where I collected 3 cores (Fig. 2.1). All fine roots from each soil core were carefully removed by the same person in the lab. The roots were then $\operatorname{dried}\left(65^{\circ} \mathrm{C}\right.$ for $>48$ hours), weighed, ground, and analyzed for $\mathrm{C}$ concentration following the same procedure used for forest floor and mineral soil samples. Total fine root $\mathrm{C}$ in the top $10 \mathrm{~cm}$ of soil per unit area was then calculated for each sample and averaged per plot.

The species census data collected during the aboveground tree biomass estimation was also used to compare community diversity and composition, and to look for speciesspecific effects of the treatments. Shannon's Index (SI) of diversity was calculated for each plot. The relative importance value (RIV), an average of the relative basal area and relative abundance for each species, was calculated for all plots and for each plot separately. Finally, the average size of individual trees and the number of trees per unit area were calculated for all species and for each species separately.

I used analysis of variance (ANOVA) to determine if increasing $\mathrm{N}$ inputs altered the amount of $\mathrm{C}$ stored in various pools of an aggrading temperate deciduous forest. For 
each variable measured, I set up a two-way ANOVA with the main factors being treatment and block (no treatment*block interaction term was included due to lack of replication at this level). Each plot was a single replicate and the average value for each variable was used for each plot, thus $n=4$. If significant effects of either factor were found, then post hoc Tukey-Kramer tests were run. In order to test whether the effect of treatment depended on species, I set up an additional ANOVA for the dependent variables biomass per tree, tree density, and RIV including species as a factor with the four most common species being considered. In this ANOVA, I included treatment, species, block, and treatment*species as effects. An alpha level of 0.05 was used throughout to assess statistical significance and $p$ values less than 0.1 were considered trends. Assumptions of ANOVA, including normality of residuals and homogeneity of variances were tested, and any necessary transformations were performed. All statistical tests were performed using SAS JMP version 10 (JMP).

\subsection{Results.}

After 13 years of continuous treatment, I found that total measured C storage (aboveground + forest floor + fine roots + mineral soil) in a regrowing temperate deciduous forest was greater in plots receiving additions of ammonium sulfate (Fig. 2.2). Total measured C storage was $22 \%$ higher in $\mathrm{WT}+\mathrm{NS}$ plots and $18 \%$ higher in $\mathrm{WT}+\mathrm{NS}+$ LIME plots $(\mathrm{p}=0.017)$. These differences correspond to $1,140 \mathrm{more} \mathrm{g} \mathrm{C} / \mathrm{m}^{2}$ in the WT+NS treatment and 950 more $\mathrm{g} \mathrm{C} / \mathrm{m}^{2}$ in the WT+NS+LIME treatment relative to the WT treatment. If we consider the total amount of $\mathrm{N}$ added across the duration of the 
treatments, then the WT+NS treatment resulted in an additional C sequestration of $25 \mathrm{~g}$ $\mathrm{C} / \mathrm{g} \mathrm{N}$ added and the WT+NS+LIME treatment resulted in an additional $\mathrm{C}$ sequestration of $21 \mathrm{~g} \mathrm{C} / \mathrm{g} \mathrm{N}$ added.

The greater $\mathrm{C}$ storage in plots receiving ammonium sulfate was driven by higher aboveground tree biomass $\mathrm{C}(\mathrm{p}=0.045)$ and a higher forest floor $\mathrm{C}$ content $(\mathrm{p}=0.001)$. There were no significant changes in fine root $\mathrm{C}$ pools $(\mathrm{p}=0.375)$ or soil $\mathrm{C}$ pools $(\mathrm{p}=0.282)($ Fig. 2.3). The aboveground tree biomass was $27 \%$ greater in the WT+NS and $25 \%$ greater in the WT+NS+LIME plots when compared to WT plots (Fig. 2.3). The C pool in the forest floor was 35\% greater in the WT+NS plots (Fig. 2.3).

I estimate that aboveground tree biomass stored a total of $3.04 \mathrm{~kg} \mathrm{C} / \mathrm{m}^{2}\left(234 \mathrm{~g} \mathrm{C} / \mathrm{m}^{2} / \mathrm{yr}\right)$ in the WT treatment plots, $3.87 \mathrm{~kg} \mathrm{C} / \mathrm{m}^{2}\left(298 \mathrm{~g} \mathrm{C} / \mathrm{m}^{2} / \mathrm{yr}\right)$ in the WT+NS plots, and 3.82 $\mathrm{kg} \mathrm{C} / \mathrm{m}^{2}\left(294 \mathrm{~g} \mathrm{C} / \mathrm{m}^{2} / \mathrm{yr}\right)$ in the WT+NS+LIME plots (Fig. 2.3). When compared to the WT treatment, the change in C storage in aboveground tree biomass due to the WT $+\mathrm{NS}$ treatment was $0.83 \mathrm{~kg} \mathrm{C} / \mathrm{m}^{2}$ or $18 \mathrm{~g} \mathrm{C} / \mathrm{g} \mathrm{N}$ added, and that for the WT+NS+LIME treatment was $0.78 \mathrm{~g} \mathrm{C} / \mathrm{m}^{2}$ or $17 \mathrm{~g} \mathrm{C} / \mathrm{g} \mathrm{N}$. Using a $50 \%$ conversion factor, values for biomass would be twice those for $\mathrm{C}$.

The greater response of $\mathrm{C}$ storage in aboveground tree biomass to additions of ammonium sulfate was the net effect of a greater average size of individual trees $(p=0.006)$ that may have been partially offset by an undetectable reduction in tree density $(\mathrm{p}=0.143)($ Fig 2.4). The average tree size was $62 \%$ greater in the WT+NS and $73 \%$ 
greater in the WT+NS+LIME plots when compared to WT plots. Estimates of tree densities were $0.67,0.53$, and $0.50 \mathrm{stems} / \mathrm{m}^{2}$ for the WT, WT+NS, and WT+NS+LIME plots, respectively. There was no change due to treatment in the mass of autumn litterfall, which ranged from 0.22 to $0.24 \mathrm{~kg} / \mathrm{m}^{2} / \mathrm{yr}(\mathrm{p}=0.744)$.

With respect to tree species composition, there were 21 different species encountered, 4 of which accounted for more than 5\% each of the total RIV (Table 2.1). These species were Prunus pensylvanica (PRPE), Liriodendron tulipifera (LITU), Betula lenta (BELE), and Prunus serotina (PRSE). Prunus pensylvanica was by far the most dominant tree in the LTSP plots, with $51.9 \%$ of the total RIV. At the scale of the total area sampled in each plot (6 "squares" per plot $x 81 \mathrm{~m}^{2}$ per square $=0.486$ ha per plot), the species richness of live trees was significantly lower in the WT+NS treatment which had $\sim 2$ fewer species than the WT and WT+NS+LIME plots $(\mathrm{p}=0.016)($ Fig 2.5). Two species that were absent only in the WT+NS plots were Acer saccharum (ACSA) and Quercus prinus (QUPR). However, there was no change in tree diversity as measured by Shannon's Index due to the treatments $(p=0.893)$. Shannon's index values ranged from 1.57 to 1.68 .

The effect of treatment on biomass per tree depended on species when the four species which each made up more than 5\% of the total RIV (PRPE, LITU, BELE, and PRSE) were considered $(\mathrm{p}=0.044)$ (Fig 2.6). While the slope of the PRPE and PRSE biomass responses to $\mathrm{N}$ additions were positive, LITU and BELE had a negative or neutral response to $\mathrm{N}$ additions (Fig 2.6). When only these four species were considered, the 
treatment effect on biomass per tree was no longer detectable $(\mathrm{p}=0.177)$. There was also an effect of species on biomass of individual trees $(\mathrm{p}<0.0001)$, with PRPE having about three times greater biomass per tree than the other species which were not different from one another. For both tree density and RIV, the effect of treatment did not depend on species $(\mathrm{p}=0.829, \mathrm{p}=0.387$, respectively). There was no detectable treatment effect on RIV ( $p=0.194)$, but a trend toward a decrease in tree density of the four most dominant species due to ammonium sulfate addition $(\mathrm{p}=0.058)$. Both tree density and RIV differed by species, however, with PRPE having larger values than the other species, which did not differ from one another $(\mathrm{p}=0.001, \mathrm{p}<0.0001$, respectively). There were over twice as many PRPE trees per area as the other three species, and PRPE accounted for about five times as much of the RIV as the other species.

The only statistical model for which there were significant deviations from a normal distribution for residuals was the model including species as a factor and having individual tree biomass as a dependent variable. In this case, a log transformation resulted in a distribution of residuals which was not significantly different from normal, and statistics were done on the log transformed data. I found block effects to be significant only for soil $\mathrm{C}$ pools $(\mathrm{p}=0.017)$. Block 1 had significantly higher $\mathrm{C}$ content than Block 4, neither of which differed from Blocks 2 or 3. 


\subsection{Discussion.}

Fertilization with ammonium sulfate resulted in an increased input of both bioavailable $\mathrm{N}$ and S. In this study, I interpreted any changes due solely to ammonium sulfate additions to be only a consequence of enhanced $\mathrm{N}$, rather than enhanced $\mathrm{S}$ availability. I felt that this was reasonable and parsimonious because: (1) $\mathrm{N}$ is present at much greater levels than $\mathrm{S}$ in temperate deciduous forest trees (Vitousek et al., 1988); (2) the lack of available $\mathrm{N}$ often limits, or co-limits, growth in terrestrial forests (Le Bauer and Tresseder, 2008; Elser et al., 2007; Reich et al., 1997); (3) in regions with elevated S deposition (such as West Virginia), atmospheric S inputs exceed forest S requirements (Vitousek et al., 1988); and (4) a previous fertilization experiment at the Fernow Experimental Forest found that mature trees were N limited in 1970 (Auchmoody and Smith, 1977).

Overall, the results from this study supported the hypothesis that additional inputs of $\mathrm{N}$ to a young forest can, at least initially, enhance $\mathrm{C}$ sequestration by stimulating $\mathrm{C}$ storage in aboveground tree growth and in the forest floor-even for a forest located in a region with historically high levels of atmospheric $\mathrm{N}$ deposition. Treatment comparisons further suggested that enhanced storage in aboveground biomass was a direct result of $\mathrm{N}$ on tree growth, whereas enhanced $\mathrm{C}$ storage in the forest floor resulted from indirect effects of $\mathrm{N}$ addition on soil acidity or other factors that could be mitigated by lime additions (e.g. loss of nutrient cations and/or elevated $\mathrm{Al}^{3+}$ ). In contrast to my expectations, $\mathrm{N}$ additions (either with or without lime) did not significantly alter the amount of $\mathrm{C}$ in fine roots in a year with precipitation equal to the 50 -year average or the $\mathrm{C}$ content in the upper $5 \mathrm{~cm}$ of mineral soil. 
Quantitatively, the average enhancement rate of C storage in aboveground tree biomass between 1996 and 2009 was $\sim 60-64 \mathrm{~g} \mathrm{C} / \mathrm{m}^{2} / \mathrm{yr}(\sim 17 \mathrm{~g} \mathrm{C} / \mathrm{g} \mathrm{N})$, similar to rates $(\sim 50 \mathrm{~g}$ $\mathrm{C} / \mathrm{m}^{2} / \mathrm{yr}$ ) reported for a hardwood forest in Michigan after 10 years of $\mathrm{N}$ fertilization with $30 \mathrm{~kg} \mathrm{~N} / \mathrm{ha} / \mathrm{yr}$ as $\mathrm{NH}_{4} \mathrm{NO}_{3}$ (Pregitzer et al., 2008). Furthermore, these results were qualitatively consistent with other studies of hardwood forests in Massachusetts (Magill et al. 2004), Wisconsin (Nadelhoffer et al., 1985), and throughout the Eastern US (Thomas et al., 2010) that all reported a stimulation of forest tree growth due to $\mathrm{N}$ addition or greater soil $\mathrm{N}$ availability - although the magnitude of change reported in these studies varies widely from $\sim 5 \mathrm{~g} \mathrm{C} / \mathrm{g} \mathrm{N}$ in Massachusetts to $\sim 61 \mathrm{~g} \mathrm{C} / \mathrm{g} \mathrm{N}$ for forests throughout the Eastern US.

A greater $\mathrm{C}$ storage in the forest floor in response to additions of only ammonium sulfate, combined with the lack of any difference in litterfall mass, suggested a reduction in litter decomposition in the WT+NS plots. This result was consistent with slower litter decay rates measured in a nearby watershed (WS 3) that has received ammonium sulfate additions in the same amount as the Fernow LTSP experiment since 1989 (Adams and Angradi, 1996). However, a unique insight from this study was that the treatmentinduced change in the amount of forest floor $\mathrm{C}$ disappeared when lime was added along with ammonium sulfate (WT+NS+LIME plots). This liming effect provided evidence that changes in litter decay could result from soil acidification rather than a direct effect of $\mathrm{N}$ additions alone. And since other studies reporting a reduction in forest floor decomposition with $\mathrm{N}$ addition did not have a liming treatment (Hobbie, 2008; Magill 
and Aber, 1998; Pregitzer et al., 2008), it is possible that at least some of their results were an indirect effect of $\mathrm{N}$ addition due to soil acidification.

In contrast with the results from several other studies, I did not detect lower amounts of fine root biomass (Nadelhoffer et al., 1985; Nadelhoffer, 2000) or elevated levels of C in the upper $5 \mathrm{~cm}$ of mineral soil (Edwards et al., 2011; Pregitzer et al., 2008). However, a study of chronic additions of ammonium sulfate to a more mature forest in a nearby watershed (WS 3 last cut in 1970) suggested that the expected differences in both fine roots and soil $\mathrm{C}$ may emerge in time. A recent comparison (Peterjohn, unpublished data) between WS 3 and an adjacent, unfertilized forest of similar age (WS 7) found that the fertilized forest (WS 3$)$ had $\sim 50 \%$ fewer fine roots to a depth of $15 \mathrm{~cm}(\sim 150 \mathrm{vs.} \sim 300$ $\mathrm{g} / \mathrm{m}^{2}$ ), and although the soil C pools in the upper $5 \mathrm{~cm}$ of mineral soil in WS 3 were not significantly greater $(\mathrm{p}=0.141)$, the $\mathrm{C}$ concentrations were $(\sim 5.8$ vs. $\sim 5.3 \% \mathrm{C} ; \mathrm{p}=0.047)$. Other fertilization studies in older, more mature forests (Edwards et al., 2011; Pregitzer et al., 2008) have also detected increases in soil $\mathrm{C}$ pools as a result of $\mathrm{N}$ additions. Coarse root $\mathrm{C}$ pools were not estimated, leading to an underestimation of the total $\mathrm{C}$ pools, but allometric equations are not available for determining coarse root biomass from $\mathrm{DBH}$, and direct measurement of coarse roots was not possible.

My estimate of forest $\mathrm{C}$ storage (aboveground + roots + soils) per unit of $\mathrm{N}$ input $(\sim 21-25$ g C/g N) fell below other estimates. For example, Erisman et al. (2011) reviewed studies of total $\mathrm{C}$ storage in forests and heathlands and found a range of 35-65 $\mathrm{g} \mathrm{C} / \mathrm{g} \mathrm{N}$. Earlier reviews (Reay et al., 2008; Liu and Greaver, 2009) estimated that C storage responses to 
$\mathrm{N}$ addition fall in the range of 40-200 $\mathrm{g} \mathrm{C} / \mathrm{g} \mathrm{N}$ added. However, the $200 \mathrm{~g} \mathrm{C} / \mathrm{g} \mathrm{N}$ added value (Magnani et al., 2007) has been questioned and is now considered to fall in the range of 30-75 g C/g N added range (DeVries et al., 2008; Sutton et al., 2008), still well above my estimate. Low values of total $\mathrm{C}$ storage per unit of $\mathrm{N}$ input for our experiment, and for any fertilization experiment using large $\mathrm{N}$ additions relative to ambient inputs, are understandable since the photosynthetic capacity and increment growth of forest trees are known to saturate above a certain amount of N addition (Fleischer et al., 2013; Mitchell and Chandler, 1939). Thus, especially in regions with high amounts of background $\mathrm{N}$ deposition, comparisons of unfertilized forests to those receiving high doses of added $\mathrm{N}$ should yield a conservative estimate of $\mathrm{C}$ storage per unit of $\mathrm{N}$ addition.

Interestingly, if values for $\mathrm{C}$ storage efficiency are assumed to be constant over the range of actual atmospheric $\mathrm{N}$ deposition (e.g. Thomas et al., 2011), then recent declines in $\mathrm{N}$ emissions (Kim et al., 2006) and deposition (Burns et al., 2011) observed in the Eastern US due to the Clean Air Act should have diminished this region's contribution to the terrestrial $\mathrm{C}$ sink. Likewise any reductions of $\mathrm{N}$ deposition in Europe that result from the Gothenburg protocol should also diminish the terrestrial C sink in forests of that region, and the majority of the $\mathrm{N}$-stimulated $\mathrm{C}$ sink in temperate forests is likely to shift towards Asia where $\mathrm{N}$ deposition most likely will continue to increase for the foreseeable future (Dentener et al., 2006). More generally, if actions were taken to lower the impacts of acid deposition and $\mathrm{N}$ saturation at a global scale, then one undesirable consequence might be a diminished terrestrial $\mathrm{C}$ sink, and a resultant increase in the atmospheric fraction of $\mathrm{CO}_{2}$ emissions from human activities. 
Among the more long-lasting impacts of enhanced $\mathrm{N}$ inputs to forest ecosystems can be changes in the structure, composition, and diversity of forest trees. Regarding changes in stand structure, it was interesting to note that the $\sim 66 \%$ increase in the amount of $\mathrm{C}$ stored in the wood of individual trees due to $\mathrm{N}$ additions (Fig. 2.4) may have been partially offset by an undetectable difference stand density, resulting in only a $\sim 33 \%$ increase in the amount of $\mathrm{C}$ stored in the wood on a per unit area basis (Fig. 2.3a with assumption of wood being $50 \% \mathrm{C}$ ). This offset indicates that measurements made on an individual tree basis could be misleading and could inflate estimates of $\mathrm{C}$ storage actually realized on a per area basis due to stand-level changes. The acceleration of self-thinning, or transition to larger, fewer trees in more fertile sites has been observed before and is known as the Sukatchew effect (Harper, 1977; Henry et al., 1999). Changes in stand density thus have the potential to diminish the impact of $\mathrm{N}$-stimulated growth on overall C storage in aboveground biomass.

With respect to the composition of trees, of the 21 tree species found in the Fernow LTSP plots, pin cherry $(P$. pensylvanica $)$ was clearly dominant. This species was the most abundant, had the largest individual trees, and accounted for at least $40 \%$ of the total relative importance value (RIV) on each treatment plot. Surprisingly, however, despite the predominance of $P$. pensylvanica, the overall treatment effects on biomass per tree and stand density were the result of changes in several species rather than changes in only the dominant species. For example, the overall increase in biomass per tree in plots 
receiving only ammonium sulfate was not detected for P. pensylvanica alone or for the four most dominant species (Fig. 2.6).

The response of tree species other than P. pensylvanica may be especially important because $P$. pensylvanica is a short lived (25-30 years), early successional species in temperate deciduous forests of the Eastern US (Marks and Borman, 1972; Marks, 1974). Thus, the response of later successional species in these regenerating stands may significantly influence the long-term effects of $\mathrm{N}$ additions on overall $\mathrm{C}$ storage as these forests age. Indeed, no P. pensylvanica was found in the mature forest that was cut to initiate the LTSP experiment (Adams et al., 2004). The effect of $\mathrm{N}$ addition on the 3 most dominant, longer-lived species (Betula lenta, Liriodendron tulipifera, and Prunus serotina) was significantly different than that for P. pensylvanica. Liriodendron tulipifera appears to show a negative response to soil acidification that may be reversible through the addition of lime. Although lime additions have not been made in the nearby watershed fertilization experiment (WS 3), it has been documented that individual $L$. tulipifera trees grew more slowly than those in a reference watershed (WS 7) after 7 years of ammonium sulfate additions (DeWalle et al., 2006; May et al., 2005). In contrast, the biomass of $B$. lenta in the Fernow LTSP plots was negatively affected by N additions with, or without, lime additions suggesting that the direct effect of $\mathrm{N}$ was more important for this species than any indirect effect due to $\mathrm{N}$-induced soil acidification.

With respect to species diversity at the scale of the total area sampled in each plot $(0.486$ ha), this is the only experimental study I am aware of that has documented a $\mathrm{N}$-induced 
reduction in the richness of trees species (Fig. 2.5). While not dramatic (a reduction of $\sim$ 2 species in the NS plots), this result supported other observations from the Fernow Experimental Forest that revealed: (1) temporal reductions in tree species diversity in areas with a high, but not with a low, site index (Schuler, 2004); and (2) an inverse relationship in two reference watersheds between tree species richness in small plots (10$\mathrm{m}$ radius) and a measured index of soil $\mathrm{N}$ availability $(\mathrm{r}=-0.63$; Peterjohn, unpublished $)$. It was also interesting to note that no treatment effect was found for Shannon's Index of diversity, and plots receiving both ammonium sulfate and lime showed no detectable change in species richness. Importantly, the apparent effect of lime additions suggested that reductions in the number of tree species was an indirect effect of $\mathrm{N}$ additions on soil acidification or other factors that could be ameliorated through the addition of lime, such as the replacement of base cations and/or a reduction in the levels of soluble $\mathrm{Al}^{3+}$.

In summary, 13 years of ammonium sulfate additions to a regenerating deciduous forest stimulated its ability to store $\mathrm{C}$, even in a region with historically high levels of atmospheric $\mathrm{N}$ deposition. This response was driven primarily by increased $\mathrm{C}$ storage in aboveground biomass and to a lesser extent by increased $\mathrm{C}$ stored in the forest floor. Despite the dominance of a single tree species, the overall response was a complex mixture of species-specific changes in the growth of individuals that may have been tempered by stand density. Unlike other studies, indirect effects of $\mathrm{N}$ additions that could be mitigated by lime additions were found to influence $\mathrm{C}$ accumulation on the forest floor as well as the number of tree species, suggesting that the interpretation of results from fertilization experiments need to consider the indirect effects of soil acidification that 
may co-occur with the direct effects of $\mathrm{N}$ additions. Finally, given the differential responses observed for longer-lived tree species versus the positive response for shortlived species, it appears that the long-term effects of $\mathrm{N}$ deposition on $\mathrm{C}$ storage in temperate deciduous forests may be different than the short-term effects and may even be negative. 


\subsection{Tables and Figures.}

Table 2.1. A list of all species found, the abbreviation used to represent each of them, and the total relative importance value for each. The relative importance value for each species was calculated regardless of treatment.

\begin{tabular}{ccc}
\hline Species & Abbreviation & Overall RIV \\
\hline \hline Prunus pensylvanica & PRPE & 0.519 \\
Liriodendron tulipifera & LITU & 0.128 \\
Betula lenta & BELE & 0.124 \\
Prunus serotina & PRSE & 0.075 \\
Acer rubrum & ACRU & 0.042 \\
Acer pensylvanicum & ACPE & 0.023 \\
Quercus rubra & QURU & 0.016 \\
Aralia spinosa & ARSP & 0.016 \\
Robinia pseudoacacia & ROPS & 0.014 \\
Magnolia acuminata & MAAC & 0.010 \\
Magnolia fraseri & MAFR & 0.009 \\
Acer saccharum & ACSA & 0.005 \\
Carpinus caroliniana & CACA & 0.004 \\
Ostrya virginiana & OSVI & 0.004 \\
Tilia americana & TIAM & 0.003 \\
Sassafrass albidum & SAAL & 0.002 \\
Fraxinus americana & FRAM & 0.002 \\
Quercus prinus & QUPR & 0.001 \\
Betula alleghaniensis & BEAL & 0.001 \\
Oxydendrum arboreum & OXAR & 0.001 \\
Ilex montana & ILMO & $<0.001$ \\
\hline
\end{tabular}


Figure 2.1. The LTSP plots at Fernow experimental forest. The x's in the expanded views represent the permanent stakes, and the expanded views illustrate how plots were divided into 12 or 192 squares for sampling purposes (Adams et al., 2004).

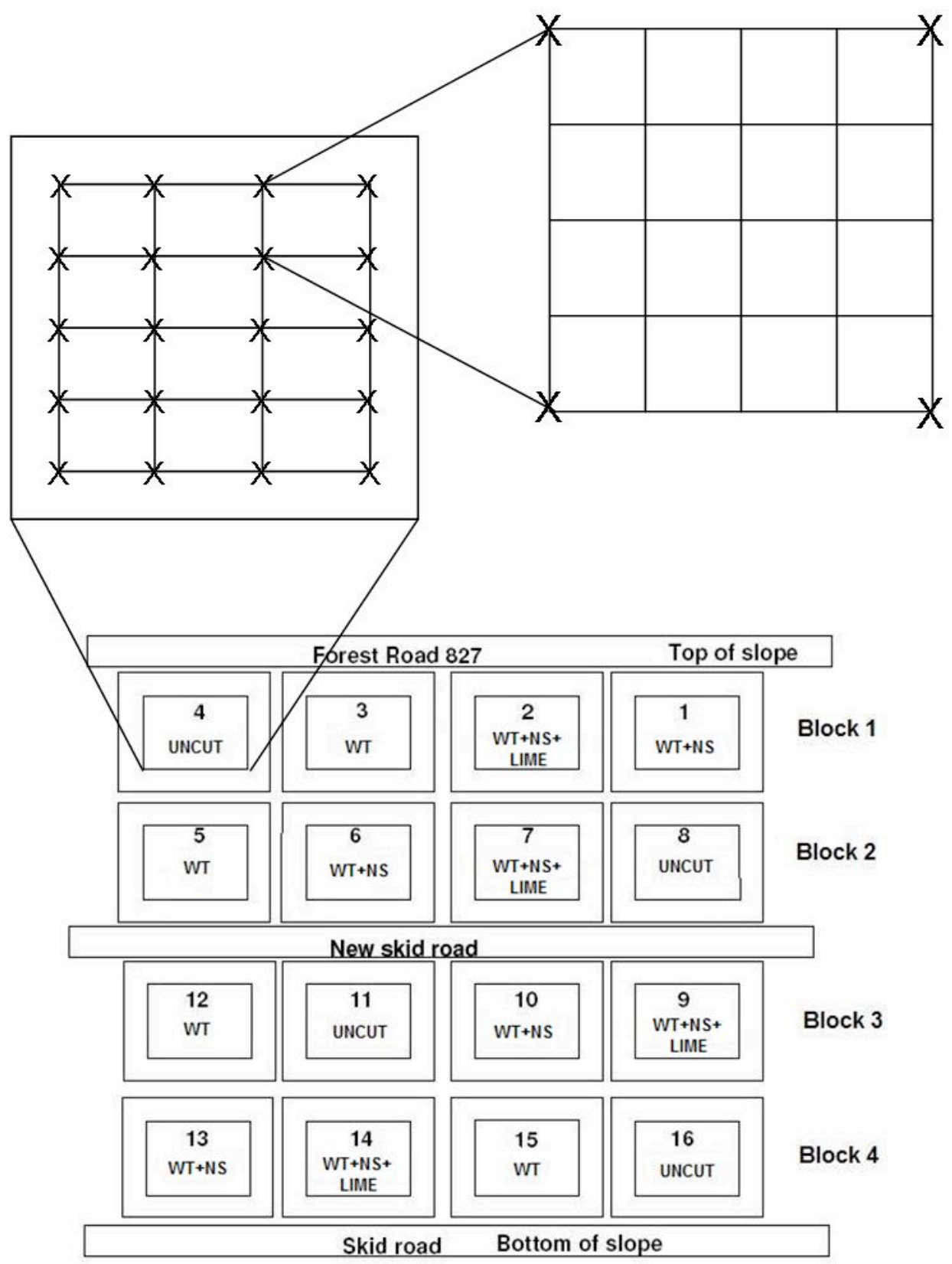


Figure 2.2. Average total measured $\mathrm{C}$ pool after 13 years of treatment. Total measured $\mathrm{C}$ pool includes aboveground tree biomass, the forest floor, fine roots in the top $10 \mathrm{~cm}$, and the top $5 \mathrm{~cm}$ soil. Error bars are one standard error, and bars with different letters had significantly different means at $\mathrm{p}<0.05$ in post hoc analysis.

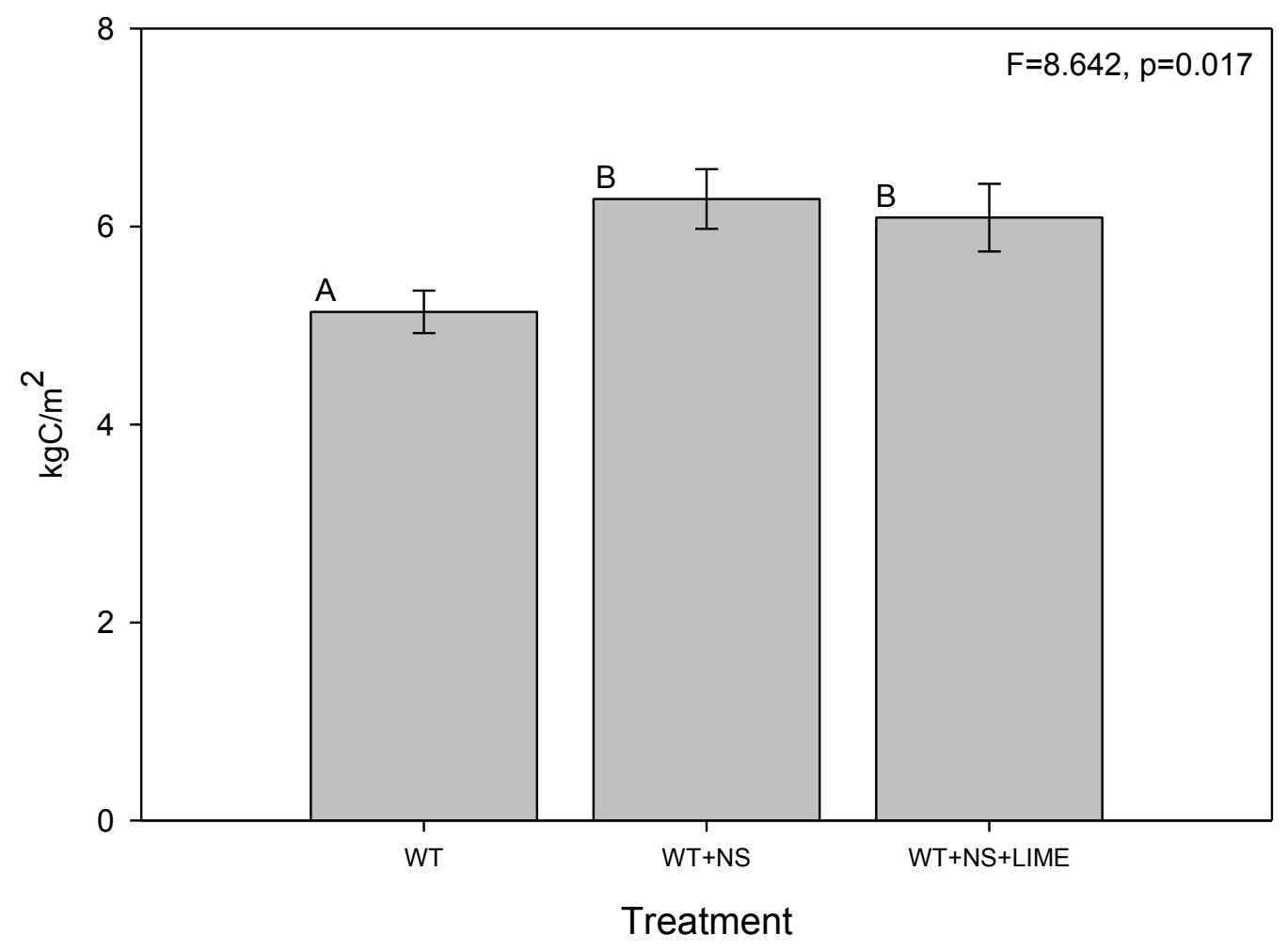


Figure 2.3. Average $\mathrm{C}$ pools after 13 years of treatment. Error bars are one standard error, values with different capital letters are significantly different $(p<0.05)$, and those with different lowercase letters show a trend towards differences $(\mathrm{p}<0.1)$ in post hoc analyses.

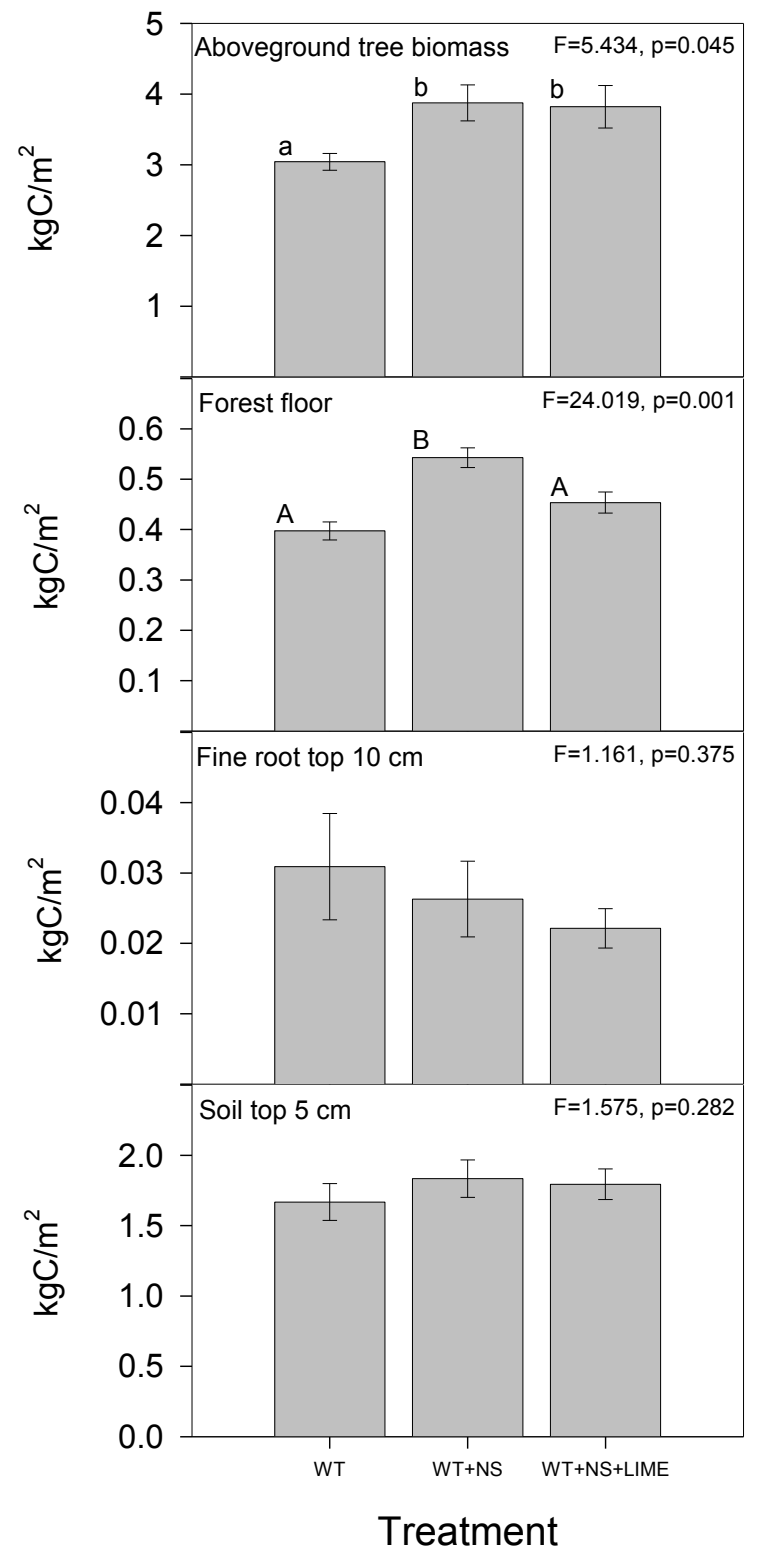


Figure 2.4. Average biomass per tree and density of trees per area after 13 years of treatment, regardless of species. Error bars are one standard error, and bars with different letters were found to have different means in post hoc analysis.

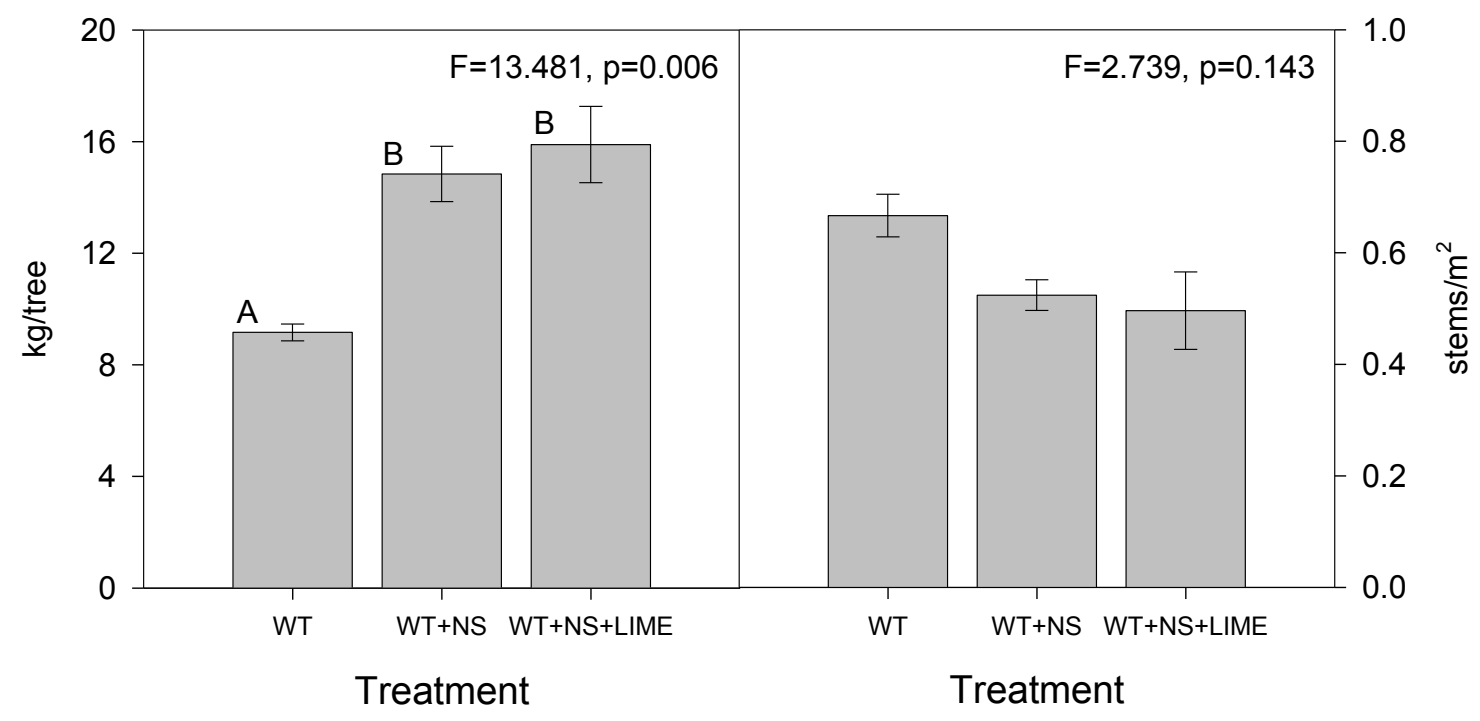


Figure 2.5. Average species richness of trees in total area sampled per plot after 13 years of treatment. Error bars are one standard error, and bars with different letters had significantly different means in post hoc analysis.

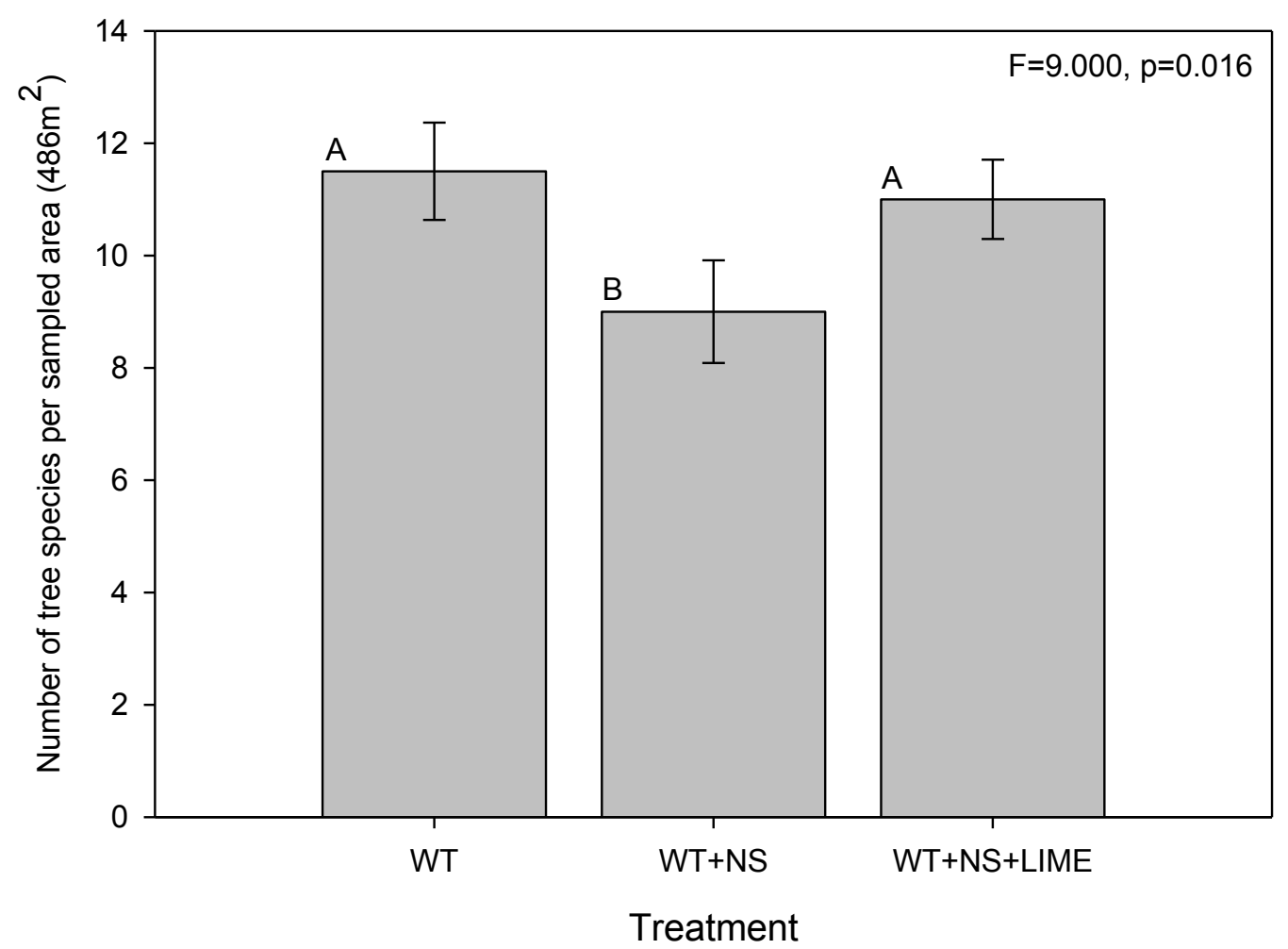


Figure 2.6. Average biomass per tree after 13 years of treatment by species. Each of the species which individually make up more than 5\% of the total RIV are considered. Error bars are one standard error. Data graphed are untransformed data, but statistics were done on $\log$ transformed data. (PRPE = Prunus pensylvanica, LITU = Liriodendron tulipifera, $\mathrm{BELE}=$ Betula lenta, PRSE $=$ Prunus serotina $)$

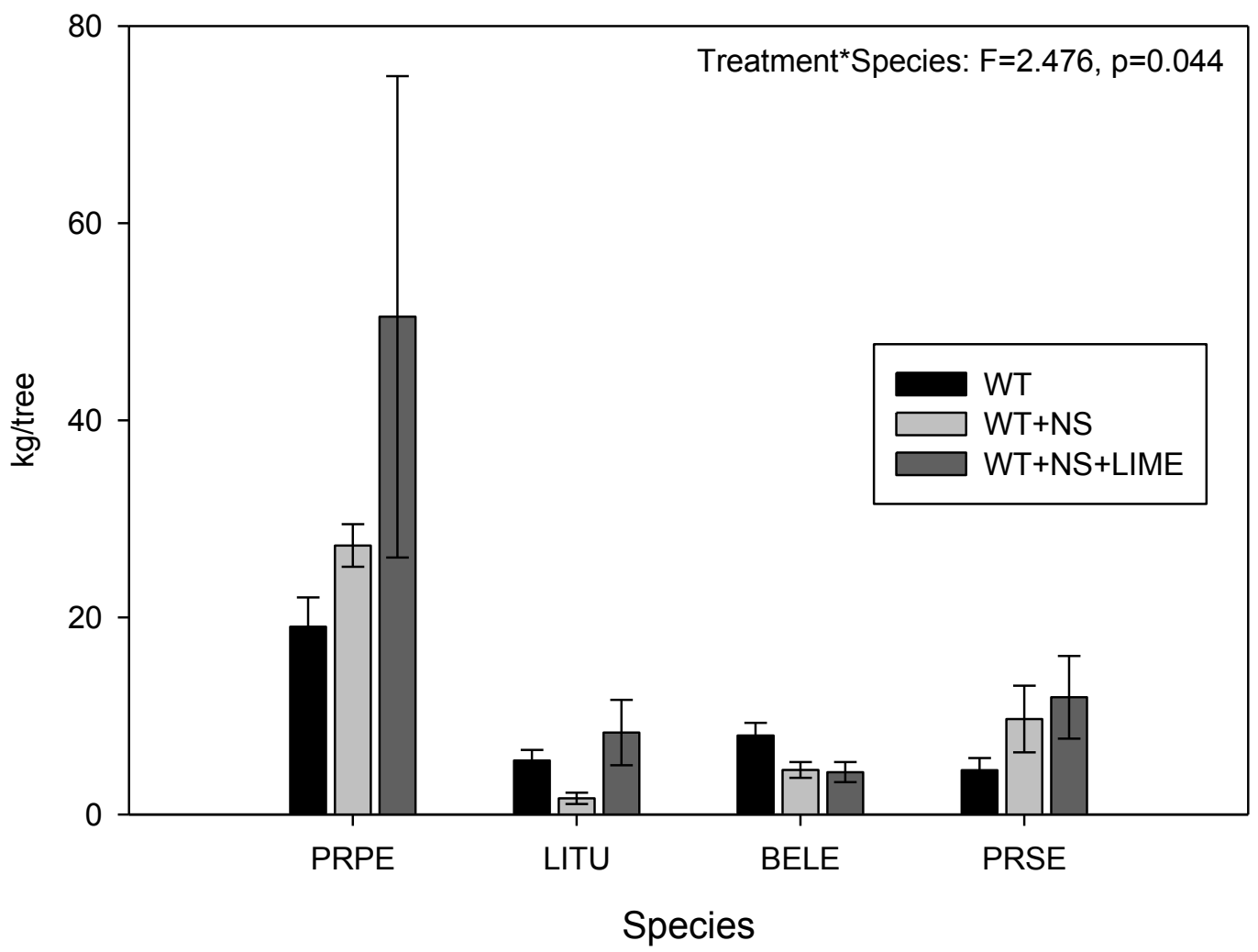




\subsection{Literature Cited.}

Aber, J. D. and C. T. Driscoll. 1997. Effects of land use, climate variation, and N deposition on $\mathrm{N}$ cycling and $\mathrm{C}$ storage in northern hardwood forests. Global Biogeochemical Cycles 11: 639-648.

Aber, J. D., W. McDowell, K. Nadelhoffer, A. Magill, G. Berntson, M. Kamakea, S. McNulty, W. Currie, L. Rustad, and I. Fernandez. 1998. Nitrogen saturation in temperate forest ecosystems. BioScience 48: 921-934.

Adams, M. B. 2003. Ecological issues related to $\mathrm{N}$ deposition to natural ecosystems: research needs. Environment International 29: 189-199.

Adams, M. B. and T. R. Angradi. 1996. Decomposition and nutrient dynamics of hardwood leaf litter in the Fernow whole-watershed acidification experiment. Forest Ecology and Management 83: 61-69.

Adams, M. B., J. A. Burger, A. B. Jenkins, and L. Zelazny. 2000. Impact of harvesting and atmospheric pollution on nutrient depletion of eastern US hardwood forests. Forest Ecology and Management 138: 301-319.

Adams, M. B., J. Burger, L. Zelazny, and J. Baumgras. 2004. Description of the Fork Mountain long-term soil productivity study: Site characterization. USDA Forest Service, Newtown Square, PA.

Ainsworth, E. A. and S. P. Long. 2005. Tansley review. What have we learned from 15 years of free-air $\mathrm{CO}_{2}$ enrichment (FACE)? A meta-analytic review of the responses of phototsynthesis, canopy properties and plant production to rising $\mathrm{CO}_{2}$. New Phytologist 165: 351-372.

Auchmoody, L. R., and H. C. Smith. 1977. Response of yellow-poplar and red oak to fertilization in West Virginia. Soil Science Society of America Journal 41: 803807.

Boggs, J. L., S. G. McNulty, M. J. Gavazzi, and J. Moore Myers. 2005. Tree growth, foliar chemistry, and nitrogen cycling across a nitrogen deposition gradient in southern Appalachian deciduous forests. Canadian Journal of Forest Research 35: 1901-1913.

Brenneman, B.B., Frederick, D.J., Gardner, W.E., Schoenhofen, L.H., and P. L. Marsh. 1978. Biomass of species and stands of West Virginia hardwoods. In: Pope, P.E., ed. Proceedings of Central Hardwood Forest Conference II, Purdue University, West LaFeyette, IN: 159-178. 
Burns, D. A., J. A. Lynch, B. J. Cosby, M. E. Fenn, and J.S. Baron. 2011. National Acid Precipitation Assessment Program report to Congress 2011: An integrated assessment. US EPA Clean Air Markets Div., National Science and Technology Council, Washington, DC, $114 \mathrm{p}$.

Ciais, P., P. P. Tans, M. Trolier, J. W. C. White, and R. J. Francey. 1995. A large Northern Hemisphere terrestrial $\mathrm{CO}_{2}$ sink indicated by the ${ }^{13} \mathrm{C} /{ }^{12} \mathrm{C}$ ratio of atmospheric $\mathrm{CO}_{2}$. Science 269: 1098-1102.

de Vries, W., S. Solberg, M. Dobbertin, J. Sterba, D. Laubhahn, G. J. Reinds, G. Nabuurs, P. Gundersen, and M. A. Sutton. 2008. Ecologically implausible carbon response? Nature 451: E1-E3.

DeWalle, D. R., J. L. Hom, and M. B. Adams. 2006. Introduction to the Fernow watershed acidification study. In: M. B. Adams et al. (eds.), The Fernow watershed acidification study. Springer, The Netherlands: 1-16.

DeForest, J. L., D. R. Zak, K. S. Pregitzer, and A. J. Burton. 2005. Atmospheric nitrate deposition and enhanced dissolved organic carbon leaching: Test of a potential mechanism. Soil Science Society of America Journal 69: 1233-1237.

Dentener, F., D. Stevenson, K. Ellingsen, T. Van Noije, M. Schultz, M. Amann, C. Atherton, N. Bell, D. Bergmann, I. Bey, L. Bouwman, T. Buler, J. Cofala, B. Collins, J. Drevet, R. Doherty, B. Eickhout, H. Eskes, A. Fiore, M Gauss, D. Hauglustaine, L. Horowitz, I S. A. Isaksen, B. Josse, M. Lawrence, M. Krol, J. F. Lamarque, V. Montanaro, J. F. Muller, V. H. Peuch, G. Pitari, J. Pyle, S. Rast, J. Rodriguez, M. Sanderson, N. H. Savage, D. Shindell, S. Strahan, S. Szopa, K. Sudo, R. Van Dingenen, O. Wild, and G. Zeng. 2006. The global atmospheric environment for the next generation. Environmental Science and Technology 40: 3586-3594.

Edwards, I. P., D. R. Zak, H. Kellner, S. D. Eisenlord, and K. S. Pregitzer. 2011. Simulated atmospheric $\mathrm{N}$ deposition alters fungal community composition and suppresses ligninolytic gene expression in a northern hardwood forest. PLoS ONE 6: 1-10.

Elias, P. E., J. A. Burger, and M. B. Adams. 2009. Acid deposition effects on forest composition and growth on the Monongahela National Forest, West Virginia. Forest Ecology and Management 258: 2175-2182.

Elser, J. J., M. E. S. Bracken, E. E. Cleland, D. S. Gruner, W. S. Harpole, H. Hillebrand, J. T. Ngai, E. W. Seabloom, J. B. Shurin, and J. E. Smith. 2007. Global analysis of nitrogen and phosphorous limitation of primary producers in freshwater, marine and terrestrial ecosystems. Ecology Letters 10: 1135-1142. 
Federer, C. A., J. W. Hornbeck, L. M. Tritton, C. W. Martin, and R. S. Pierce. 1989. Long-term depletion of calcium and other nutrients in eastern US forests. Environmental Management 13: 593-601.

Fenn, M. E., M. A. Poth, J. D. Aber, J. S. Baron, B. T. Bormann, D. W. Johnson, A. D. Lemly, S. G. McNulty, D. F. Ryan, and R. Stottlemyer. 1998. Nitrogen excess in North American ecosystems: predisposing factors, ecosystem responses, and management strategies. Ecological Applications 8: 706-733.

Fleischer, K., K. T. Rebel, M. K. van der Molen, J. W. Erisman, M. J. Wassen, E. E. van Loon, L. Montagnani, C. M. Gough, M. Herbst, I. A. Janssens, D. Gianelle, and A. J. Dolman. 2013. The contribution of nitrogen deposition to the photosynthetic capacity of forests. Global Biogeochemical Cycles 27: 1-13.

Fog, K. 1988. The effect of added nitrogen on the rate of decomposition of organic matter. Biological Reviews 63: 433-462.

Galloway, J. N., G. E. Likens, and E. S. Edgerton. 1976. Acid precipitation in the northeastern United States: $\mathrm{pH}$ and acidity. Science 194: 722-724.

Galloway, J. N., Z. Dianwu, X. Jiling, and G. E. Likens. 1987. Acid rain: China, United States, and a remote area. Science 236: 1559-1562.

Galloway, J. N., F. J. Dentener, D. G. Capone, E. W. Boyer, R. W Howarth, S. P. Seitzinger, G. P. Asner, C. C. Cleveland, P. A. Green, E. A. Holland, D. M. Karl, A. F. Michaels, J. H. Porter, A. R. Townsend, and C. J. Vorosmarty. 2004. Nitrogen cycles: past, present, and future. Biogeochemistry 70: 153-226.

Goodale, C. L., M. J. Apps, R. A. Birdsey, C. B. Field, L. S. Heath, R. A. Houghton, J. C. Jenkins, G. H. Kohlmaier, W. Kurtz, S. Liu, G. Nabuurs, S. Nilsson, and A. Z. Shvidenko. 2002. Forest carbon sinks in the northern hemisphere. Ecological Applications 12: 891-899.

Harper, J.L. 1977. Population biology of plants. Academic Press, London.

Henry, M., H. Stevens, and W. P. Carson. 1999. The significance of assemblage-level thinning for species richness. Journal of Ecology 87: 490-502.

Hobbie, S. 2008. Nitrogen effects on decomposition: a five-year experiment in eight temperate sites. Ecology 89: 2633-2644.

Houghton, R. A., E. A. Davidson, and G. M. Woodwell. 1998. Missing sinks, feedbacks, and understanding the role of terrestrial ecosystems in the global carbon balance. Global Biogeochemical Cycles 12: 25-34.

JMP, Version 10. SAS Institute Inc., Cary, NC, 1989-2007. 
Johnson, B. A., K. B. Piatek, M. B. Adams, and J. R. Brooks. 2010. Does nitrogen and sulfur deposition affect forest productivity? In: Rentch, J. S.; Schuler, Thomas M., eds. Proceedings from the conference on the ecology and management of highelevation forests in the Central and Southern Appalachian Mountains. 2009 May 14-15; Slatyfork, WV. Gen. Tech. Rep. NRS-P-64. Newtown Square, PA: U.S. Department of Agriculture, Forest Service, Northern Research Station: 85-93.

Kim, S. W., A. Heckel, S. A. McKeen, G. J. Frost, E. Y. Hsie, M. K. Trainer, A. Richter, J. P. Burrows, S. E. Peckham, and G. A. Grell. 2006. Satellite-observed U.S. power plant NOx emission reductions and their impact on air quality. Geophysical Research Letters 33: 1-5.

Knorr, M., S. D. Frey, and P. S. Curtis. 2005. Nitrogen addition and litter decomposition: A meta-analysis. Ecology 86: 3252-3257.

LeBauer, D. S. and K. K. Treseder. 2008. Nitrogen limitation of net primary productivity in terrestrial ecosystems is globally distributed. Ecology 89: 371379.

Le Quere, C., R. J. Andres, T. Boden, T. Conway, R. A. Houghton, J. I House, G. Marland, G. P. Peters, G. van der Werf, A. Ahlstrom, R. M. Andrew, L. Bopp, J. G. Canadell, P. Ciais, S. C. Doney, C. Enright, P. Friedlingstein, C. Huntingford, A. K. Jain, C. Jourdain, E. Kato, R. F. Keeling, K. Klein Goldewijk, S. Levis, P. Levy, M. Lomas, B. Poulter, M. R. Raupach, J. Schwinger, S. Sitch, B. D. Stocker, N. Viovy, S. Zaehle, and N. Zeng. 2012. The global carbon budget 1959-2011. Earth System Science Data Discussions 5: 1107-1157.

Likens, G. E., C. T. Driscoll, and D. C. Buso. 1996. Long-term effects of acid rain: Response and recovery of a forest ecosystem. Science 272: 244-246.

Liu, L. and T. L. Greaver. 2009. A review of nitrogen enrichment effects on three biogenic GHGs: the CO2 sink may be largely offset by stimulated $\mathrm{N} 2 \mathrm{O}$ and $\mathrm{CH} 4$ emission. Ecology Letters 12: 1103-1117.

Magill, A. H., M. R. Downs, K. J. Nadelhoffer, R. A. Hallett, and J. D. Aber. 1996. Forest ecosystem response to four years of chronic nitrate and sulfate additions at Bear Brooks Watershed, Maine, USA. Forest Ecology and Management 84: 2937.

Magill, A. H. and J. D. Aber. 1998. Long-term effects of experimental nitrogen additions on foliar litter decay and humus formation in forest ecosystems. Plant and Soil 203: 301-311. 
Magill, A. H., J. D. Aber, W. S. Currie, K. J. Nadelhoffer, M. E. Martin, W. H. McDowell, J. M. Melillo, and P. Steudlar. 2004. Ecosystem response to 15 years of chronic nitrogen additions at the Harvard Forest LTER, Massachusetts, USA. Forest Ecology and Management 196: 7-28.

Magnani, F., M. Mencuccini, M. Borghetti, P. Berbigier, F. Berninger, S. Delzon, A. Grelle, P. Hari, P. G. Jarvis, P. Kolari, A. S. Kowalski, H. Lankreijer, B. E. Law, A. Lindroth, D. Loustau, G. Manca, J. B. Moncrieff, M. Rayment, B. Tedeschi, R. Valentini, and J. Grace. 2007. The human footprint in the carbon cycle of temperate and boreal forests. Nature 447: 848-852.

Marks, P. L. and F. H. Borman. 1972. Revegetation following forest cutting: Mechanisms for return to steady-state nutrient cycling. Science 176: 914-915.

Marks, P. L. 1974. The role of pin cherry (Prunus pensylvanica L.) in the maintenance of stability in northern hardwood ecosystems. Ecological Monographs 44: 73-88.

May, J. D., S. B. Burdette, F. S. Gilliam, and M. B. Adams. 2005. Interspecific divergence in foliar nutrient dynamics and stem growth in a temperate forest in response to chronic nitrogen inputs. Canadian Journal of Forest Research 35: 1023-1030.

McNulty, S.G., J. Boggs, J.D. Aber, L. Rustad, and A. Magill. 2005. Red spruce ecosystem level changes following 14 years of chronic $\mathrm{N}$ fertilization. Forest Ecology and Management 219:279-291.

Mitchell, H. L. and R. F. Chandler, Jr. 1939. The nitrogen nutrition and growth of certain deciduous trees of Northeastern United States. The Black Rock Forest Bulletin 11: 1-94.

Nadelhoffer, K. J., J. D. Aber, and J. M. Melillo. 1985. Fine roots, net primary production, and soil nitrogen availability: A new hypothesis. Ecology 66: 13771390.

Nadelhoffer, K. J., B. A. Emmett, P. Gunderson, O. J. Kjonaas, C. J. Koopmans, P. Schleppi, A. Tietema, and R. F. Wright. 1999. Nitrogen deposition makes a minor contribution to carbon sequestration in temperate forests. Nature 398: $145-148$.

Nadelhoffer, K. J. 2000. Research review: The potential effects of nitrogen deposition on fine-root production in forest ecosystems. New Phytologist 147: 131-139.

National Atmospheric Deposition Program/National Trends Network. 2000. 1996 annual and seasonal data summary for Site WV18. nadp.sws.uiuc.edu/ads/1996/wv18.pdf. 
National Atmospheric Deposition Program/National Trends Network. 2009. 2008 annual and seasonal data summary for site WV18.

nadp.sws.uiuc.edu/ads/2008/wv18.pdf.

Nelson, D.W. and L.E. Sommers. 1982. Total carbon, organic carbon, and organic matter. Pages 539-579 in A.L. Page, editor. Methods of soil analysis. Part 2. American Society of Agronomy and Soil Science Society of America, Madison, Wisconsin, USA.

Ollinger, S. V., A. D. Richardson, M. E. Martin, D. Y. Hollinger, S. E. Frolking, P. B. Reich, L. C. Plourde, G. G. Katul, J. W. Munger, R. Oren, M. L. Smith, K. T. Paw U, P. B. Bolstad, B. D. Cook, M. C. Day, T. A. Martin, R. K. Monson, and H. P. Schmidi. 2008. Canopy nitrogen, carbon assimilation, and albedo in temperate and boreal forests: Functional relations and potential climate feedbacks. Proceedings of the National Academy of Scientists 105: 19335-19340.

Pan, Y., R. A. Birdsey, J. Fang, R. Houghton, P. E. Kauppi, W. A. Kurz, O. L. Phillips, A. Shvidenko, S. L. Lewis, J. G. Canadell, P. Ciais, R. B. Jackson, S. Pacala, A. D. McGuire, S. Piao, A. Rautiainen, S. Sitch, and D. Hayes. 2011. A large and persistent carbon sink in the world's forests. Science 333: 988-993.

Pregitzer, K. S., A. J. Burton, D. R. Zak, and A. F. Talhelm. 2008. Simulated chronic nitrogen deposition increases carbon storage in northern temperate forests. Global Change Biology 14: 142-153.

Ramirez, K. S., J. M. Craine, and N. Fierer. 2012. Consistent effects of nitrogen amendments on soil microbial communities and processes across biomes. Global Change Biology 18: 1918-1927.

Reay, D. S., F. Dentener, P. Smith, J. Grace, and R. A. Feely. 2008. Global nitrogen deposition and carbon sinks. Nature Geosciences 1: 430-437.

Reich, P. B., D. F. Grigal, J. D. Aber, and S. T. Gower. 1997. Nitrogen mineralization and productivity in 50 hardwood and conifer stands on diverse soils. Ecology 78: 335-347.

Schimel, D. S. 1995. Terrestrial ecosystems and the carbon cycle. Global Change Biology 1: 77-91.

Shuxia, J., Z. Wang, X. Li, Y. Sun, X. Zhang, and A. Liang. 2010. N fertilization affects on soil respiration, microbial biomass and root respiration in Larix Gmelinii and Fraxinus mandshurica plantations in China. Plant and Soil 333: 325-336. 
Sutton, M. A., D. Simpson, P. E. Levy, R. I. Smith, S. Reis, M. VanOijen, and W. DeVries. 2008. Uncertainties in the relationship between atmospheric nitrogen deposition and forest carbon sequestration. Global Change Biology 14: 20572063.

Templer, P. H., M. C. Mack, F. S. Chapin, III, L. M. Christenson, J. E. Compton, H. D. Crook, W. S. Currie, C. J. Curtis, D. B. Dail, C. M. D’Antonio, B. A. Emmett, H. E. Epstein, C. L. Goodale, P. Gundersen, S. E. Hobbie, K. Holland, D. U. Hooper, B. A. Hungate, S. Lamontagne, K. J. Knadelhoffer, C. W. Osenberg, S. S. Perakis, P. Schleppi, J. Schimel, I. K. Schmidt, M. Sommerkorn, J. Spoelstra, A. Tietema, W. W. Wessel, and D. R. Zak. 2012. Sinks for nitrogen inputs in terrestrial ecosystems: a meta-analysis of ${ }^{15} \mathrm{~N}$ tracer field studies. Ecology 93: 1816-1829.

Thomas, R. Q., C. D. Canham, K. C. Weathers, and C. L. Goodale. 2010. Increased tree carbon storage in response to nitrogen deposition in the US. Nature Geoscience 3: $13-17$.

Tilman, D. 1993. Species richness of experimental productivity gradients: How important is colonization limitation? Ecology 74: 2179-2191.

Vitousek, P. M. and W. A. Reiners. 1975. Ecosystem succession and nutrient retention: A hypothesis. BioScience 25: 376-381.

Vitousek, P. M., T. Fahey, D. W. Johnson, and M. J. Swift. 1988. Element interactions in forest ecosystems: Succession, allometry and input-output budgets. Biogeochemistry 5: 7-34.

Vitousek, P. M., J. D. Aber, R. W. Howarth, G. E. Likens, P. A. Matson, D. W. Schindler, W. H. Schlesinger, and D. G. Tilman. 1997. Human alteration of the global nitrogen cycle: sources and consequences. Ecological Applications 7: 737-750.

Whittinghill, K. A., W. S. Currie, D. R. Zak, A. J. Burton, and K. S. Pregitzer. 2012. Anthropogenic $\mathrm{N}$ deposition increases soil $\mathrm{C}$ storage by decreasing the extent of litter decay: Analysis of field observations with an ecosystem model.

Ecosystems 15: 450-461.

Zak, D. R., W. E. Holmes, A. J. Burton, K. S. Pregitzer, and A. F. Talhelm. 2008. Simulated atmospheric NO3- deposition increases soil organic matter by slowing decomposition. Ecological Applications 18: 2016-2027. 
Chapter 3. Symptoms of soil acidification in young forest stands following enhanced nitrogen deposition: Evidence of changes in calcium, magnesium, and aluminum levels in soil and foliage. 


\subsection{Abstract.}

Although nitrogen $(\mathrm{N})$ in acid deposition may initially stimulate productivity and carbon (C) storage in forest ecosystems, the magnitude and longevity of this stimulation may be diminished by soil acidification and associated soil changes. I used the Fernow Experimental Forest Long Term Soil Productivity (LTSP) experiment near Parsons, WV to study the impacts of accelerated $\mathrm{N}$ deposition on soil and foliar chemistry in an aggrading temperate deciduous forest growing on soil derived from base-poor parent material. This study examined exchangeable and resin-available nutrient levels in soil and nutrient concentrations in foliar samples to determine if negative effects of acidification due to experimental ammonium sulfate additions could be detected prior to any negative effects on the cumulative growth of the trees.

I found that after years of annual ammonium sulfate additions, soil and foliar chemistry in an aggrading temperate deciduous forest showed signs of the onset of soil acidification and calcium $(\mathrm{Ca})$ and magnesium $(\mathrm{Mg})$ depletion. Additionally, liming may mitigate some of the negative impacts of acidification for experimental or management purposes. More specifically, I found patterns of decreases in soil and foliar $\mathrm{Ca}$ and $\mathrm{Mg}$ levels and increases in soil and foliar aluminum (Al) levels in plots receiving experimental $\mathrm{N}$ additions when compared with those of plots not receiving $\mathrm{N}$ additions or plots receiving $\mathrm{N}$ additions along with dolomitic limestone additions.

These results suggest that the initial increase in tree growth observed in these stands following $\mathrm{N}$ additions could be short-lived without concurrent mitigation efforts. Thus, it appears that stimulation of tree growth and $\mathrm{C}$ storage due to acidic deposition may be short-term due to changes in soil chemistry. 


\subsection{Introduction.}

Fossil-fuel burning has enhanced acidic deposition in temperate deciduous forests that are downwind from significant sources of sulfur dioxide $\left(\mathrm{SO}_{2}\right)$ and oxidized nitrogen $\left(\mathrm{NO}_{\mathrm{x}}\right)$ emissions. Since nitric acid is an important component of acid rain, acidic deposition has increased the amount of available nitrogen $(\mathrm{N})$ in large regions of these temperate forests (Driscoll et al., 2001). N availability typically limits, or co-limits, productivity in terrestrial ecosystems (Vitousek and Howarth 1991; Elser et al. 2007), so the increased availability of $\mathrm{N}$ is likely to stimulate tree growth and strengthen their contribution to the terrestrial carbon (C) sink (Aber et al., 1989). Indeed, this conclusion is supported by experimental and observational studies in which enhanced inputs of available $\mathrm{N}$ have significantly increased tree growth and C storage (Thomas et al., 2010; Magill et al., 2004; Nadelhoffer et al., 1985; Pregitzer et al., 2008).

Results from some $\mathrm{N}$ addition experiments, however, suggest that a $\mathrm{N}$-induced stimulation of tree growth and C storage may be short-lived due detrimental effects associated with N saturation and soil acidification (DeWalle et al., 2006; Magill et al., 1996; McNulty et al., 2005). Nitrogen saturation, defined as $\mathrm{N}$ availability in excess of biotic demand, can result from chronic $\mathrm{N}$ inputs that accumulate in a system and ultimately lead to leaching of nitrate $\left(\mathrm{NO}_{3}{ }^{-}\right)$from forest soils. This $\mathrm{NO}_{3}{ }^{-}$leaching can result in calcium $\left(\mathrm{Ca}^{2+}\right)$ and magnesium $\left(\mathrm{Mg}^{2+}\right)$ losses as well and, eventually, soil acidification and depletion of $\mathrm{Ca}$ and $\mathrm{Mg}$ available for plant uptake along with increases

in toxic aluminum $\left(\mathrm{Al}^{3+}\right)$ availability. Soil acidification, $\mathrm{Ca}$ and $\mathrm{Mg}$ depletion, and $\mathrm{Al}$ 
toxicity all have the potential to reduce tree growth and thereby diminish the magnitude and duration of any initial $\mathrm{N}$-induced stimulation of $\mathrm{C}$ sequestration due to enhanced forest productivity (Aber et al., 1998; Fernandez et al., 2003).

The timing of the onset of $\mathrm{N}$ saturation and soil acidification in temperate deciduous forests is thought to depend on the age of the forest and the type of soil on which it is growing. Young, aggrading forests are thought to be more $\mathrm{N}$ limited than mature forests and, thus, more likely to increase in growth and less likely to be N saturated (Fenn et al., 1998). Soils derived from base-poor parent materials, such as sandstone, are more susceptible to the negative impacts associated with enhanced leaching losses of nutrient cations (especially $\mathrm{Ca}$ and $\mathrm{Mg}$ ) than are soils derived from more limestone-rich parent materials (Adams et al., 2000). Young, aggrading forests growing on soil derived from base-poor parent material are thus particularly susceptible. These young forests are likely to experience a growth increase in response to elevated $\mathrm{N}$ inputs from acidic deposition, and may potentially contribute to an enhanced terrestrial $\mathrm{C}$ sink. However, once $\mathrm{N}$ saturation is reached in these forests, their soils are vulnerable to the long-lasting negative effects of $\mathrm{NO}_{3}{ }^{-}$leaching such as acidification, $\mathrm{Ca}$ and $\mathrm{Mg}$ depletion, and $\mathrm{Al}$ mobilization, which are likely to reduce the future capacity of these forests to sequester C.

The Fernow Experimental Forest Long Term Soil Productivity (LTSP) study near Parsons, WV (Adams et al., 2004) provides an opportunity to study the effects of enhanced $\mathrm{N}$ deposition on young, aggrading temperate deciduous forests growing on soil derived from base-poor parent material. Previous research in the Fernow LTSP plots 
(Fowler et al., unpublished) has found that 13 years of experimental ammonium sulfate additions led to increased cumulative tree growth and $\mathrm{C}$ storage. However, there were differential growth responses for different tree species, and another study at Fernow Experimental Forest, conducted at the watershed level, found that long-term ammonium sulfate additions to a small watershed led to short-lived, species-specific increases in tree growth that were followed by sustained reductions in growth rates (DeWalle et al., 2006). If the younger trees growing on the Fernow LTSP plots were to respond in a similar fashion (short-lived growth stimulation followed by a reduced growth rates), then it is likely that changes in soil and tissue chemistry indicative of acidification effects will precede or co-occur with the shift from enhanced to reduced growth rates of the vegetation.

This study examined nutrient levels in soil and foliage after at least 10 years of ammonium sulfate additions to the Fernow LTSP study in order to determine if negative effects of acidification could be detected in soil and foliage, even before cumulative growth was diminished in a detectable manner. Specifically, I hypothesized that longterm experimental ammonium sulfate addition to a young aggrading temperate deciduous forest would lead to a decrease in soil $\mathrm{pH}$, along with a decline in soil and foliar $\mathrm{Ca}$ and $\mathrm{Mg}$ levels and $\mathrm{Ca}: \mathrm{Al}$ ratios, and that soil and foliar $\mathrm{Al}$ levels would increase. I also examined whether concurrent additions of dolomitic limestone mitigated these effects at the soil or foliar level. 


\subsection{Methods.}

This study was done in the Fernow Experimental Forest Long Term Soil Productivity (LTSP) plots near Parsons, WV (39 $\left.04^{\prime} \mathrm{N}, 79^{\circ} 41^{\prime} \mathrm{W}\right)$ (Adams et al., 2004). The location of the Fernow LTSP experiment has a SE aspect, and slopes between 15 and $31 \%$. It is situated in the Allegheny Mountain subsection of the Appalachian Physiographic Province and has an elevation range of $798-847 \mathrm{~m}$. Prior to the initiation of the experiment in 1996, the most recent logging activity occurred in $\sim 1910$, and most trees were $\sim 85$ years old. The forest community before the experiment started was classified as a central Appalachian mixed hardwood forest.

The Fernow LTSP experiment is a randomized block design containing four blocks each with four plots that receive different treatments (Fig. 3.1). Each treatment plot is 0.4 ha in size (60.9 $\mathrm{m}$ on a side) and includes a 7.6-m wide buffer strip in which no samples were collected. The sampled area in each plot (referred to as a "growth plot") is 0.2 ha in area. When the plots were established, a numbered grid of permanent stakes was added to facilitate plot location and consistent sampling (Adams et al., 2004). Pretreatment values for soil and foliar $\mathrm{Ca}, \mathrm{Mg}$, and Al values were reported by Adams et al. (2004).

The four treatments in the Fernow LTSP study are: (1) reference plots (UNCUT) that were last harvested around 1910, and that received no experimental manipulation as part of the Fernow LTSP study; (2) cut plots (WT) that were subjected to a whole-tree harvest in 1996 in which all aboveground biomass was removed; (3) cut and fertilized plots $(\mathrm{WT}+\mathrm{NS})$ that were whole-tree harvested in 1996 and since that time have received 
annual applications of $35 \mathrm{~kg} \mathrm{~N} / \mathrm{ha}$ as ammonium sulfate to enhance $\mathrm{N}$ inputs and accelerate soil acidification; and (4) cut, fertilized, and limed plots (WT+NS+LIME) that were treated the same as the WT+NS plots and that have also received dolomitic lime every other year at an annual rate of $22.5 \mathrm{~kg} \mathrm{Ca} / \mathrm{ha}$ and $11.6 \mathrm{~kg} \mathrm{Mg} / \mathrm{ha}$ since the initiation of the study.

In this study, I only considered the harvested plots (WT, WT+NS, and WT+NS+LIME) because I was concerned with the effects of acidic deposition on an aggrading forest and the potential for mitigation of these effects by additions of lime. All of these treatment plots underwent a whole tree harvest in 1996 (which was the second major logging event for the forest) and were allowed to regenerate naturally. These plots are located on soils derived from base poor parent materials and occur in a region with a history of acidic deposition and logging. Soils are classified as loamy-skeletal, mixed active, mesic typic Dystrudepts and the parent materials are sandstone colluvium, sandstone residuum, and weathered shale (Adam et al., 2004). I included plots receiving lime additions because liming should mitigate the negative effects of acidification and allow me the opportunity to distinguish the direct effects of $\mathrm{N}$ inputs from the indirect effects of soil acidification caused by fertilizer additions.

Two approaches were used to evaluate treatment effects on soil cations: 1) the analysis of extractable $\mathrm{Ca}^{2+}, \mathrm{Mg}^{2+}$, and $\mathrm{Al}^{3+}$ in soil samples; and 2) the measurement of cation availability using ion exchange resins in situ (resin available). Analysis of extractable nutrients on the soil exchange complex provides an estimate of stores of readily available 
nutrients. Resin available ions are thought to more closely simulate ion availability to plant roots, and thus provide an index of immediately plant-available nutrients (Szillery et al., 2006).

Soil samples were collected from 16 randomly selected locations in each plot in midsummer 2008. At each sampling location, one soil core (2.3 cm in diameter) was taken from the top $5 \mathrm{~cm}$ of the A horizon. These 16 samples per plot were randomly pooled into four composite samples, each containing four soil cores. These four composite samples per plot were then sieved to pass a 2-mm mesh, and subsamples were used to measure soil $\mathrm{pH}$ and extractable ions.

The $\mathrm{pH}$ of each soil sample was measured in 0.01M calcium chloride (McClean 1982) after making a slurry using field moist subsamples. Soil extracts were made by mixing $2.5 \mathrm{~g}$ of air-dried soil with $25 \mathrm{ml}$ of $1.0 \mathrm{M}$ ammonium acetate in a $50-\mathrm{ml}$ centrifuge tube and shaking for 1 hour. Following this extraction period the soil/ammonium acetate mixture was centrifuged and the supernatant filtered and stored in at $4^{\circ} \mathrm{C}$ for later analysis (Carter 1993).

Cation availability was estimated on two occasions during mid-summer of 2006 using buried cation exchange resin strips. For each sampling event, ten randomly placed resin strips per plot were buried and allowed to remain in place for 2 weeks. The exchange resins were cut into identical strips $(25 \times 50 \mathrm{~mm})$ and had a marker-string attached to them through a 6-mm diameter hole. Prior to being placed in the field, all resin strips 
were cleaned and charged according to the protocol recommended by Western Ag Innovations (2006). At each location where a resin strip was to be buried, a narrow putty knife was used to make a vertical slit in the soil and the strips were inserted such that the top was $0.5-1.5 \mathrm{~cm}$ below the surface of the mineral soil with the marker-string exposed above the litter layer. Contact between each resin strip and the soil was assured by pushing the soil in around the strip, and the area surrounding it was moistened with deionized water. After being left in the field for 2 weeks, all resin strips were retrieved and as much soil as possible was brushed off. Resin strips were then washed free of all soil using deionized water, and all resin strips from each sampling run in each plot were eluted together in $100 \mathrm{ml}$ of $0.5 \mathrm{M} \mathrm{HCl}$ following the protocol of Western Ag Innovations (2006). All eluents were then filtered and stored at $4^{\circ} \mathrm{C}$ until their ion concentrations were analyzed.

Foliar cation concentrations were measured on leaves collected from two dominant tree species and one widely dispersed herb: yellow poplar (Liriodendron tulipifera) (LITU); pin cherry (Prunus pensylvanica) (PRPE); and round-leaved violet (Viola rotundifolia) (VIRO). Leaf samples were collected from all 3 species in mid-summer of 2006 at four randomly selected points in each plot. At each sampling point, 3 leaves were collected from the closest suitable plant of each of the 3 species. For L. tulipifera, understory trees that were $2.5 \mathrm{~cm}$ to $5 \mathrm{~cm}$ in diameter were sampled, and leaves were selected by taking the third leaf back from the meristem from 3 different branches. If necessary leaves were taken from more than one L. tulipifera tree. For P. pensylvanica, a small branch or piece of a branch was cut from the lower part of the canopy using a pole pruner, and 3 leaves 
were randomly selected. For $V$. rotundifolia, leaves were taken from more than one plant, if necessary. In all cases, only leaves with little insect damage were selected, and all dirt was brushed from the surface of the leaves and the petioles were cut off.

All leaves were dried in a $65^{\circ} \mathrm{C}$ drying oven for at least 48 hours. When all foliage samples were dry, the leaves for each species were pooled for each plot, weighed, and then ground to pass a \#20 mesh using a Wiley mill. This resulted in a single composite sample of ground leaves for each species for every plot that was sampled.

Approximately $0.2 \mathrm{~g}$ of tissue from each composite sample was then digested in nitric acid, with additions of hydrogen peroxide, using a Westco Scientific Instruments AD4020 block and following the procedure of Jones and Case (1990). The resulting digestate was then filtered and stored at $4^{\circ} \mathrm{C}$ until analysis of cations could be performed.

All soil extracts, resin eluents, and foliar digestates were analyzed for $\mathrm{Ca}^{2+}, \mathrm{Mg}^{2+}$, and $\mathrm{Al}^{3+}$ by atomic absorption spectroscopy using a Varian Spectra AA 220 FS Atomic Absorption Spectrometer. $\mathrm{Ca}^{2+}$ and $\mathrm{Mg}^{2+}$ were measured using flame absorption, and $\mathrm{Al}^{3+}$ was analyzed using a graphite-tube atomizer (Varian, 1989). The soil and ground foliage samples were also analyzed for their N concentration using a Carlo Erba NA 1500 N,C,S elemental analyzer.

To assess the significance of treatment effects, I used analysis of variance (ANOVA) to determine if increasing $\mathrm{N}$ inputs altered the soil or foliar chemistry. For each variable measured, I set up a two-way ANOVA with the factors in the statistical model being 
treatment and block (no treatment*block interaction term was included due to lack of replication at this level). Each plot was considered to be a single replicate and the average value for each variable was used for each plot, thus $n=4$. If significant effects for either factor were found, then post-hoc Tukey-Kramer tests were run. An alpha level of 0.05 was used throughout to assess statistical significance, and p-values between 0.05 and 0.10 were considered to be trends. Assumptions of ANOVA, including normality of residuals and homogeneity of variances were tested, and any necessary transformations were performed. All statistical tests were performed using SAS JMP version 10 (JMP).

\subsection{Results.}

After 10 years of continuous treatment, soil $\mathrm{pH}$ in the upper A horizon of WT+NS plots $(\mathrm{pH}=3.76)$ was lower $(\mathrm{p}=0.011)$ than that of $\mathrm{WT}(\mathrm{pH}=4.12)$ or $\mathrm{WT}+\mathrm{NS}+\mathrm{LIME}$ plots $(\mathrm{pH}=4.01)$ (Fig. 3.2). Soil extractable $\mathrm{Ca}^{2+}$ and $\mathrm{Al}^{3+}$ were not significantly affected by treatment $\left(\mathrm{p}=0.237, \mathrm{p}=0.119\right.$, respectively), but extractable $\mathrm{Mg}^{2+}$ was $(\mathrm{p}=0.041)$. Levels of extractable $\mathrm{Mg}^{2+}$ were $134 \%$ higher in $\mathrm{WT}+\mathrm{NS}+$ LIME plots than in $\mathrm{WT}+\mathrm{NS}$ plots and did not differ in any other comparison (Fig. 3.3). There was no effect of treatment on soil $\mathrm{N}$, which ranged between 0.329 and $0.341 \%$ (Table A.1) $(\mathrm{p}=0.805)$.

Resin available available $\mathrm{Ca}^{2+}, \mathrm{Mg}^{2+}$, and $\mathrm{Al}^{3+}$, as measured by ion exchange resins, were significantly affected by the treatments $(\mathrm{p}=0.016, \mathrm{p}=0.005, \mathrm{p}=0.032$, respectively). For this index of plant-available $\mathrm{Ca}^{2+}$, the values in plots treated with lime (WT+NS+LIME plots) were $93 \%$ greater than that those in plots receiving only additions of ammonium 
sulfate (WT+NS plots); and no other significant differences could be detected (Fig. 3.3). The availability of $\mathrm{Mg}^{2+}$ was about double in plots receiving lime additions (WT+NS+LIME plots) but no difference could be detected for $\mathrm{Mg}^{2+}$ resin availability between untreated plots and plots that received only additions of ammonium sulfate (Fig. 3.3). With respect to the resin availability of $\mathrm{Al}^{3+}$, I found the levels to be $93 \%$ higher in plots receiving only additions of ammonium sulfate (WT $+\mathrm{NS}$ plots) when compared to untreated plots (WT plots), but no other significant differences were detected (Fig. 3.3).

Foliar Ca concentrations in L. tulipifera and P. pensylvanica exhibited trends towards lower levels in the $\mathrm{WT}+\mathrm{NS}$ plots $(\mathrm{p}=0.064, \mathrm{p}=0.063$, respectively), but were not different in the WT+NS+LIME plots, when compared to the WT plots (Fig. 3.4). In contrast, no treatment effects were detected in the foliar Ca concentrations of $V$. rotundifolia ( $\mathrm{p}=0.453)$ (Fig. 3.4). Treatment effects on foliar Mg concentrations were seen for $L$. tulipifera, $P$. pensylvanica, and $V$. rotundifolia $(\mathrm{p}=0.013, \mathrm{p}=0.004, \mathrm{p}=0.014$, respectively) (Fig. 3.4). In each case, foliar Mg was higher in WT+NS+LIME plots when compared to either WT or WT+NS plots, which were not different from one another (Fig 3.4). No treatment effects on foliar Al concentrations could be detected for L. tulipifera, $P$. pensylvanica, and $V$. rotundifolia $(\mathrm{p}=0.133, \mathrm{p}=0.606, \mathrm{p}=0.170$, respectively) (Fig. 3.4). Finally, for each species examined, there was a significant treatment effect (or trend) on foliar N concentrations with levels being about $20 \%$ lower in the untreated plots (WT plots) than those found in plots receiving ammonium sulfate, with or without additions of lime (Fig. 3.4) (P. pensylvanica $(\mathrm{p}=0.002) ;$ L. tulipifera $(\mathrm{p}=0.055)$; and $V$. rotundifolia $(\mathrm{p}=0.028))$. 
Ratios of soil Ca to Al measurements of resin available ions (plant available, by proxy) showed a weak trend toward being affected by the treatments $(p=0.105)$ with $W T+N S$ plots having a lower ratio than WT plots but not lower than WT+NS+LIME plots, which also did not differ from WT plots (Fig. 3.5). A similar pattern of treatment effects on foliar Ca to Al ratios was found in leaves from L. tulipifera $(\mathrm{p}=0.080)($ Fig. 3.5). However soil $\mathrm{Ca}$ to $\mathrm{Al}$ ratios in the extractable pool measurements $(\mathrm{p}=0.354)$ or foliar measurements in $P$. pensylvanica or $V$. rotundifolia did not differ due to treatment $(\mathrm{p}=0.162, \mathrm{p}=0.193$, respectively) (Fig. 3.5). Soil Ca to Al ratios ranged from 1.27 to 11.79, and foliar Ca to Al ratios ranged from 13.52 to 101.33 (Table 3.2).

There were no significant deviations from normality in the distributions of the residuals of any statistical model, so no transformations were needed. There were only two variables with significant block effects: soil $\% \mathrm{~N}$ and soil resin available $\mathrm{Ca}^{2+}(\mathrm{p}=0.003$, $\mathrm{p}=0.033$, respectively). For both of these variables, post-hoc testing indicated greater $\mathrm{N}$ and Ca values at the top of the slope in Block 1 compared to blocks lower on the slope.

\subsection{Discussion.}

After 10-12 years of adding ammonium sulfate to an aggrading temperate deciduous forest, a variety of changes were observed, suggesting that continued ammonium sulfate additions could diminish the future extent and duration of any fertilizer-induced stimulation in aboveground growth. Specifically, I found decreased soil $\mathrm{pH}$, decreased 
foliar Ca concentration in L. tulipifera and P. pensylvanica, decreased resin available soil Ca: $\mathrm{Al}$ ratios and foliar Ca:Al ratios in L. tulipifera, and increased resin available Al. Furthermore, these changes were largely consistent with the postulated outcomes of acidification from inputs of elevated levels of $\mathrm{N}$ and $\mathrm{S}$ (Aber et al., 1998; Fernandez et al., 2003).

Adding dolomitic limestone concurrently with the ammonium sulfate mitigated some of the negative effects - particularly those on soil $\mathrm{pH}$ and foliar $\mathrm{Ca}$ in $P$. pensylvanica, as well as increasing resin available soil $\mathrm{Ca}^{2+}$ and $\mathrm{Mg}^{2+}$, extractable soil $\mathrm{Mg}^{2+}$, and foliar $\mathrm{Mg}$ in all species measured. Surprisingly, however, despite its ability to mitigate the effects of ammonium sulfate on soil $\mathrm{pH}$, dolomitic limestone additions failed to alter levels of soil Al.

In addition to these statistically detectable responses, there was an overarching and coherent pattern in the mean response of each variable to the treatments in the Fernow LTSP that was consistent with expectations based on previous studies. The mean value for soil $\mathrm{pH}$, resin available $\mathrm{Ca}^{2+}$ and $\mathrm{Mg}^{2+}$, and extractable $\mathrm{Ca}^{2+}$ and $\mathrm{Mg}^{2+}$ was always lower in WT+NS plots than in either the WT or WT+NS+LIME plots, and the mean value for resin available or extractable $\mathrm{Al}^{3+}$ was higher in $\mathrm{WT}+\mathrm{NS}$ plots than in either WT or WT+NS+LIME plots (Fig. 3.2, Fig. 3.3). Furthermore, the mean value for foliar $\mathrm{Ca}$ and $\mathrm{Mg}$ concentrations was always lower in $\mathrm{WT}+\mathrm{NS}$ plots than in WT or WT+NS+LIME, regardless of species (Fig. 3.4). And finally, the mean Ca to Al ratio was always lower in $\mathrm{WT}+\mathrm{NS}$ plots than either WT or WT+NS+LIME plots, regardless of 
the measurement (soil or plant) upon which it was based (Fig. 3.5). Again, these differences were not all statistically detectable, but the patterns were consistent.

The apparent pattern visible in all variables measured agreed with the predictions associated with soil acidification and $\mathrm{Ca}$ and $\mathrm{Mg}$ leaching due to elevated $\mathrm{N}$ and $\mathrm{S}$ deposition. The pattern also suggested that liming could potentially mitigate some, but not all of the acidification induced soil changes. That this pattern was not always statistically detectable and that overall tree growth has shown an increase independent of acidification (Fowler et al., unpublished) indicated that soil acidification and base cation leaching may be in their early stages in the Fernow LTSP plots. Other researchers have indicated that foliar $\mathrm{Ca}$ and $\mathrm{Mg}$ levels are correlated with soil availability of these nutrients (Lucash et al., 2012; Miller and Watmough, 2009), and also that it is possible to see such a pattern without the trees being affected negatively (Miller and Watmough, 2009).

The general pattern in soil and foliar $\mathrm{Ca}$ and $\mathrm{Mg}$ could also be attributable to depletion of soil reserves by the increased tree growth and forest floor depth that was observed in the plots receiving additions of ammonium sulfate (Fowler et al., unpublished). Indeed, accumulation in tree growth and accumulation in the forest floor have been found to be important sinks for $\mathrm{Ca}$ and $\mathrm{Mg}$ in other forests (Adams et al., 2004; Huntington et al., 2000; Huntington, 2000; Federer et al., 1989). However, such an explanation seems unlikely in this case given that the amount of soil Ca depletion per unit of $\mathrm{N}$-induced biomass increase in the acidified WT+NS plots versus the WT plots was $>10 \mathrm{x}$ the ratio 
of soil Ca depletion per unit of biomass increase after 13 years of growth in the cut plots that received no ammonium sulfate additions (WT plots); suggesting that most of the Ca depletion from soils caused by ammonium sulfate additions is attributable to factors other than greater amounts of storage in the forest floor and tree growth. Furthermore, if Al were subject to the same effect, then I wouldn't have observed a change in the ratio of soil Ca to Al.

Values found for soil and foliar $\mathrm{Ca}$ and $\mathrm{Mg}$ were similar to values found in multiple studies including the Bear Brook Watershed N addition study (Elvir et al., 2006, Fernandez et al., 2003), Hubbard Brook Experimental Forest (Juice et al., 2006), deciduous forests in Ontario and Quebec (Houle et al., 2007; Miller and Watmough, 2009), and in the watershed of the Cherry River in WV (Farr et al., 2009). Soil Al values in this current study seemed low when compared to the pretreatment values for the same site $\left(\sim 0.120 \mathrm{cmol}_{\mathrm{c}} / \mathrm{kg}\right.$ vs. $\left.3.52 \mathrm{cmol}_{\mathrm{c}} / \mathrm{kg}\right)$. However, reported values for soil Al levels using similar methods in a nearby watershed acidification study at the Fernow (WS 3) were highly variable and range from $0.015 \mathrm{cmol}_{\mathrm{c}} / \mathrm{kg}$ (Pickens, 1995) to $\sim 0.2-\sim 0.5$ cmolc/kg (Odenwald, 2002) to $\sim 1.75 \mathrm{cmol}_{\mathcal{c}} / \mathrm{kg}$ (Tepp, 1995). One side effect of these very low soil $\mathrm{Al}$ values was that my soil $\mathrm{Ca}$ :Al ratios were all very high and well out of the range for concern suggested by Cronan and Grigal (1995).

Although there were no indications of negative effects on cumulative tree growth during the first 13 years of accelerated acidification at the Fernow LTSP plots, and, in fact, growth has increased (Fowler et al., unpublished), soils such as those at the Fernow are 
quite susceptible to the impacts of acidification due to the low $\mathrm{Ca}$ and $\mathrm{Mg}$ content in parent material (Adams et al., 1997; Huntington et al., 2000) and multiple logging episodes (Adams et al., 2000). Additionally, once acidification begins in such soils, its effects on soil nutrient pools may be long-lasting, even after elevated inputs of acidifying agents has ceased.

The results from this study are complemented by observations from a nearby, watershedlevel acidification study that involves the addition of ammonium sulfate (at the same rate used in the LTSP study) to a more mature, but otherwise similar forest (Kochederfer, 2006). In this ongoing experiment, annual additions of ammonium sulfate began in 1989 - 19 years after the watershed (WS 3) had been clearcut. Similar to the LTSP experiment, the annual additions of ammonium sulfate to WS 3 increased tree growth but this enhanced growth was species-specific and lasted for only $\sim 7$ years before a decline in growth rates, or a diminished growth enhancement, occurred (DeWalle et al., 2006). And when the soils in WS 3 were compared to soils in a nearby watershed with trees of a similar age (WS 7), it was found that the acidified watershed had A-horizon soils with a lower $\mathrm{pH}$, a lower concentration of extractable $\mathrm{Ca}$, a higher level of extractable $\mathrm{Al}$, and a lower Ca to Al ratio (Adams et al. 2006). Thus, it seems likely, based on soil and foliar nutrient responses I measured in the Fernow LTSP study, that after 13 years of ammonium sulfate additions a shift in growth response of trees may be imminent or already occurring. Since I previously measured cumulative tree growth, such a shift in growth response could be masked for several years by an early increase in growth rate. It also seems likely that the duration of the increase in growth in the Fernow LTSP study 
would be longer than that in the watershed acidification study because the forest in the Fernow LTSP was younger and, therefore, more likely to be N limited.

Acidification-induced changes in soil pools of $\mathrm{Ca}, \mathrm{Mg}$, and $\mathrm{Al}$ have been found to affect trees in various negative ways. Sugar maple (Acer saccharum), in particular, can be sensitive to acidic deposition (Duchesne et al., 2002; Horsley et al., 2000; Houle et al, 2007). Additionally both A. saccharum and red spruce (Picea rubens) have been found to respond positively to $\mathrm{Ca}$ additions in areas with high acidic deposition (Halman et al., 2008; Juice et al., 2006). Even before overall tree growth is negatively affected by acidic deposition, changes in soil nutrient levels can lead to differential effects on different species (Fowler et al, unpublished; McNeil et al., 2007; Zaccherio and Finzi, 2007), which may lead to changes in tree species composition and, potentially, ecosystem services. Evidence of the onset of acidification at the Fernow LTSP plots is, therefore important to note and follow into the future. In fact, continued depletion of soil $\mathrm{Ca}$ and Mg has the potential to reverse the growth increase seen thus far in the Fernow LTSP plots.

Despite a lack of negative effects on the initial 13 years of cumulative tree growth in the LTSP experiment (Fowler, unpublished), I found chemical changes in soil and foliage after continual ammonium sulfate additions to young forest stands that indicated the onset of soil acidification and $\mathrm{Ca}$ and $\mathrm{Mg}$ depletion. When compared to the findings from a similar experiment in a nearby watershed, these results suggest that continued acidification will constrain the magnitude and duration of any initial enhancement to tree 
growth and aboveground $\mathrm{C}$ storage. Additionally, I found that liming may be a potential way to mitigate some of the negative impacts of acidification for experimental or management purposes. 


\subsection{Tables and Figures.}

Figure 3.1. The Fernow Experimental Forest Long Term Soil Productivity (LTSP) plots showing blocking and treatment distribution (Adams et al., 2004).

\begin{tabular}{|c|c|c|c|c|}
\hline \multicolumn{4}{|c|}{ Top of slope } & \multirow[b]{2}{*}{ Block 1} \\
\hline $\begin{array}{c}\text { Plot } 4 \\
\text { UNCUT }\end{array}$ & $\begin{array}{l}\text { Plot } 3 \\
\text { WT }\end{array}$ & $\begin{array}{c}\text { Plot } 2 \\
\text { WT+NS+ } \\
\text { LIME }\end{array}$ & $\begin{array}{c}\text { Plot } 1 \\
\text { WT+NS }\end{array}$ & \\
\hline $\begin{array}{l}\text { Plot } 5 \\
\text { WT }\end{array}$ & $\begin{array}{c}\text { Plot } 6 \\
\text { WT+NS }\end{array}$ & $\begin{array}{c}\text { Plot } 7 \\
\text { WT+NS+ } \\
\text { LIME }\end{array}$ & $\begin{array}{l}\text { Plot } 8 \\
\text { UNCUT }\end{array}$ & \multirow[t]{4}{*}{ Block 2} \\
\hline $\begin{array}{l}\text { Plot } 12 \\
\text { WT }\end{array}$ & $\begin{array}{l}\text { Plot } 11 \\
\text { UNCUT }\end{array}$ & $\begin{array}{l}\text { Plot } 10 \\
\text { WT+NS }\end{array}$ & $\begin{array}{c}\text { Plot } 9 \\
\text { WT+NS+ } \\
\text { LIME }\end{array}$ & \\
\hline $\begin{array}{l}\text { Plot } 13 \\
\text { WT+NS }\end{array}$ & $\begin{array}{l}\text { Plot } 14 \\
\text { WT+NS+ } \\
\text { LIME }\end{array}$ & $\begin{array}{l}\text { Plot } 15 \\
\text { WT }\end{array}$ & $\begin{array}{l}\text { Plot } 16 \\
\text { UNCUT }\end{array}$ & \\
\hline \multicolumn{4}{|c|}{ Bottom of slope } & \\
\hline
\end{tabular}


Figure 3.2. Mean soil $\mathrm{pH}$ in $0.1 \mathrm{M} \mathrm{CaCl}_{2}$ after 12 years of treatment. Error bars represent one standard error above and below the mean. Bars separated by different letters are significantly different at $\mathrm{p}<0.05$ in post hoc analysis.

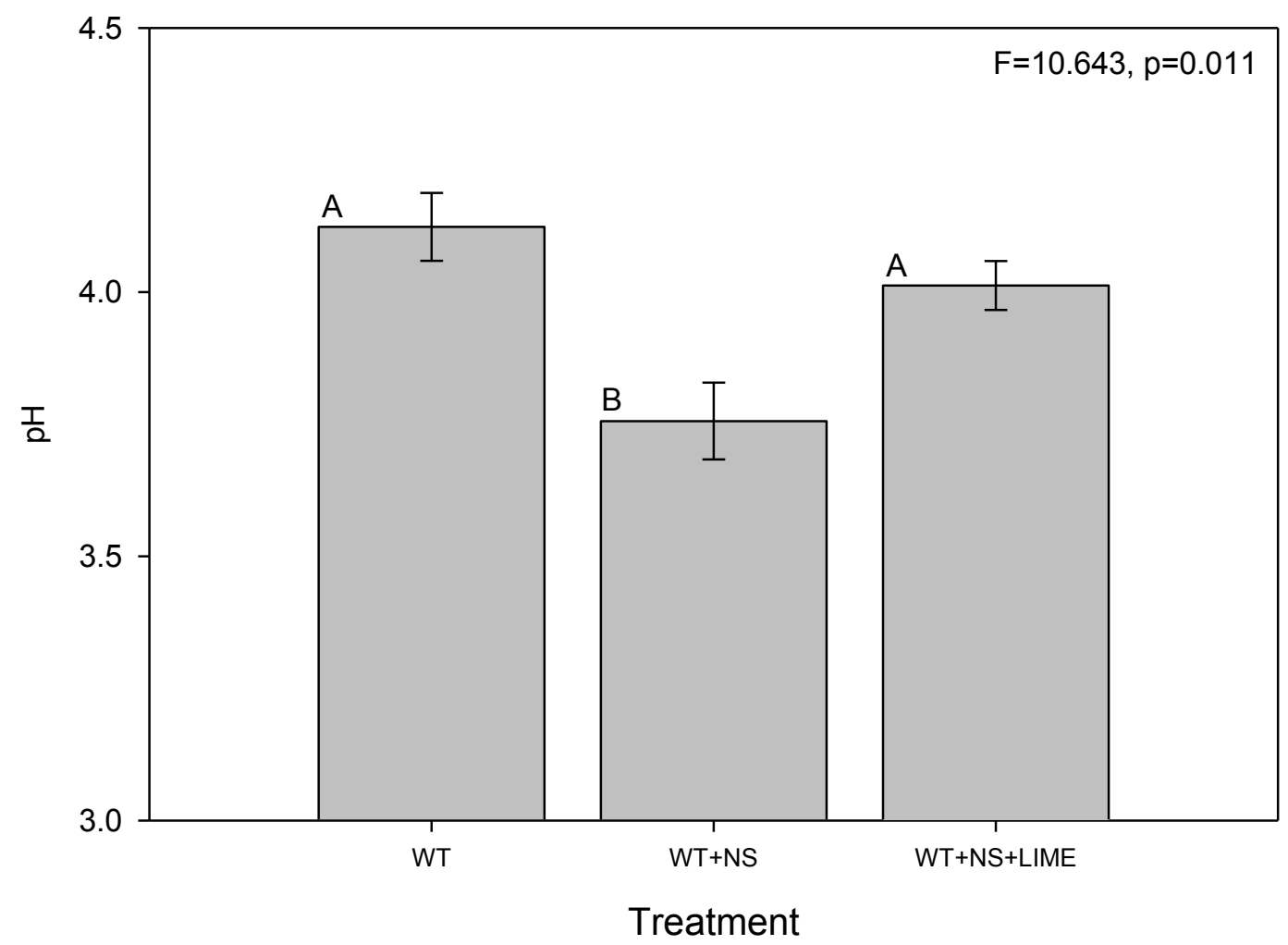


Figure 3.3. Mean soil chemistry measurements after 10 (resin) and 12 (extractable) years of treatment. Error bars represent one standard error above and below the mean. Bars separated by different letters are significantly different at $\mathrm{p}<0.05$ in post hoc analyses.

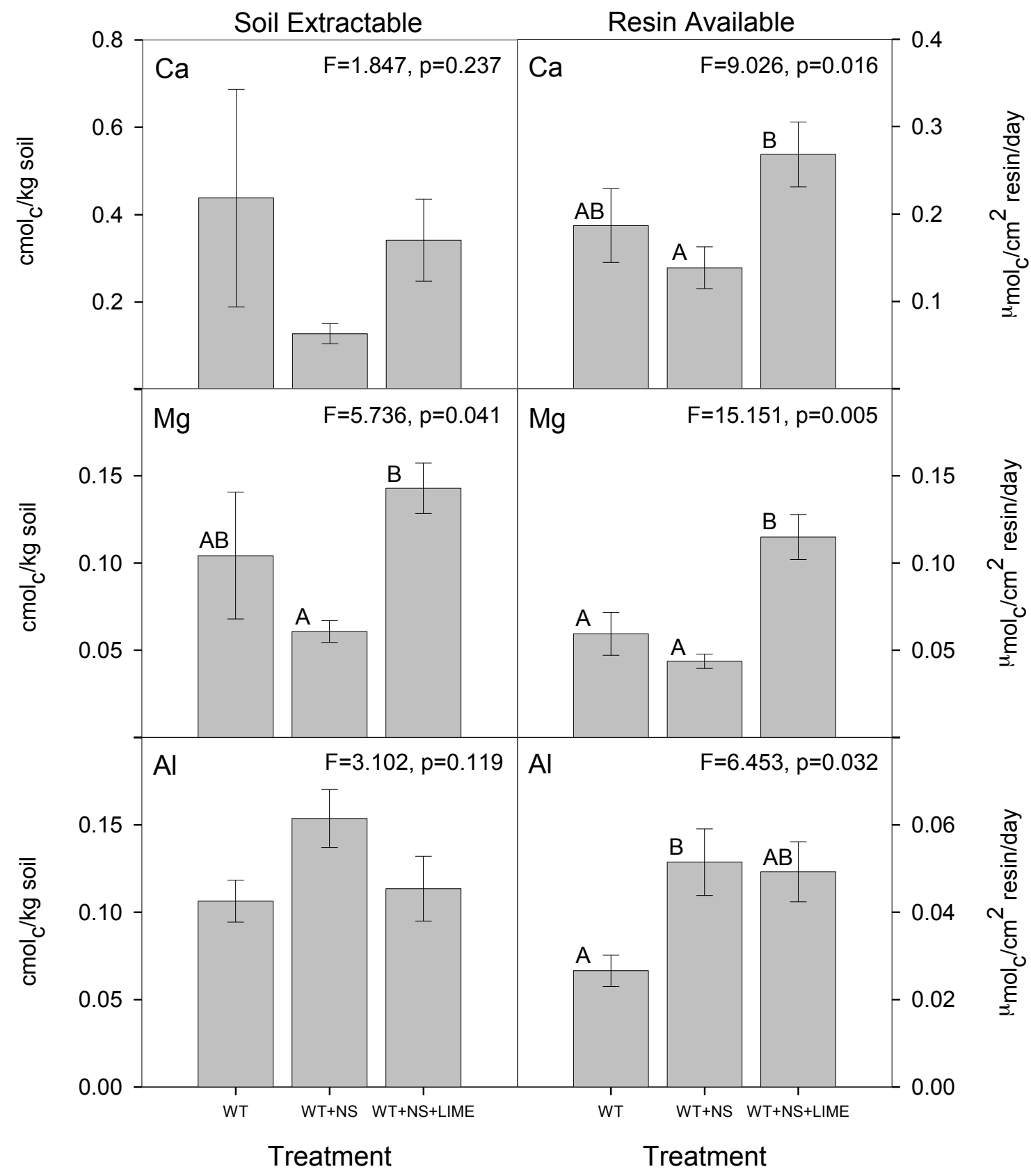


Figure 3.4. Mean values for foliar chemistry after 10 years of treatment. Error bars represent one standard error above and below the mean. Values separated by different capital letters are significantly different at $\mathrm{p}<0.05$, and those separated by lowercase letters show a trend towards differences at $\mathrm{p}<0.1$ in post hoc analyses. (LITU $=$ Liriodendron tulipifera, $\mathrm{PRPE}=$ Prunus pensylvanica, $\mathrm{VIRO}=$ Viola rotundifolia $)$

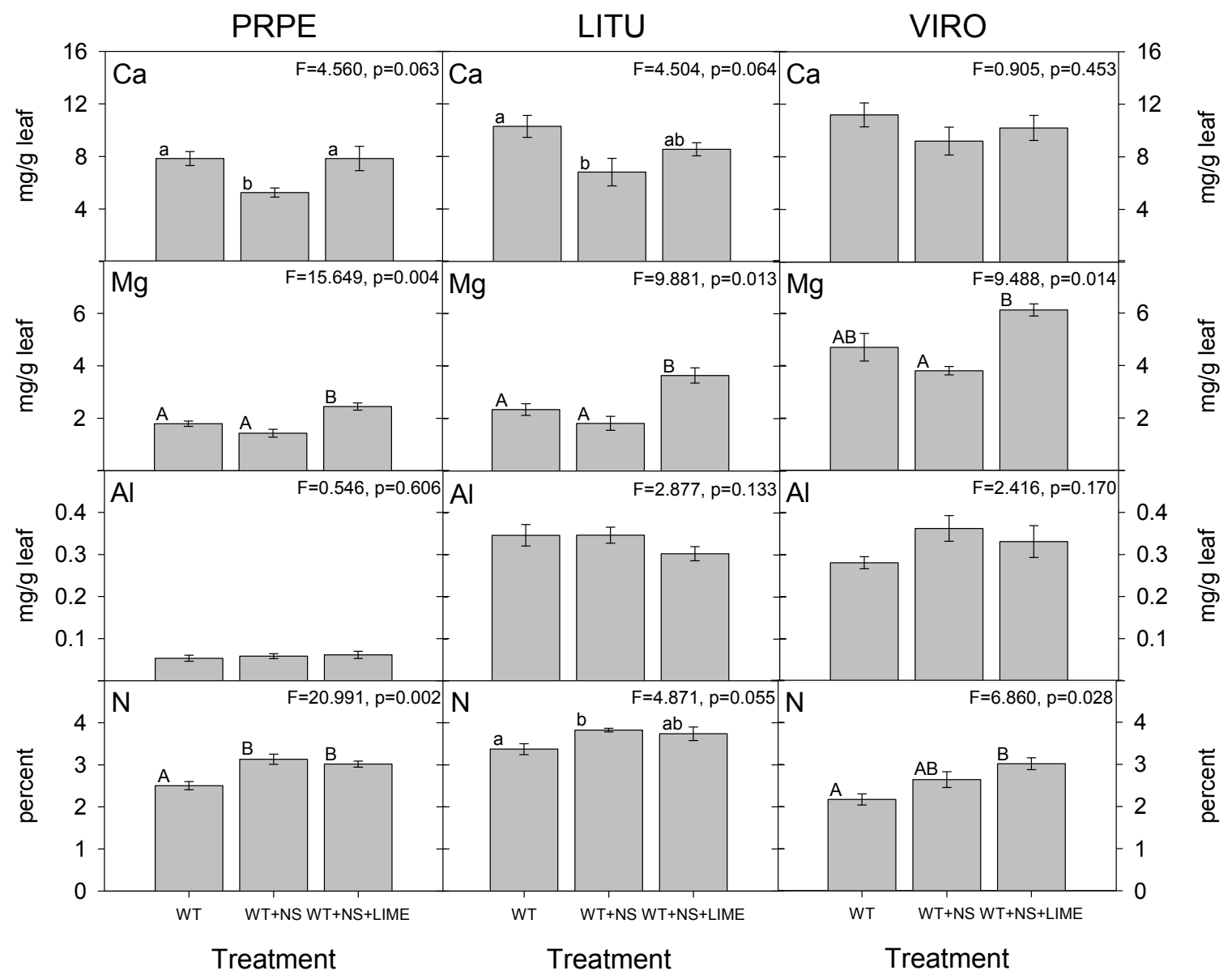


Figure 3.5. Mean values for $\mathrm{Ca}$ :Al ratios after 10 (foliar and resin available) -12 (exchangeable) years of treatment. Error bars represent one standard error above and below the mean. Values separated by lowercase letters show a trend towards differences at $\mathrm{p}<0.1$ in post hoc analyses. (LITU $=$ Liriodendron tulipifera, $\mathrm{PRPE}=$ Prunus pensylvanica, VIRO $=$ Viola rotundifolia $)$

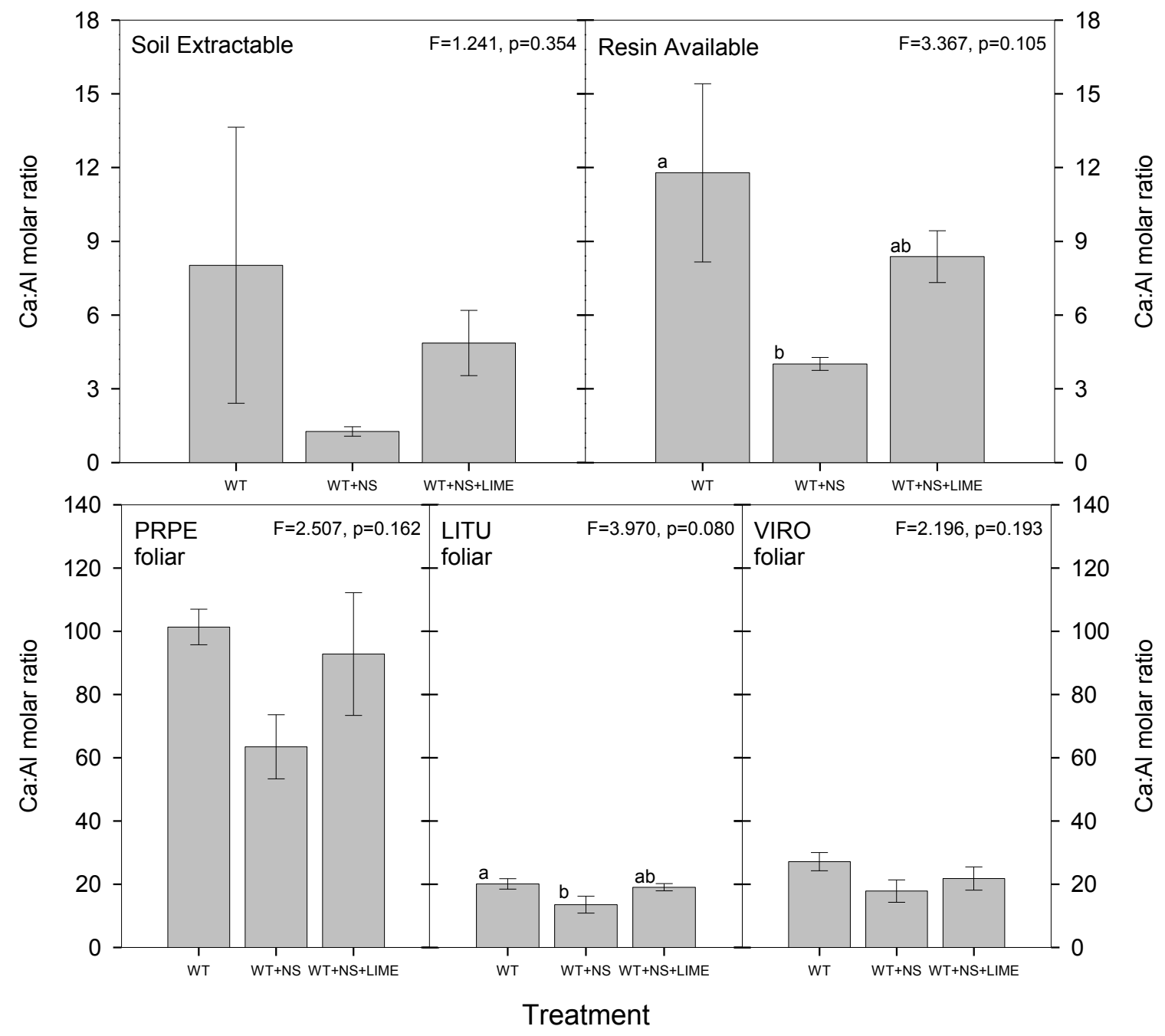




\subsection{Literature Cited.}

Aber, J. D., K. J. Nadelhoffer, P. Steudlar, and J. M. Mellilo. 1989. Nitrogen saturation in northern forest ecosystems. BioScience 39: 378-386.

Aber, J. D., W. McDowell, K. Nadelhoffer, A. Magill, G. Berntson, M. Kamakea, S. McNulty, W. Currie, L. Rustad, and I. Fernandez. 1998. Nitrogen saturation in temperate forest ecosystems. BioScience 48: 921-934.

Adams, M. B., T. R. Angradi, and J. N. Kochenderfer. 1997. Stream water and soil solution responses to 5 years of nitrogen and sulfur additions at the Fernow Experimental Forest, West Virginia. Forest Ecology and Management 95: 79-91.

Adams, M. B., J. A. Burger, A. B. Jenkins, and L. Zelazny. 2000. Impact of harvesting and atmospheric pollution on nutrient depletion of eastern US hardwood forests. Forest Ecology and Management 138: 301-319.

Adams, M. B., J. Burger, L. Zelazny, and J. Baumgras. 2004. Description of the Fork Mountain long-term soil productivity study: site characterization. USDA Forest Service, Newtown Square, PA.

Adams, M. B., D. R. DeWalle, W. T. Peterjohn, F. S. Gilliam, W. E. Sharpe, and K. W. J. Williard. 2006. Vegetation and acidification. In: M. B. Adams et al. (eds.), Soil chemical response to experimental acidification treatments. Springer, The Netherlands: 41-69.

Carter, M. R., Ed. 1993. Soil sampling and methods of analysis. Canadian Society of Soil Science. Lewis Publishers, Boca Raton, FL.

Cronan, C. S. and D. F. Grigal. 1995. Use of calcium/aluminum ratios as indicators of stress in forest ecosystems. Journal of Environmental Quality 24: 209-226.

DeWalle, D. R., J. L. Hom, and M. B. Adams. 2006. Introduction to the Fernow watershed acidification study. In: M. B. Adams et al. (eds.), The Fernow watershed acidification study. Springer, The Netherlands: 1-16.

DeWalle, D. R., J. N. Kochenderfer, M. B. Adams, G. W. Miller, F. S. Gilliam, F. Wood, S. S. Odenwald-Clemens, and W. E. Sharpe. 2006. Vegetation and acidification. In: M. B. Adams et al. (eds.), The Fernow watershed acidification study. Springer, The Netherlands: 1-16.

Driscoll, C. T., G. B. Lawrence, A. J. Bulger, T. J. Butler, C. S. Cronan, C. Eagar, K. F. Lambert, G. E. Likens, J. L. Stoddard, and K. C. Weathers. 2001. Acidic deposition in the Northeastern United States: Sources and inputs, ecosystem effects, and management strategies. BioScience 51: 180-198. 
Duchesne, L., R. Ouimet, and D. Houle. 2002. Basal area growth of sugar maple in relation to acid deposition, stand health, and soil nutrients. Journal of Environmental Quality 31: 1676-1683.

Elser, J. J., M. E. S. Bracken, E. E. Cleland, D. S. Gruner, W. S. Harpole, H. Hillebrand, J. T. Ngai, E. W. Seabloom, J. B. Shurin, and J. E. Smith. 2007. Global analysis of nitrogen and phosphorus limitation of primary producers in freshwater, marine and terrestrial ecosystems. Ecology Letters 10: 1135-1142.

Elvir, J. A., G. B. Wiersma, M. E. Day, M. S. Greenwood, and I. J. Fernandez. 2006. Effects of enhanced nitrogen deposition on foliar chemistry and physiological processes of forest trees at the Bear Brook Watershed in Maine. Forest Ecology and Management 221: 207-214.

Farr, C., J. Skousen, P. Edwards, S. Connolly, and J. Sencindiver. 2009. Acid soil indicators in forest soils of the Cherry River Watershed, West Virginia. Environmental Monitoring and assessment 158: 343-353.

Federer, C. A., J. W. Hornbeck, L. M. Tritton, C. W. Martin, and R. S. Pierce. 1989. Long-term depletion of calcium and other nutrients in Eastern US forests. Environmental Management 13: 593-601.

Fernandez, I. J., L. E. Rustad, S. A. Norton, J. S. Kahl, and B. J. Cosby. 2003. Experimental acidification causes soil base-cation depletion at the Bear Brook Watershed in Maine. Soil Society of America Journal 67: 1909-1919.

Fenn, M. E., M. A. Poth, J. D. Aber, J. S. Baron, B. T. Bormann, D. W. Johnson, A. D. Lemly, S. G. McNulty, D. F. Ryan, and R. Stottlemyer. 1998. Nitrogen excess in North American ecosystems: Predisposing factors, ecosystem responses, and management strategies. Ecological Applications 8: 706-733.

Halman, J. M., P. G. Schaberg, G. J. Hawley, and C. Eagar. 2008. Calcium addition at the Hubbard Brook Experimental Forest increases sugar storage, antioxidant activity and cold tolerance in native red spruce (Picea rubens). Tree Physiology 28: $855-862$.

Hogberg, P., H. Fan, M. Quist, D. Binkley, and C. O. Tamm. 2006. Tree growth and soil acidification in response of 30 years of experimental nitrogen loading on boreal forest. Global Change Biology 12: 489-499.

Horsley, S. B., R. P. Long, S. W. Bailey, R. A. Hallet, and T. J. Hall. 2000. Factors associated with the decline disease of sugar maple on the Allegheny Plateau. Canadian Journal of Forest Research 30: 1365-1378. 
Houle, D., S. Tremblay, and R. Ouimet. 2007. Foliar and wood chemistry of sugar maple along a gradient of soil acidity and stand health. Plant and Soil 300: 173183.

Huntington, T. G., R. P. Hooper, C. E. Johnson, B. T. Aulenbach, R. Cappellato, and A. E. Blum. 2000. Calcium depletion in a Southeastern United States forest ecosystem. Soil Science Society of America Journal 64: 1845-1858.

Huntington, T. G. 2000. The potential for calcium depletion in forest ecosystems of Southeastern United States: Review and analysis. Global Biogeochemical Cycles 14: $623-638$.

JMP, Version 10. SAS Institute Inc., Cary, NC, 1989-2007.

Jones, J. B. and V. W. Case. 1990. Sampling, handling, and analyzing plant tissue samples. In: R. I. Westerman (Ed.), Soil testing and plant analysis. Soil Society of America, Madison, WI, p. 389-427.

Juice, S. M., T. J. Fahey, T. G. Siccama, C. T. Driscoll, E. G. Denny, C. Eagar, N. L. Cleavitt, R. Minocha, and A. D. Richardson. 2006. Response of sugar maple to calcium addition to northern hardwood forest. Ecology 87: 1267-1280.

Kochenderfer, J. N. 2006. Fernow and the Appalachian hardwood region. In: M. B. Adams et al. (eds.), The Fernow watershed acidification study. Springer, The Netherlands: 17-39.

Magill, A. H., M. R. Downs, K. J. Nadelhoffer, R. A. Hallett, and J. D. Aber. 1996. Forest ecosystem response to four years of chronic nitrate and sulfate additions at Bear Brooks Watershed, Maine, USA. Forest Ecology and Management 84: 2937.

Magill, A. H., J. D. Aber, W. S. Currie, K. J. Nadelhoffer, M. E. Martin, W. H. McDowell, J. M. Melillo, and P. Steudlar. 2004. Ecosystem response to 15 years of chronic nitrogen additions at the Harvard Forest LTER, Massachusetts, USA. Forest Ecology and Management 196: 7-28.

McLean, E.O. 1982. Soil pH and lime requirement. In: Page, A.L., Miller, R.H., Keeney, D.R. (Eds.), Methods of soil analysis. Part 2. Chemical and microbiological properties, 2nd Edition. Agronomy 9, 199-224.

McNeil, B. E., J. M. Read, and C. T. Driscoll. 2007. Foliar nitrogen responses to elevated atmospheric nitrogen deposition in nine temperate forest canopy species. Environmental Science and Technology 41: 5191-5197. 
McNulty, S.G., J. Boggs, J.D. Aber, L. Rustad, and A. Magill. 2005. Red spruce ecosystem level changes following 14 years of chronic $\mathrm{N}$ fertilization. Forest Ecology and Management 219:279-291.

Miller, D. E. and S. A. Watmough. 2009. Soil acidification and foliar nutrient status of Ontario's deciduous forest in 1986 and 2005. Environmental Pollution 157: 664672.

Nadelhoffer, K. J., J. D. Aber, and J. M. Melillo. 1985. Fine roots, net primary production, and soil nitrogen availability: A new hypothesis. Ecology 66: 13771390.

Odenwald, S. S. 2002. Effects of watershed acidification on soil chemistry, radial growth, and bolewood chemistry of three hardwood species in West Virginia. M.S. thesis. The Pennsylvania State University. Summarized in: M. B. Adams et al. (eds.), The Fernow watershed acidification study. Springer, The Netherlands: 41-69.

Pickens, C. J. 1995. Early indicators of acidification: A whole watershed approach to studying forest response to additions of nitrogen and sulfur. Ph.D. dissertation. The Pennsylvania State University. Summarized in: M. B. Adams et al. (eds.), The Fernow watershed acidification study. Springer, The Netherlands: 41-69.

Pregitzer, K. S., A. J. Burton, D. R. Zak, and A. F. Talhelm. 2008. Simulated chronic nitrogen deposition increases carbon storage in northern temperate forests. Global Change Biology 14: 142-153.

Szillery, J. E., I. J. Fernandez, S. A. Norton, L. E. Rustad, and A. S. White. 2006. Using ion-exchange resins to study soil response to experimental watershed acidification. Environmental Monitoring and Assessment 116: 383-398

Tepp, J. S. 1995. Effects of soil ammonium sulfate applications on tree-ring chemistry in three diffuse-porous Appalachian hardwood species. M.S. thesis. The Pennsylvania State University. Summarized in: M. B. Adams et al. (eds.), The Fernow watershed acidification study. Springer, The Netherlands: 41-69.

Thomas, R. Q., C. D. Canham, K. C. Weathers, and C. L. Goodale. 2010. Increased tree carbon storage in response to nitrogen deposition in the US. Nature Geoscience 3: $13-17$.

Varian. 1989. Analytical methods. Varian Australia Pty Ltd. Mulgrave, Victoria, Australia.

Vitousek, P. M. and R. W. Howarth. 1991. Nitrogen limitation on land and in the sea how can it occur? Biogeochemistry 13: 87-115. 
Western Ag Innovations Inc. 2006. Use procedures for PRS-probes. Western Ag Innovations Inc., Saskatchewan, Canada.

Zaccherio, M. T. and A. T. Finzi. 2007. Atmospheric deposition may affect northern hardwood forest composition by altering soil nutrient supply. Ecological Applications 17: 1929-1941. 
Chapter 4. Accelerated soil acidification in an aggrading temperate forest may decrease millipede populations by a mechanism unrelated to changes in calcium availability. 


\subsection{Abstract.}

Soil and foliar nutrient changes caused by acidic deposition may possibly be transmitted into higher trophic levels due to their effects on litter-consuming invertebrates. Birds and other organisms depend on calcium-rich food sources (e.g. snails and millipedes) to meet their calcium $(\mathrm{Ca})$ requirements during critical times in their life cycles. Indeed, reductions in Ca-rich prey by acidic deposition has been identified as an important factor related to the decline in some bird species. With this in mind, I used the Fernow Experimental Forest Long Term Soil Productivity (LTSP) plots to study the effect of accelerated acidification in an aggrading temperate deciduous forest on populations of Pseudopolydesmus serratus, a litter processing millipede that contains high levels of Ca relative to other invertebrates. Previous work in the Fernow LTSP plots found patterns of declines in soil and foliar $\mathrm{Ca}$ levels after at least 10 years of ammonium sulfate additions and provided evidence that these declines may be mitigated by concurrent additions of dolomitic limestone. Therefore, I hypothesized declines in populations of these millipedes and mitigation of this decline with lime addition.

I found that the number and mass of $P$. serratus millipedes was reduced by $\sim 50 \%$ after 13 years of simulated acidic deposition. The negative effect of nitrogen $(\mathrm{N})$ addition on millipede populations, however, was not attributable to a depletion of $\mathrm{Ca}$ from the soil and plants, but seemed to be a more direct consequence of increasing soil or foliar $\mathrm{N}$. Interestingly, despite decreases in Ca-rich millipedes not being caused by $\mathrm{Ca}$ depletion in the soil environment, the potential still exists for consumers depending on this species for $\mathrm{Ca}$ to be affected by acid deposition. 


\subsection{Introduction.}

Acidic deposition is a major anthropogenic perturbation of ecosystems in the eastern United States and is caused mainly by a combination of nitric and sulfuric acids produced in the atmosphere from pollutants released by fossil fuel burning (Driscoll et al., 2001). One of the major impacts of acidic deposition is that it supplies ecosystems with biologically available forms of nitrogen $(\mathrm{N})$ and sulfur $(\mathrm{S})$ at greater than pre-industrial levels. In the United States, Clean Air Act legislation in 1970 led to stabilization of the concentrations of $\mathrm{N}$ and reductions in the concentrations of $\mathrm{S}$ in precipitation (Baumgardner et al., 2002), and more regulation in 1990 resulted in a decline in $\mathrm{N}$ concentrations and a continued decline in S concentrations (US EPA, 2013). Despite these improvements, the levels of $\mathrm{N}$ and $\mathrm{S}$ in precipitation in the US, especially in the east, are still above pre-industrial levels and are likely to remain so for some time. Additionally, in other forested parts of the world, especially Asia, levels of $\mathrm{N}$ and $\mathrm{S}$ in precipitation are likely to continue to rise in the future (Galloway et al., 2004; Dentener et al., 2006).

One expected result of long-term acidic deposition in temperate deciduous forests is $\mathrm{N}$ saturation followed by soil acidification and eventual depletion of soil calcium $(\mathrm{Ca})$ and magnesium (Mg) by leaching (Aber et al., 1998; Fernandez et al., 2003). This idea is supported by many independent studies including $\mathrm{N}$ addition studies in many forest types (Adams et al., 1997; Fernandez et al., 2003, Fernandez et al., 2010; Hogberg et al., 2006; Wallace et al., 2007), long term soil data in areas receiving different levels of acidic 
deposition (Bailey et al., 2005; Bedison and Johnson, 2010; Farr et al., 2009; Likens et al., 1996; Miller and Watmough, 2009), and modeling studies (Chen and Driscoll, 2004;

Gbondo-Tugbawa and Driscoll, 2003; Hruska et al., 2012).

Additionally, the impact of acidic deposition on the nutrient content in soils is likely to be mirrored in the tissues of plants growing in these soils and the leaf litter they produce. For instance, foliar $\mathrm{Ca}$ and $\mathrm{Mg}$ levels are often correlated with soil availability of these nutrients (Lucash et al., 2012; Miller and Watmough, 2009). Studies have found declines in foliar Ca levels with increasing acidic deposition in both gradient (Houle et al., 2007) and experimental addition studies (Elvir et al., 2006), as well as declines in the Ca levels of soil organic matter with time, attributed to acidic deposition (Johnson et al., 2008).

Changes in soil and foliar Ca levels may affect soil- and litter-dwelling invertebrates, particularly those with exoskeletons containing high levels of Ca. Several researchers have found that the number and species richness of snails is positively associated with the $\mathrm{pH}$ of soil, and with the Ca content of the soil and litter layer (Hotopp, 2002; Johannessen and Solhoy, 2001; Skeldon et al., 2007). Furthermore, Graveland and van der Wal (1996) tied declines in snail populations to acidic deposition through resultant soil Ca depletion.

This decline in a Ca-rich food source as a result of acidic deposition has the potential to affect multiple trophic levels in an ecosystem, and even the ecosystem as a whole (Schaberg et al., 2001). This is because these invertebrates can be important in the 
transmission of $\mathrm{Ca}$ from the forest floor to birds and other vertebrates who can have high $\mathrm{Ca}$ requirements. Indeed, the link between acidic deposition and higher trophic level $\mathrm{Ca}$ depletion has been seen for snails and songbirds (Drent and Woldendorp, 1989), and acid deposition in the eastern US is thought to have contributed to declines in the population of wood thrushes (Hylocichla mustelina) (Hames et al., 2002).

Many species of songbirds, even those that eat primarily seeds, change their Ca intake depending on the season (Dhondt and Hochachka, 2001) and eat food sources with high levels of Ca, like snails, during egg laying (Ankney and Scott, 1980), sometimes significantly changing their behavior to seek Ca-rich sources of food (Graveland and Berends, 1997). This increase in bird Ca demand is related to the Ca requirements of eggshell formation combined with the fact that birds cannot store heavy Ca reserves. The net result is that, without additional dietary Ca during egg laying, eggs do not develop properly (Graveland, 1996; Graveland and van Gijzen, 1994). While most studies linking bird declines to acidic deposition through $\mathrm{Ca}$ depletion have focused on snails, Bures and Weidinger (2003) found that some birds, including flycatchers (Ficedula albicollis and Ficedula hypoleuca), need woodlice and millipedes as a source of $\mathrm{Ca}$ in addition to snails.

The Fernow Experimental Forest Long Term Soil Productivity (LTSP) study near Parsons, WV provides a unique opportunity to determine how experimental $\mathrm{N}$ and $\mathrm{S}$ additions have affected a young aggrading temperate deciduous forest, including effects on the populations of a Ca-rich species of millipede - Pseudopolydesmus serratus. This species of millipede is found throughout the experimental site and previous research in 
the Fernow LTSP plots (Fowler et al., unpublished) has found that, after 10-12 years of growth with continual $\mathrm{N}$ and $\mathrm{S}$ addition, soil and foliage showed signs of soil acidification and $\mathrm{Ca}$ and $\mathrm{Mg}$ depletion, despite a lack of negative effects being seen on overall tree growth or litter inputs (Fig 4.1). The soil and foliar Ca levels in experimentally acidified plots also appeared to respond to positively to Ca addition (Fig. 4.1).

Millipedes are saprophagous macroarthropods that process forest leaf litter (David and Handa, 2010) and may be an important source of nutrition for some bird species (Bures and Weidinger, 2003). Millipedes are known to contain high concentrations of Ca relative to most other soil and litter invertebrates except snails (Gist and Crossley, 1975;

Graveland and van Gijzen, 1994; Reichle et al., 1969). The high concentrations of Ca in millipedes strengthens their exoskeleton (Borrell, 2004), and can reflect environmental Ca concentrations (Nakamura and Taira, 2005; Nakamura et al., 2005). There is also evidence that variability in available Ca can alter millipede populations. Kalisz and Powell (2003) found that both snail and millipede numbers were associated with soil Ca variations due to distance from a limestone road, and the diet of millipedes can affect their level of reproduction (David and Celerier, 1997). Thus, changes in the nutrient levels of the food source of millipedes (forest floor litter) due to acidic deposition could lead to population level effects on millipedes. However, I am not aware of any studies linking $\mathrm{Ca}$ depletion due to acidic deposition to millipede abundance and $\mathrm{Ca}$ concentrations. 
Thus, this study used the Fernow LTSP treatment plots to assess the impact of long-term acidic deposition on population size of $P$. serratus millipedes. I hypothesized that the long-term additions of ammonium sulfate would lead to a smaller millipede population in plots receiving elevated inputs. I also hypothesized that limestone additions would mitigate these negative effects because previous work at this site has shown that it can ameliorate reductions in soil and foliar Ca levels caused by long-term additions of ammonium sulfate.

\subsection{Methods.}

This study was conducted in the Fernow Experimental Forest Long Term Soil

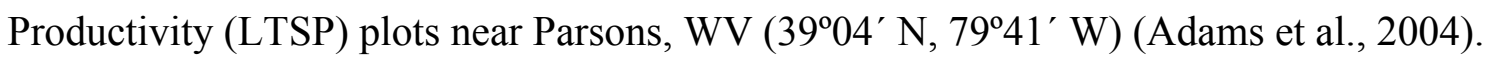
The location of the Fernow LTSP experiment has a SE aspect, and slopes between 15 and 31\%. It is situated in the Allegheny Mountain subsection of the Appalachian Physiographic Province and has an elevation range of $798-847 \mathrm{~m}$. Prior to the initiation of the experiment in 1996, the most recent logging activity occurred in $\sim 1910$, and most trees were $\sim 85$ years old. The forest community before the experiment started was classified as a central Appalachian mixed hardwood forest.

The Fernow LTSP experiment is a randomized block design containing four blocks, each with four plots that receive different treatments (Fig. 4.2). Each treatment plot is 0.4 ha in size (60.9 $\mathrm{m}$ on a side) and includes a 7.6-m wide buffer strip in which no samples 
were collected. The area available for sampling in each plot is 0.2 ha in area (Adams et al., 2004).

The four treatments in the Fernow LTSP study are: (1) reference plots (UNCUT) that were last harvested around 1910, and that received no experimental manipulation as part of the Fernow LTSP study; (2) cut plots (WT) that were subjected to a whole-tree harvest in 1996 in which all aboveground biomass was removed; (3) cut and fertilized plots (WT+NS) that were whole-tree harvested in 1996 and since that time have received annual applications of $35 \mathrm{~kg} \mathrm{~N} / \mathrm{ha}$ as ammonium sulfate to enhance $\mathrm{N}$ and $\mathrm{S}$ inputs and accelerate soil acidification; and (4) cut, fertilized, and limed plots (WT+NS+LIME) that were treated in the same way as the WT+NS plots and that have also received dolomitic lime at an annual rate of $22.5 \mathrm{~kg} \mathrm{Ca} / \mathrm{ha}$ and $11.6 \mathrm{~kg} \mathrm{Mg} / \mathrm{ha}$ since the initiation of the study. The treatments were divided into three applications in March, July, and November (Adams et al., 2004).

In this study, I only examined the harvested plots (WT, WT+NS, and WT+NS+LIME) because I was concerned specifically with the effects of acidic deposition on $P$. serratus millipedes in young, regenerating forest stands. All of these treatment plots underwent a whole tree harvest in 1996 (which was the second major logging event for the forest) and were then allowed to regenerate naturally other than their assigned experimental treatments. Soils are classified as loamy-skeletal, mixed active, mesic typic Dystrudepts and the parent materials are sandstone colluvium, sandstone residuum, and weathered shale (Adams et al., 2004). 
I assessed the effect of these treatments on $P$. serratus populations by sampling the populations with millipede traps. Since millipedes congregate in dark, moist habitats, I constructed millipede traps from $15 \times 15 \mathrm{~cm}$ pieces of plain, corrugated cardboard that were fixed to the ground with landscape fabric pins driven through a slit in their center. Millipede traps were placed at 12 random locations per plot and moistened with water. The next day traps were checked and all P. serratus millipedes present were collected. Traps were returned to the ground and left in place until a rain, after which all $P$. serratus millipedes were again collected. The entire trapping cycle was then repeated with new pieces of cardboard at 12 other random locations per plot. Thus, there were a total of 4 different collection efforts per plot made in June and July, 2009.

All millipedes collected were counted and pooled together for each plot. To more accurately assess their tissue Ca concentrations, I purged the content of their digestive systems by feeding with lettuce for 48 hours. They were then killed with liquid nitrogen and dried for 48 hours at $65 \mathrm{C}$. The dried millipedes were then weighed individually and pooled samples were analyzed for their Ca content on a plot basis. In order to determine Ca content, the millipedes were ground to a homogenous powder in a mortar and pestle and replicate samples were digested using nitric acid and hydrogen peroxide at $125^{\circ} \mathrm{C}$ using a Westco Scientific Instruments AD-4020 block digester according to the method of Jones and Case (1990). Analysis of millipede digests for Ca was done by atomic absorption flame spectroscopy on a Varian Spectra AA 220 FS Atomic Absorption Spectrometer (Varian, 1989). 
I used analysis of variance (ANOVA) to determine if the treatments (ammonium sulfate additions with or without lime) altered the number captured or Ca content of $P$. serratus millipedes. For each variable measured, I set up a two-way ANOVA with the factors being treatment and block (no treatment*block interaction term was included due to lack of replication at this level). Each plot was considered a replicate and the average value for each variable was used for each plot, thus $n=4$. If significant effects of either factor were found, then post hoc Tukey-Kramer tests were run. Assumptions of ANOVA, including normality of residuals and homogeneity of variances were tested, and any necessary transformations were performed. An alpha level of 0.05 was used throughout to assess statistical significance. All statistical tests were performed using SAS JMP version $10(\mathrm{JMP})$.

\subsection{Results.}

Using all the data I found that after 13 years of continuous treatment in Fernow Experimental Forest LTSP plots, no significant effect of treatment was detected on the number of $P$. serratus millipedes collected $(\mathrm{p}=0.213)$ or on the total mass of millipedes collected ( $p=0.147)$. Additionally, I found that there was no effect of the treatments on the Ca concentration in millipede tissue $(\mathrm{p}=0.718)$ (Fig. 4.3). There was also no significant effect of treatment on the mass of individual millipedes $(p=0.316)$, Ca content

per millipede $(\mathrm{p}=0.229)$, or total millipede Ca harvested per plot $(\mathrm{p}=0.140)$ (Table A.2). 
However, despite these null statistical results, the mean number of millipedes collected and mean mass millipedes collected appeared to be $\sim 45 \%$ lower in plots receiving additions of ammonium sulfate (Fig. 4.3). The inability to statistically detect such a seemingly large difference appeared to result from the high variability within treatments and the large standard errors of these means (Fig. 4.3). When I examined the values for the number of millipedes collected per block in each treatment (Fig. 4.4), it was clear that much of this variability was due to the values for block 4, particularly the WT plot in block 4, which had the lowest number of millipedes collected despite being in the treatment with the highest average number collected. I attempted to find a pattern in other measured variables that could explain the two outliers in block 4, particularly the low value in WT plot in block 4 (plot 15) but I was unable to explain the extreme values in terms of soil $\mathrm{Ca}, \mathrm{Al}$, or $\mathrm{N}$ levels, soil $\mathrm{pH}$, foliar $\mathrm{Ca}, \mathrm{Al}$, or $\mathrm{N}$, litter layer thickness, or litterfall mass (Fowler et al., unpublished). In the absence of a direct explanation for the high variability in block 4, I examined the distribution of the residuals obtained from the statistical model and found that both the WT plot and the WT+NS+LIME plot in block 4 had residuals that fell beyond the $90^{\text {th }}$ percentile or below the $10^{\text {th }}$ percentile of the distribution (Fig. 4.5), a characteristic which qualifies these plots as statistical outliers (Gotelli and Ellison, 2004). If I remove all of block 4 plots from the analysis, the influence of these outliers is suppressed (Fig. 4.5) and I am able to detect highly significant effects of treatment that were previously obscured by variation (Fig. 4.6).

Omitting block 4 from the analyses, I found that the addition of ammonium sulfate (with or without lime additions) reduced both the number of millipedes collected ( $\mathrm{p}=0.011)$, the 
total mass of millipedes collected $(\mathrm{p}=0.010)$, and the total millipede Ca harvested per plot $(p=0.022)$ (Fig. 4.6). However, there were still no detectable treatment effects on the Ca concentration in millipede tissue $(p=0.484)$, mass of individual millipedes $(p=0.244)$, or Ca content per millipede $(\mathrm{p}=0.218)$ (Table A.2).

Regardless of whether outliers (i.e., block 4) were included, there was no significant difference for any of the dependent variables between $\mathrm{WT}+\mathrm{NS}$ plots and $\mathrm{WT}+\mathrm{NS}+\mathrm{LIME}$ plots (Table A.2, Fig. 4.3, Fig. 4.6). I also did not detect block effects for any of the dependent variables measured. There were no significant deviations from normality in the distributions of the residuals of any statistical model, so no transformations were needed.

Removing block 4 from the analysis allowed me to statistically detect the effect that was only apparent in the complete data set. Removing this data did not change the direction of the observed effect and only increased its magnitude from about $45-48 \%$ to about 57 $62 \%$ for reduction in the number of millipedes collected, and from about $41-53 \%$ to $57-$ $60 \%$ for the reduction in the mass of millipedes collected (Fig. 4.3, Fig. 4.6).

\subsection{Discussion.}

My results indicated that experimental additions of ammonium sulfate in an aggrading temperate deciduous forest decreased the number of $P$. serratus millipedes captured by about $50 \%(41-62 \%)$, and that the addition of dolomitic lime did not restore their 
numbers. While my method was not suitable for the estimation of actual size of millipede populations, it should provide a reasonable proxy for relative population size. Therefore, it appeared that acidic deposition has the potential to reduce millipede populations in temperate deciduous forests, along with the total pool of millipede Ca that is available to organisms that utilize millipedes as a food and/or Ca source. Surprisingly, however, I also found that adding lime to acidified forests did not mitigate the negative effects of the acidic deposition on millipede populations. And thus, contrary to my expectation, the effects of ammonium sulfate additions were not attributable to changes in the soil and litter that could be mitigated by the addition of lime - changes such as reduced $\mathrm{Ca}$ levels in the soil and in leaf litter.

I also observed that the millipede Ca content per millipede was unchanged by acidification or lime addition. This observation provided further support for the idea that something other than soil or leaf litter Ca levels were driving the differences in millipede captures because the tissue Ca concentration in millipedes has been found to fluctuate in tandem with environmental Ca levels (Nakamura and Taira, 2005), and, in this study, treatments with lower numbers of millipedes did not have lower Ca levels in the millipede tissues.

From previous work, the soil and litter Ca levels in the Fernow LTSP plots were shown to respond negatively to the addition of ammonium sulfate but responded positively to concurrent limestone addition (Fowler et al., unpublished) (Fig. 4.1). Since there was no corresponding positive effect of limestone addition on the $P$. serratus millipedes in this 
study, it appears that the negative effect of ammonium sulfate addition on the millipedes was due to some factor other than Ca depletion. Among possible explanations are variations in litter and soil $\mathrm{N}$ levels, changes in the amount of cover in which millipedes can hide from predators, changes in plant species composition, and/or changes in other aspects of litter quality that might diminish millipede populations (e.g., an enhanced production by plants of defensive compounds).

Previous work in the LTSP plots was either unable to detect differences in these chemical and physical features, or found a pattern of treatments effects there were not consistent with observed differences in millipede numbers. Although foliar $\mathrm{N}$ was higher in plots receiving ammonium sulfate, the likely effects of this on millipedes, if any, would be to increase their populations since plant $\mathrm{N}$ is an important nutrient to invertebrates. Adding ammonium sulfate also caused an increase in the thickness of the litter layer on the forest floor, but this also should have increased rather than decreased millipede populations because in would result in increased habitat and food source, and greater protection. Since the composition of trees in these young forest stands was strongly dominated by a single species ( $P$. pensylvanica) it is also unlikely that any differences in the composition of tree species could account for the observed decreases in millipede numbers. However, one mechanism that could have reduced millipede numbers in response to increased $\mathrm{N}$ inputs that is independent of acidification and $\mathrm{Ca}$ depeletion would be an increase in $\mathrm{N}$ based defensive compounds in foliage. This hypothesis was supported by the fact that the dominant tree species in the LTSP plots (P. pensylvanica) is known to contain Nbased cyanogenic glycosides as anti-herbivory compounds (Kingsbury, 1964). 
Furthermore, it is thought that increases in $\mathrm{N}$ availability can increase the production of these compounds (Kingsbury, 1964).

The reduction in number of millipedes captured combined with no effect on individual millipede Ca content meant that the total amount of millipede calcium harvested per plot was lower in the plots receiving ammonium sulfate additions, even in plots receiving additions of dolomitic limestone. Thus, despite the observation that reduced soil and plant $\mathrm{Ca}$ levels did not appear to affect millipede populations, reductions in millipede populations did reduce the pool of $\mathrm{Ca}$ found in millipede biomass, and may negatively affect any animals relying on millipedes as a food source or as a critical source of dietary Ca.

Millipedes, along with snails and woodlice, are among the few soil invertebrates that contain appreciable amounts of Ca (Gist and Crossley, 1975; Graveland and van Gijzen, 1994; Reichle et al., 1969). Ca deficiencies during reproduction have been found to cause problems in birds. Ca depletion due to acidic deposition has been linked to declines in bird populations in Europe on great tits (Parus major) (Graveland et al., 1994; Hotopp, 2002) and in the US on wood thrushes (Hylocichla mustelina) (Hames et al., 2002). It has also been found that feeding birds Ca-containing food will improve their breeding success (Bures and Weidinger, 2001; Graveland and Drent, 1997). In addition to the direct impacts of $\mathrm{Ca}$ depletion on bird breeding success, both inter- and intraspecies relationships may be affected. The effect of Ca depletion on birds varies depending on species (Pabian and Britingham, 2012; Schlender et al., 2007) and Ca 
depletion has been found to affect territory size in both ovenbirds (Seiurus aurocapilla) (Pabian and Brittingham, 2011) and Louisiana waterthrushes (Seiurus motacilla) (Mulvihill et al., 2008)

Most studies linking bird declines to acidic deposition through Ca depletion have focused on snails. However, Bures and Weidinger (2003) found that some birds, including flycatchers (Ficedula albicollis and Ficedula hypoleuca) need woodlice and millipedes as a source of $\mathrm{Ca}$ in addition to snails, and that up to 3 times as much of the birds' $\mathrm{Ca}$ comes from woodlice and millipedes as comes from snails.

This study documented a new aspect to the prevailing hypothesis that describes how acidic deposition could affect bird populations. Previously, it was thought that birds were affected by acidic deposition through a direct effect of soil and foliar $\mathrm{Ca}$ depletion on the $\mathrm{Ca}$ content in their food sources. Here, however, is evidence that the transmission of $\mathrm{Ca}$ into higher trophic levels could be diminished by factors other than $\mathrm{Ca}$ depletion, and I suggest that one mechanism may be an enhanced production of N-based defensive compounds in response to elevated $\mathrm{N}$ availability.

Independent of direct effects on higher trophic levels, any reduction in millipede populations also has the potential to alter rates of nutrient cycling. Millipedes are important as processers of litter on the forest floor. Litter studies (McCay et al., 2013), millipede feeding studies (Carcamo et al., 2000), and microcosm studies (Bonkowski et al., 1998) have all concluded that millipedes can be important litter processors in the 
forest floor. Millipedes have been found to change both the chemical makeup of the litter (Rawlins et al., 2006) and the type and number of bacteria that are on the litter (Maraun and Scheu, 1996) while the litter is transformed from raw litter to fecal pellet. Additionally, dense millipede populations can serve as a sizeable Ca reservoir (Shaw, 1968). Thus, reductions in millipede populations could lead to changes in the rate of litter decay, rates of nutrient cycling, and shifts in the Ca storage pools of temperate deciduous forests.

In conclusion, I found that $P$. serratus millipedes, leaf litter processing invertebrates that contain high levels of $\mathrm{Ca}$, were negatively affected by simulated acidic deposition in temperate deciduous forests. This negative effect, however, may be linked to the elevated $\mathrm{N}$ inputs rather than lower levels of available $\mathrm{Ca}$. If this result were widespread, it could influence the supply of $\mathrm{Ca}$ to other organisms that rely on millipedes as a significant component of their diet. However, the extent of this effect may be confined to forests with an abundance of species that are capable of producing N-based defensive compounds, such as mature forests with a significant number of black cherry and, as in this case, young forests dominated by pin cherry. 


\subsection{Tables and Figures.}

Figure 4.1. Mean values for soil and foliar Ca levels for the Fernow Experimental Forest LTSP plots after 10 (resin and foliar) and 12 years (extractable) of treatment (Fowler et al., unpublished). Error bars represent one standard error above and below the mean. Values separated by different capital letters are significantly different at $\mathrm{p}<0.05$, and those separated by lowercase letters show a trend towards differences at $\mathrm{p}<0.1$ in post hoc analyses. (LITU $=$ Liriodendron tulipifera, $\mathrm{PRPE}=$ Prunus pensylvanica, $\mathrm{VIRO}=$ Viola rotundifolia)

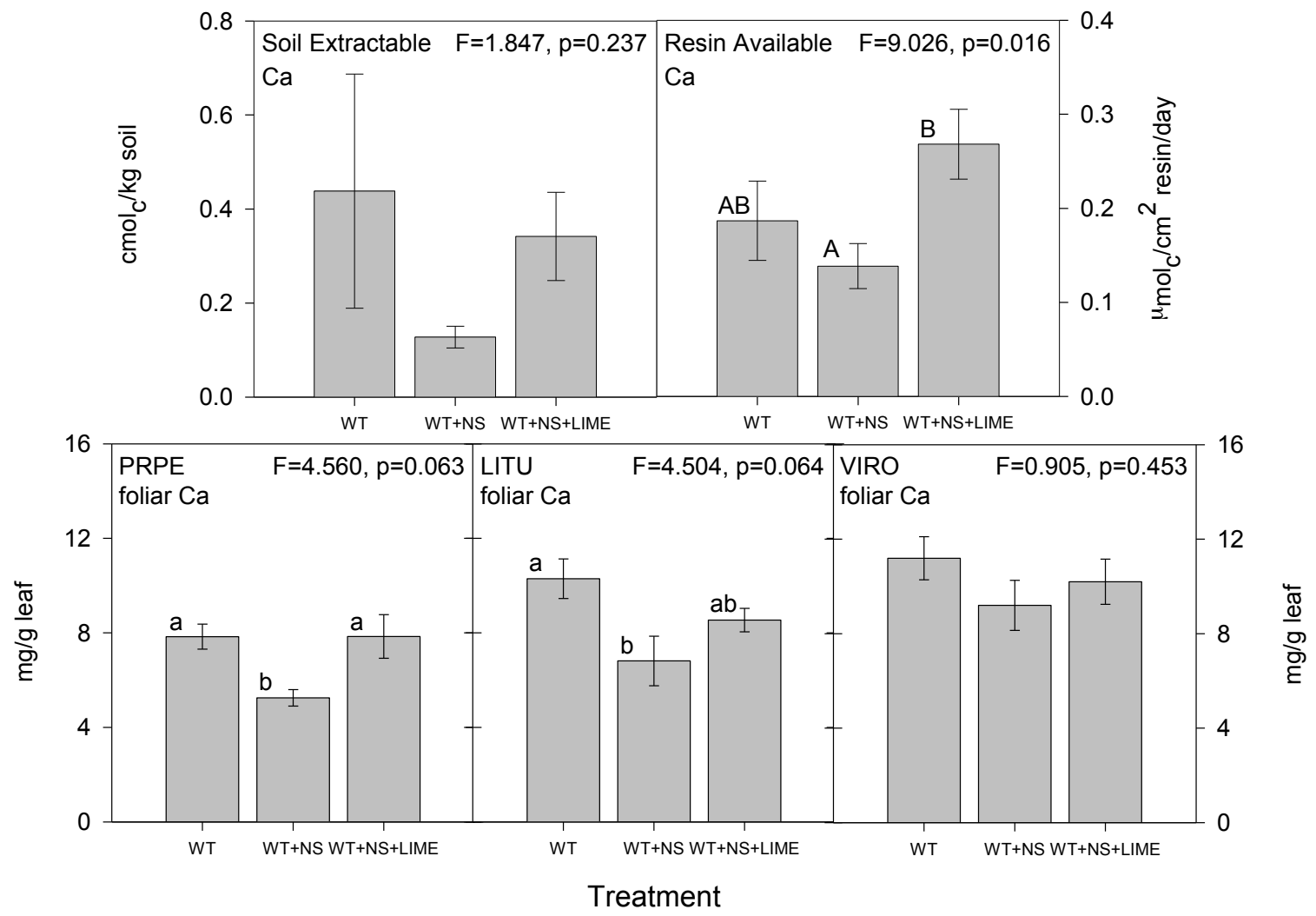


Figure 4.2. The Fernow Experimental Forest Long Term Soil Productivity (LTSP) plots showing blocking and treatment distribution (Adams et al., 2004).

\begin{tabular}{|c|c|c|c|c|}
\hline \multicolumn{4}{|c|}{ Top of slope } & \multirow[b]{2}{*}{ Block 1} \\
\hline $\begin{array}{c}\text { Plot } 4 \\
\text { UNCUT }\end{array}$ & $\begin{array}{c}\text { Plot } 3 \\
\text { WT }\end{array}$ & $\begin{array}{c}\text { Plot } 2 \\
\text { WT+NS+ } \\
\text { LIME }\end{array}$ & $\begin{array}{c}\text { Plot } 1 \\
\text { WT+NS }\end{array}$ & \\
\hline $\begin{array}{l}\text { Plot } 5 \\
\text { WT }\end{array}$ & $\begin{array}{c}\text { Plot } 6 \\
\text { WT+NS }\end{array}$ & $\begin{array}{c}\text { Plot } 7 \\
\text { WT+NS+ } \\
\text { LIME }\end{array}$ & $\begin{array}{c}\text { Plot } 8 \\
\text { UNCUT }\end{array}$ & \multirow[t]{3}{*}{ Block 2} \\
\hline $\begin{array}{l}\text { Plot } 12 \\
\text { WT }\end{array}$ & $\begin{array}{l}\text { Plot } 11 \\
\text { UNCUT }\end{array}$ & $\begin{array}{l}\text { Plot } 10 \\
\text { WT+NS }\end{array}$ & $\begin{array}{c}\text { Plot } 9 \\
\text { WT+NS+ } \\
\text { LIME }\end{array}$ & \\
\hline $\begin{array}{l}\text { Plot } 13 \\
\text { WT+NS }\end{array}$ & $\begin{array}{c}\text { Plot } 14 \\
\text { WT+NS+ } \\
\text { LIME }\end{array}$ & $\begin{array}{l}\text { Plot } 15 \\
\text { WT }\end{array}$ & $\begin{array}{l}\text { Plot } 16 \\
\text { UNCUT }\end{array}$ & \\
\hline \multicolumn{4}{|c|}{ Bottom of slope } & \\
\hline
\end{tabular}


Figure 4.3. Mean number and mass of millipedes collected after 13 years of treatment in the Fernow Experimental Forest Long Term Soil Productivity (LTSP) plots. Error bars represent one standard error above and below the mean.

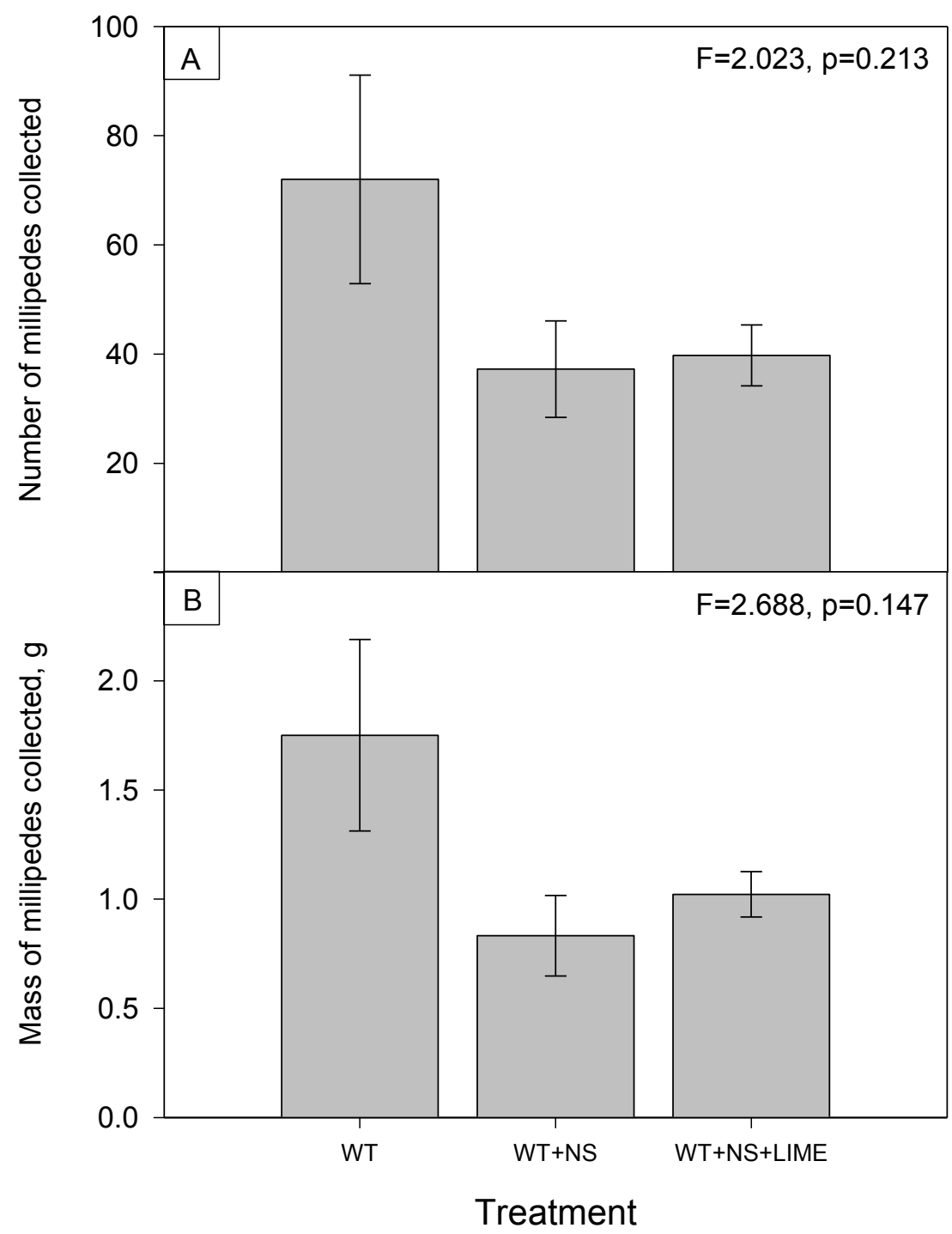


Figure 4.4. Number of millipedes collected after 13 years of treatment in the Fernow Experimental Forest Long Term Soil Productivity (LTSP) plots shown by block and treatment to illustrate the source of the variation evident in Fig. 4.

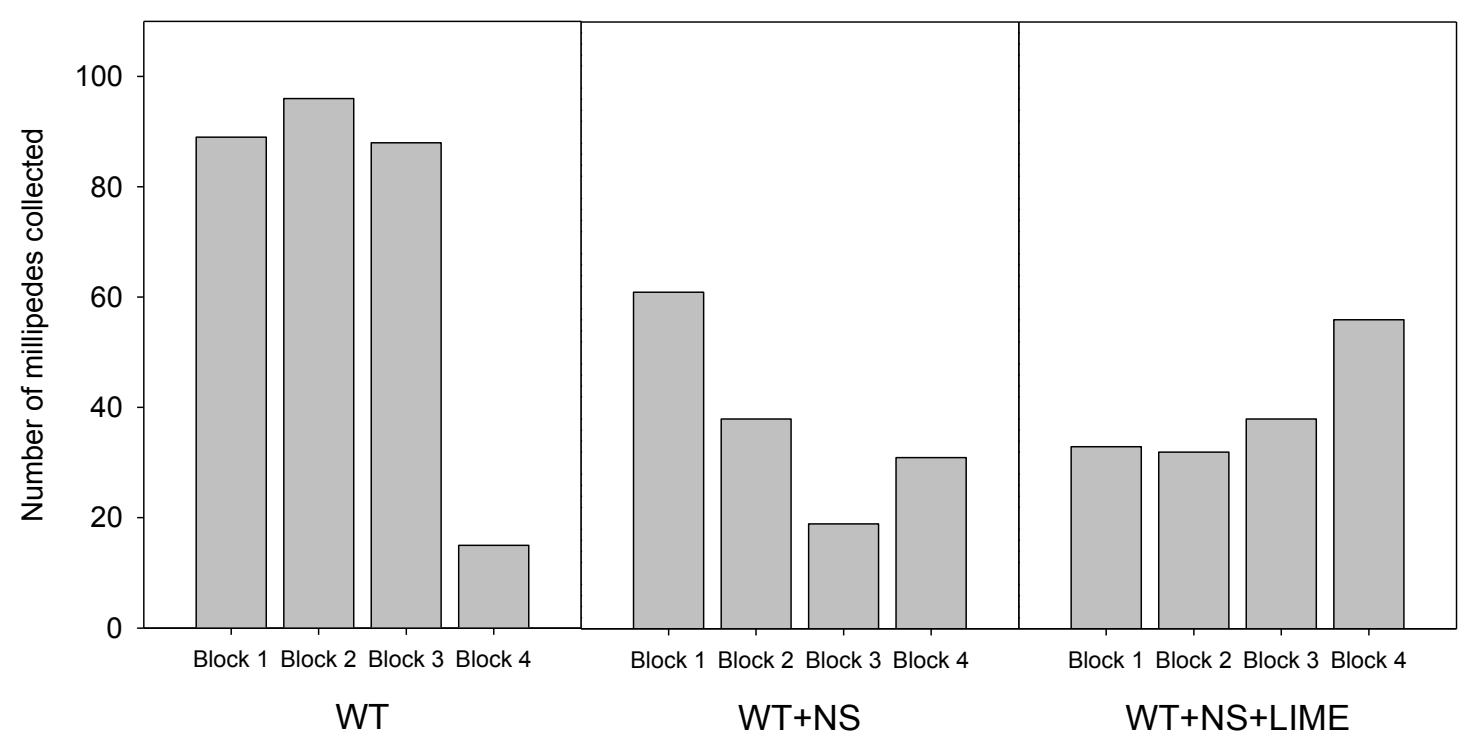


Figure 4.5. Box plot for the residuals of the two-way ANOVA model for number of millipedes collected including and excluding block 4 . The line in the middle of each box represents the median of the residuals, the edges of the box are the $25^{\text {th }}$ and $75^{\text {th }}$ percentiles, and the whiskers are the $10^{\text {th }}$ and $90^{\text {th }}$ percentiles, outliers are shown as points beyond $90^{\text {th }}$ or $10^{\text {th }}$ percentiles. The two outliers evident when block 4 is included correspond to the low value for WT block 4 (plot 15) and the high value for WT+NS+LIME block 4 (plot 14) that can be seen in Fig. 5.

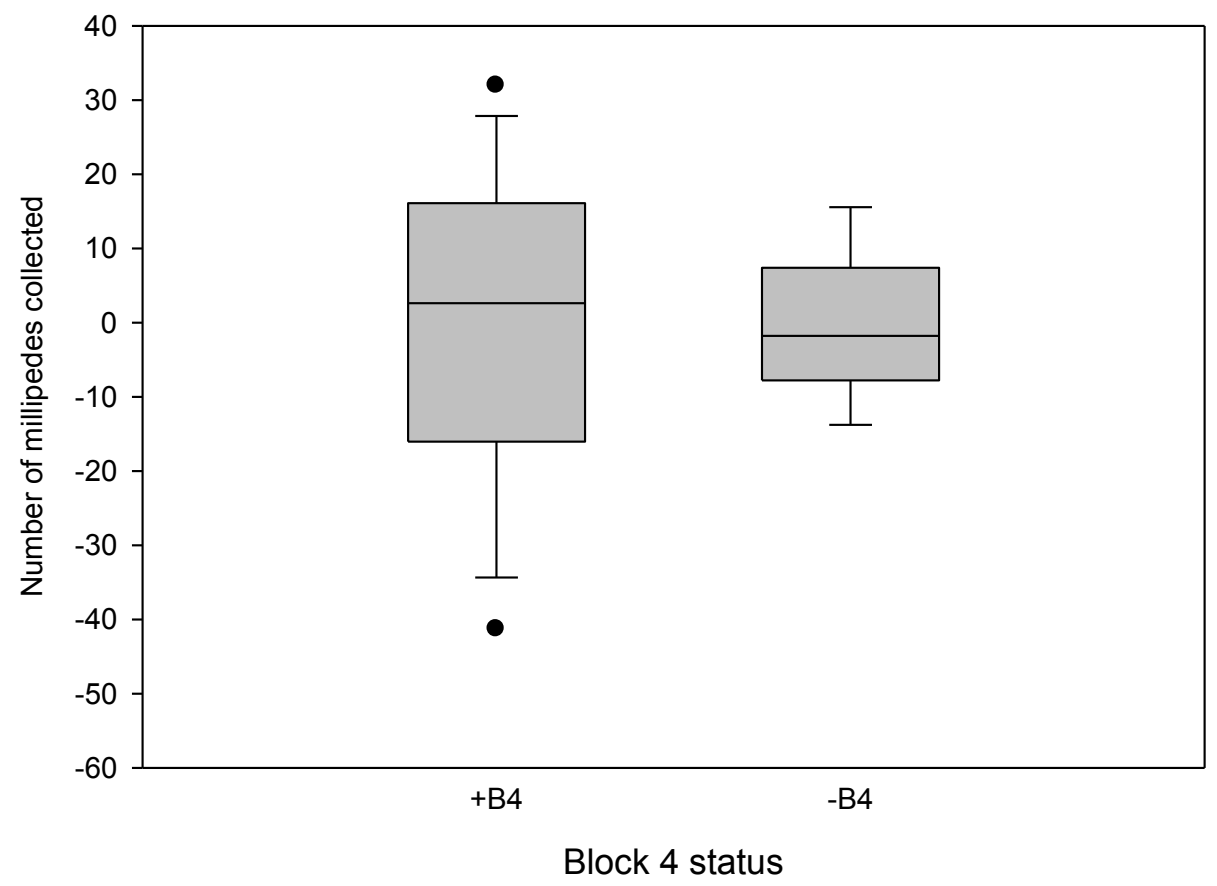


Figure 4.6. Mean number and mass of millipedes collected after 13 years of treatment in the Fernow Experimental Forest Long Term Soil Productivity (LTSP) plots, excluding block 4. Error bars represent one standard error above and below the mean. Bars separated by different letters are significantly different at $\mathrm{p}<0.05$ in post hoc analysis.

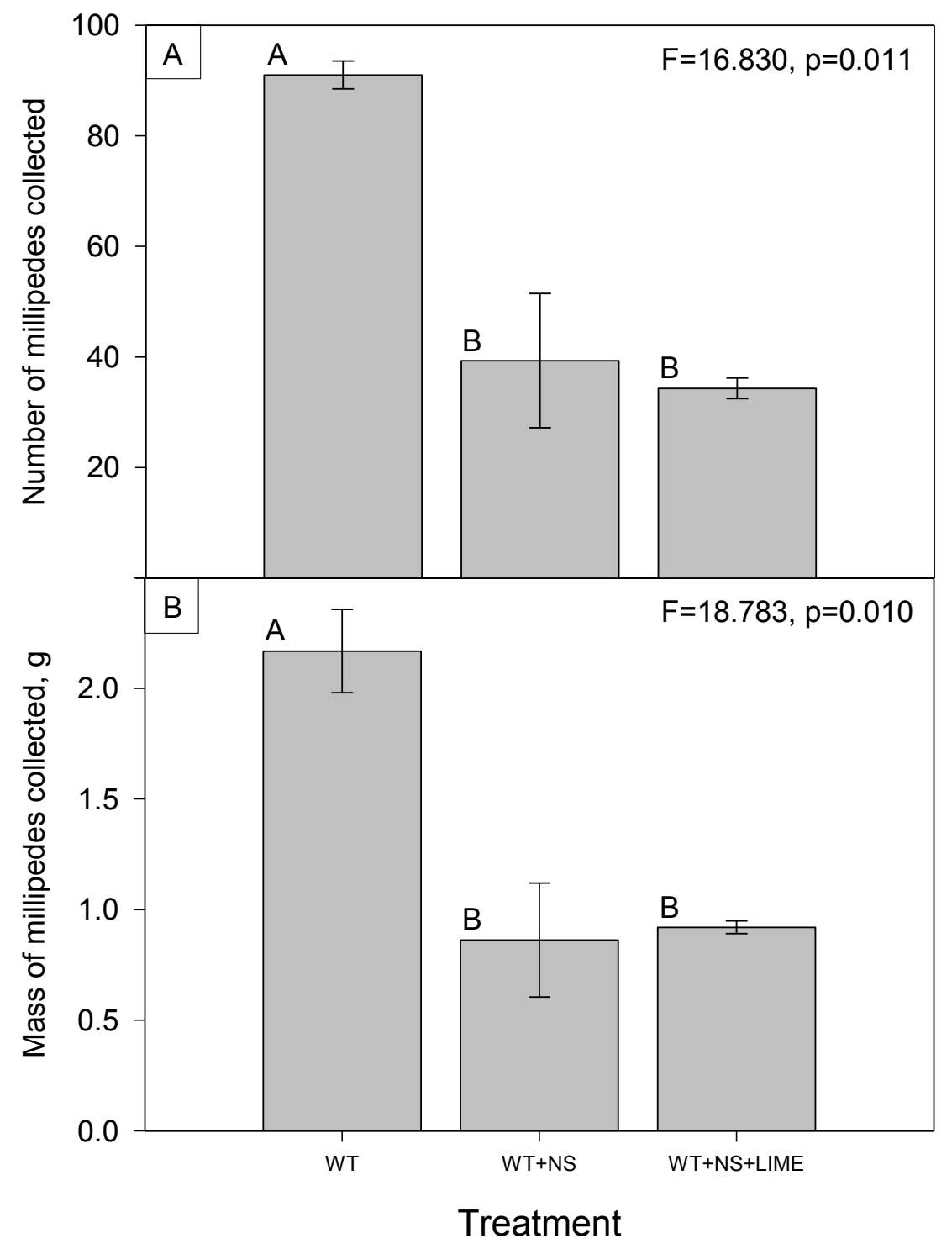




\subsection{Literature Cited.}

Aber, J. D., W. McDowell, K. Nadelhoffer, A. Magill, G. Berntson, M. Kamakea, S. McNulty, W. Currie, L. Rustad, and I. Fernandez. 1998. Nitrogen saturation in temperate forest ecosystems. BioScience 48: 921-934.

Adams, M. B., J. Burger, L. Zelazny, and J. Baumgras. 2004. Description of the Fork Mountain long-term soil productivity study: site characterization. USDA Forest Service, Newtown Square, PA.

Adams, M. B., T. R. Angradi, and J. N. Kochenderfer. 1997. Stream water and soil solution responses to 5 years of nitrogen and sulfur additions at the Fernow Experimental Forest, West Virginia. Forest Ecology and Management 95: 79-91.

Ankney, C. D. and D. M. Scott. 1980. Changes in nutrient reserves and diet of breeding brown-headed cowbirds. The Auk 97: 684-696.

Bailey, S. W., S. B. Horsley, and R. P. Long. 2005. Thirty years of change in forest soils of the Allegheny Plateau, Pennsylvania. Soil Society of America Journal 69: 681-690.

Baumgardner, R. E., T. F. Lavery, C. M. Rogers, and S. S. Isil. 2002. Estimates of the atmospheric deposition of sulfur and nitrogen species: Clean air status and trends network, 1990-2000. Environmental Science and Technology 36: 2614-2629.

Bedison, J. E. and A. H. Johnson. 2010. Seventy-four years of calcium loss from forest soils of the Adirondack Mountains, New York. Soil Society of America Journal 74: $2187-2195$.

Bonkowski, M., S. Scheu, and M. Schaefer. 1998. Interactions of earthworms (Octolasion lacteum), millipedes (Glomeris marginata) and plants (Hordelymus eruopaeus) in a beechwood on a basalt hill: implications for litter decomposition and soil formation. Applied Soil Ecology 9: 161-166.

Borrell, B. 2004. Mechanical properties of calcified exoskeleton from the neotropical millipede, Nyssodesmus python. Journal of Insect Physiology 50: 1121-1126.

Bures, S. and K. Weidinger. 2001. Do pipits use experimentally supplemented rich sources of calcium more often in an acidified area? Journal of Avian Biology 32: 194-198.

Bures, S. and K. Weidinger. 2003. Sources and timing of calcium intake during reproduction in flycatchers. Oecologia 137: 634-641. 
Carcamo, H. A., T. A. Abe, C. E. Prescott, F. B. Holl, and C. P. Chanway. 2000. Influence of millipedes on litter decomposition, $\mathrm{N}$ mineralization, and microbial communities in a coastal forest in British Colombia, Canada. Canadian Journal of Forest Research 30: 817-826.

Chen, L. and C. T. Driscoll. 2004. Modeling the response of soil and surface waters in the Adirondack and Catskill regions of New York to changes in atmospheric deposition and historical land disturbance. Atmospheric Environment 38: 40994109.

David, J. F. and M. L. Celerier. 1997. Effects of yeast on the growth and reproduction of the saprophagous millipede Polydesmus angustus (Diplopoda Polydesmidae). Biol Fertil Soils 24: 66-69.

David, J. F. and I. T. Handa. 2010. The ecology of saprophagous macroarthropods (millipedes, woodlice) in the context of global change. Biological Reviews 85: 881-895.

Dentener, F., D. Stevenson, K. Ellingsen, T. Van Noije, M. Schultz, M. Amann, C. Atherton, N. Bell, D. Bergmann, I. Bey, L. Bouwman, T. Buler, J. Cofala, B. Collins, J. Drevet, R. Doherty, B. Eickhout, H. Eskes, A. Fiore, M Gauss, D. Hauglustaine, L. Horowitz, I S. A. Isaksen, B. Josse, M. Lawrence, M. Krol, J. F. Lamarque, V. Montanaro, J. F. Muller, V. H. Peuch, G. Pitari, J. Pyle, S. Rast, J. Rodriguez, M. Sanderson, N. H. Savage, D. Shindell, S. Strahan, S. Szopa, K. Sudo, R. Van Dingenen, O. Wild, and G. Zeng. 2006. The global atmospheric environment for the next generation. Environmental Science and Technology 40: 3586-3594.

Dhondt, A. A. and W. M. Hochachka. 2001. Variations in calcium use by birds during the breeding season. The Condor 103: 592-598.

Drent, P. J. and J. W. Woldendorp. 1989. Acid rain and eggshells. Nature 339: 431.

Driscoll, C. T., G. B. Lawrence, A. J. Bulger, T. J. Butler, C. S. Cronan, C. Eagar, K. F. Lambert, G. E. Likens, J. L. Stoddard, and K. C. Weathers. 2001. Acidic deposition in the Northeastern United States: Sources and inputs, ecosystem effects, and management strategies. BioScience 51: 180-198.

Elvir, J. A., G. B. Wiersma, M. E. Day, M. S. Greenwood, and I. J. Fernandez. 2006. Effects of enhanced nitrogen deposition on foliar chemistry and physiological processes of forest trees at the Bear Brook Watershed in Maine. Forest Ecology and Management 221: 207-214.

Farr, C., J. Skousen, P. Edwards, S. Connolly, and J. Sencindiver. 2009. Acid soil indicators in forest soils of the Cherry River Watershed, West Virginia. Environmental Monitoring and assessment 158: 343-353. 
Fernandez, I. J., L. E. Rustad, S. A. Norton, J. S. Kahl, and B. J. Cosby. 2003. Experimental acidification causes soil base-cation depletion at the Bear Book Watershed in Maine. Soil Society of America Journal 67: 1909-1919.

Fernandez, I. J., M. B. Adams, M. D. SanClements, and S. A. Norton. 2010. Comparing decadal responses of whole-watershed manipulations at the Bear Brook and Fernow experiments. Environmental Monitoring and Assessment.

Galloway, J. N., F. J. Dentener, D. G. Capone, E. W. Boyer, R. W Howarth, S. P. Seitzinger, G. P. Asner, C. C. Cleveland, P. A. Green, E. A. Holland, D. M. Karl, A. F. Michaels, J. H. Porter, A. R. Townsend, and C. J. Vorosmarty. 2004. Nitrogen cycles: past, present, and future. Biogeochemistry 70: 153-226.

Gbondo-Tugbawa, S. S. and C. T. Driscoll. 2003. Factors controlling long-term changes in soil pools of exchangeable basic cations and stream acid neutralizing capacity in a northern hardwood forest ecosystem. Biogeochemistry 63: 161-185.

Gist, C. S. and D. A. Crossley, Jr. 1975. The litter arthropod community in a Southern Appalachian hardwood forest: Numbers, biomass and mineral element content. American Midland Naturalist 93: 107-122.

Graveland, J. and A. Berends. 1997. Timing of the calcium intake and effect of calcium deficiency on behaviour and egg laying in captive great tits, Parus major. Physiological Zoology 70: 74-84.

Graveland, J. and R. H. Drent. 1997. Calcium availability limits breeding success of passerines on poor soils. Journal of Animal Ecology 66: 279-288.

Graveland, J. and R. van der Wal. 1996. Decline in snail abundance due to soil acidification causes eggshell defects in forest passerines. Oecologia 105: 351360 .

Graveland, J., R. van der Wal, J. H. van Balen, and A. J. van Noordwijk. 1994. Poor reproduction in forest passerines from decline of snail abundance on acidified soils. Nature 368: 1994.

Graveland, J. and T. van Gijzen. 1994. Arthropods and seeds are not sufficient as calcium sources for shell formation and skeletal growth in passerines. Ardea 82: 299-314.

Graveland, J. 1996. Avian eggshell formation in calcium-rich and calcium-poor habitats: importance of snail shells and anthropogenic calcium sources. Canadian Journal of Zoology 74: 1035-1044. 
Hames, R. S., K. V. Rosenberg, J. D. Lowe, S. E. Barker, and A. A. Dhondt. 2002. Adverse effects of acid rain on the distribution of the wood thrush Hylocichla mustelina in North America. Proceedings of the National Academy of Sciences of the United States of America 99: 11235-11240.

Hogberg, P., H. Fan, M. Quist, D. Binkley, and C. O. Tamm. 2006. Tree growth and soil acidification in response of 30 years of experimental nitrogen loading on boreal forest. Global Change Biology 12: 489-499.

Hotopp, K. P. 2002. Land snails and soil calcium in central Appalachian mountain forest. Southeastern Naturalist 1: 27-44.

Houle, D., S. Tremblay, and R. Ouimet. 2007. Foliar and wood chemistry of sugar maple along a gradient of soil acidity and stand health. Plant and Soil 300: 173 183.

Hruska, J., F. Oulehle, P. Samonil, J. Sebesta, K. Tahovska, R. Hleb, J. Houska, and J. Sik1. 2012. Long-term forest soil acidification, nutrient leaching and vegetation development: Linking modeling and surveys of a primeval spruce forest in the Ukrainian Transcarpathian Mts. Ecological modeling 244: 28-37.

JMP, Version 10. SAS Institute Inc., Cary, NC, 1989-2007.

Johannessen, L. E. and T. Solhoy. 2001. Effects of experimentally increased calcium levels in the litter on terrestrial snail populations. Pedobiologia 45: 234-242.

Johnson, A. H., A. Moyer, J. E. Bedison, S. L. Richter, and S. A. Willig. 2008. Seven decades of calcium depletion in organic horizons of Adirondack forest soils. Soil Science Society of America Journal 72: 1824-1830.

Jones, J. B. and V. W. Case. 1990. Sampling, handling, and analyzing plant tissue samples. In: R. I. Westerman (Ed.), Soil testing and plant analysis. Soil Society of America, Madison, WI, p. 389-427.

Kalisz, P. J. and J. E. Powell. 2003. Effect of calcareous road dust on land snails (Gastropoda: Pulmonata) and millipedes (Diplopoda) in acid forest soils of the Daniel Boone National Forest of Kentucky, USA. Forest Ecology and Management 186: 177-183.

Kingsbury, J. M. 1964. Poisonous plants of the United States and Canada. Prentice-Hall Inc., Englewood Cliffs, NJ, USA. 626 p.

Likens, G. E., C. T. Driscoll, and D. C. Busso. 1996. Long-term effects of acid rain: Response and recovery of a forest ecosystem. Science 272: 244-246. 
Lucash, M. S., R. D. Yanai, J. D. Blum, and B. B. Park. 2012. Foliar nutrient concentrations related to soil sources across a range of sites in the Northeastern United States. Soil Science Society of America Journal 76: 674-683.

Maraun, M. and S. Scheu. 1996. Changes in microbial biomass, respiration and nutrient status of beech (Fagus sylvatica) leaf litter processed by millipedes (Glomeris marginata). Oecologia 107: 131-140.

McCay, T. S., C. L. Cardelus, and M. A. Neatrour. 2013. Rate of litter decay and litter macroinvertebrates in limed and unlimed forests of the Adirondack Mountains, USA. Forest Ecology and Management 304: 254-260.

Miller, D. E. and S. A. Watmough. 2009. Soil acidification and foliar nutrient status of Ontario's deciduous forest in 1986 and 2005. Environmental Pollution 157: 664672.

Mulvihil, R. S., F. L. Newell, and S. C. Latta. 2008. Effects of acidification on the breeding ecology of a stream-dependent songbird, the Louisiana waterthrush (Seiurus motacilla). Freshwater Biology 53: 2158-2169.

Nakamura, K. and J. Taira. 2005. Distribution of elements in the millipede, Oxidus gracilis C. L. Koch (Polydesmida: Paradoxosomatidae) and the relation to environmental habitats. BioMetals 18: 651-658.

Nakamura, K., J. Taira, and Y. Higa. 2005. Internal elements of the millipede, Chamberlinius hualienensis Wang (Polydesmida: Paradoxosomatidae). Applied Entomological Zoology 40: 283-288.

Pabian, S. E. and M. C. Brittingham. 2011. Soil calcium availability limits forest songbird productivity and density. The Auk 128: 441-447.

Pabian, S. E. and M. C. Brittingham. 2012. Soil calcium and forest birds: Indirect links between nutrient availability and community composition. Ecosystems 15: 748760 .

Rawlins, A. J., I. D. Bull, N. Poirier, P. Ineson, and R. P. Evershed. 2006. The biochemical transformation of oak (Quercus robur) leaf litter consumed by the pill millipede (Glomeris marginata). Soil Biology and Biochemistry 38: 1063 1076.

Reichle, D. E., M. H. Shanks, and D. A. Crossley. 1969. Calcium, potassium, and sodium content of forest floor arthropods. Annals of the Entomological Society of America 62: 57-62. 
Schaberg, P. G., D. H. DeHayes, and G. J. Hawley. 2001. Anthropogenic calcium depletion: a unique threat to forest ecosystem health? Ecosystem Health 7: 214228.

Schlender, M., A. Skibbe, J. Kappes, and W. Topp. 2007. Complex responses of songbirds to soil acidification of managed beech forests in Central Europe. Ecosystems 10: 579-587.

Shaw, G. G. 1968. Population size, ecology and mineral reservoir of the millipede, Narceus annularis (RAF.). Ecology 49: 1163-1166.

Skeldon, M. A., M. A. Vadeboncoeur, S. P. Hamburg, and J. D. Blum. 2007. Terrestrial gastropod responses to an ecosystem level calcium manipulation in a northern hardwood forest. Canadian Journal of Zoology 85: 994-1007.

United States Environmental Protection Agency. 2013. CASTNet 2011 annual report. AMEC Environment and Infrastructure, Inc., Washington, DC.

Varian. 1989. Analytical methods. Varian Australia Pty Ltd. Mulgrave, Victoria, Australia.

Wallace, Z. P., G. M. Lovett, J. E. Hart, and B. Machona. 2007. Effects of nitrogen saturation on tree growth and death in a mixed-oak forest. Forest Ecology and Management 243: 210-218. 
Chapter 5. General conclusions about the effects of accelerated soil acidification on aggrading temperate deciduous forests. 
Using the Fernow Experimental Forest Long Term Soil Productivity (LTSP) plots, I was able to test several hypotheses based on our current understanding of: 1) how nitrogen (N) additions may alter forests in ways that affect their ability to sequester carbon (C); 2) how changes in soil and plant-tissue chemistry might constrain the magnitude and longevity of any $\mathrm{N}$-induced enhancement of $\mathrm{C}$ sequestration; and 3) the response of litterprocessing invertebrates that might have implications for their predators.

With respect to $\mathrm{N}$-induced changes in $\mathrm{C}$ sequestration, I examined: 1) whether $\mathrm{N}$ additions directly increased aboveground growth of regenerating trees but did so in a way that was independent of the indirect effects of acidification (e.g. loss of nutrient cations, lower soil $\mathrm{pH}$, and/or elevated aluminum $\left.\left(\mathrm{Al}^{3+}\right)\right)$; 2) whether $\mathrm{N}$ additions directly (independent of acidification effects) enhanced forest floor and soil C pools, and lowered the fine root $\mathrm{C}$ pool; 3) if $\mathrm{N}$ additions lowered stand density and diversity; and 4) whether tree species were differentially affected by either $\mathrm{N}$ fertilization or soil acidification. I found that 13 years of ammonium sulfate additions to a regenerating deciduous forest stimulated its ability to store $\mathrm{C}$ - even in a region with historically high levels of atmospheric $\mathrm{N}$ deposition. This response was driven primarily by increased $\mathrm{C}$ storage in aboveground biomass $(27 \%)$ and to a lesser extent by increased $\mathrm{C}$ stored in the smaller forest floor pool (35\%). Despite the dominance of pin cherry ( $P$. pensylvanica), the overall response was a complex mixture of species-specific changes in the growth of individuals that may have been tempered by changes in stand density - rather than simply a function of how the dominant species responded. Indirect effects of $\mathrm{N}$ additions that could be mitigated by lime additions were found to significantly increase $\mathrm{C}$ accumulation 
in the forest floor and decrease the number of tree species. Given the differential responses observed for longer-lived tree species versus the positive response for shortlived species, it appears that the long-term effects of $\mathrm{N}$ deposition on $\mathrm{C}$ storage in temperate deciduous forests may be different than the short-term effects and may even be detrimental.

I also examined how changes in soil and plant-tissue chemistry might constrain the magnitude and longevity of any $\mathrm{N}$-induced enhancement of $\mathrm{C}$ sequestration by measuring the nutrient levels in soil and foliar samples from the Fernow LTSP. Using these measurements I attempted to detect symptoms before cumulative growth was negatively impacted and that, if allowed to persist, would have the potential to diminish any initial growth enhancements. I found that after at least 10 years of growth with annual ammonium sulfate additions, soil and foliar chemistry in an aggrading temperate deciduous forest showed signs of the onset of soil acidification and calcium $(\mathrm{Ca})$ and magnesium (Mg) depletion. Additionally, I found that liming might mitigate some of the negative impacts of acidification for experimental or management purposes. Specifically, I found patterns of decreases in soil and foliar $\mathrm{Ca}$ and $\mathrm{Mg}$ levels and increases in soil and foliar Al levels in plots receiving experimental ammonium sulfate additions when compared to plots not receiving these additions or plots receiving both ammonium sulfate and dolomitic limestone. These results were similar to the results found in a nearby watershed acidification experiment, and suggested that the initial increase in tree growth following $\mathrm{N}$ additions could be short-lived without any concurrent mitigation. 
Finally, I used the Fernow LTSP plots to determine if there is potential for the effects of accelerated $\mathrm{N}$ deposition to cascade upward into litter-processing invertebrates and their predators. I hypothesized declines in populations of leaf litter processing Pseudopolydesmus serratus millipedes, which have high levels of $\mathrm{Ca}$ in their exoskeletons I also hypothesized the mitigation of this decline with lime addition. Millipede populations were estimated by "trapping" millipedes and millipede Ca pools were estimated by analyzing captured millipedes for Ca content. I found that the number and mass of $P$. serratus millipedes were reduced by $\sim 50 \%$ after 13 years of simulated acidic deposition in temperate deciduous forests. Surprisingly, however, the negative effect of $\mathrm{N}$ addition on millipede populations was not the result of a depletion of $\mathrm{Ca}$ from the soil and plant tissues, but may instead be related to a $\mathrm{N}$-caused plant response, such as enhanced levels of N-based defensive compounds. Despite decreases in the number of millipedes not being caused by $\mathrm{Ca}$ depletion, the potential still exists to effect predators who depend on this species as an important source of dietary $\mathrm{Ca}$.

The overall message from this research is that elevated $\mathrm{N}$ deposition has the potential, in the short-term at least, to increase growth and $\mathrm{C}$ sequestration of temperate deciduous forests growing on soil derived from base-poor parent material. I found evidence that this growth increase may be short-lived because it involved mainly early successional trees and there is evidence of differential species responses and potentially long-lasting negative changes in soil and foliage stemming from $\mathrm{N}$ saturation that could preclude a reduction in growth. I also showed that there is potential for higher trophic levels to be impacted by chemical changes in soil and foliage induced by $\mathrm{N}$ addition. It also seems 
like there is potential for acidic deposition to change stand development trajectories and forest species composition because I found accelerated self-thinning for the four most important tree species, and species-specific tree responses to $\mathrm{N}$ inputs.

This research is particularly important because disturbance of various types is common in temperate deciduous forests in areas impacted by acidic deposition. Understanding the way these regrowing forests will respond to $\mathrm{N}$ inputs will help us understand how forests interact with the global $\mathrm{C}$ cycle. It is important to monitor the effects of acidic deposition on forest soils and the potential for mitigation because the theoretical impacts of soil acidification, some of which we observed, can be long-lasting in forests growing on soils derived from base-poor parent materials. This research will also provide an important starting point for the extended study of the impact of acidic deposition on tree diversity and species composition in temperate deciduous forests in a changing climate. 
Appendix. Additional tables of data. 
Table A.1. Soil and foliar chemistry data after 10 (foliar and resin available) and 12 (extractable) years of treatment. Values presented are means (standard errors), and all statistics are for treatment effects. Values separated by different capital letters are significantly different at $\mathrm{p}<0.05$, and those separated by different lowercase letters show a trend towards differences at $\mathrm{p}<0.1$ in post hoc analyses. (LITU $=$ Liriodendron tulipifera, $\mathrm{PRPE}=$ Prunus pensylvanica, $\mathrm{VIRO}=$ Viola rotundifolia $)$

\begin{tabular}{|c|c|c|c|c|c|c|}
\hline & & WT & WT+NS & WT+NS+LIME & $\mathrm{F}$ & $p$ \\
\hline & Soil pH (in $0.1 \mathrm{M} \mathrm{CaCl}_{2}$ ) & $4.12(0.064) \mathrm{A}$ & $3.76(0.073) \mathrm{B}$ & $4.01(0.046) \mathrm{A}$ & 10.643 & 0.011 \\
\hline & Soil N, \% & $0.329(0.031)$ & $0.330(0.039)$ & $0.341(0.030)$ & 0.225 & 0.805 \\
\hline \multirow{7}{*}{$\begin{array}{c}\text { Soil } \\
\text { extractable }\end{array}$} & $\mathrm{Ca}, \mathrm{cmol}_{\mathrm{c}} / \mathrm{kg}$ & $0.438(0.249)$ & $0.128(0.023)$ & $0.342(0.094)$ & 1.847 & 0.237 \\
\hline & $\mathrm{Mg}, \mathrm{cmol}_{\mathrm{c}} / \mathrm{kg}$ & $0.104(0.036) A B$ & $0.061(0.006) \mathrm{B}$ & $0.143(0.014) \mathrm{A}$ & 5.736 & 0.041 \\
\hline & $\mathrm{Al}, \mathrm{cmol}_{\mathrm{c}} / \mathrm{kg}$ & $0.106(0.012)$ & $0.154(0.017)$ & $0.113(0.019)$ & 3.102 & 0.119 \\
\hline & $\mathrm{Ca}, \mathrm{kg} / \mathrm{ha}$ top $5 \mathrm{~cm}$ & $30.72(17.47)$ & $8.95(1.62)$ & $23.97(6.58)$ & 1.847 & 0.237 \\
\hline & $\mathrm{Mg}, \mathrm{kg} / \mathrm{ha}$ top $5 \mathrm{~cm}$ & $4.43(1.55) A B$ & $2.58(0.26) \mathrm{B}$ & $6.07(0.62) \mathrm{A}$ & 5.736 & 0.041 \\
\hline & $\mathrm{Al}, \mathrm{kg} / \mathrm{ha}$ top $5 \mathrm{~cm}$ & $3.34(0.38)$ & $4.83(0.52)$ & $3.57(0.58)$ & 3.102 & 0.119 \\
\hline & Molar Ca:Al ratio & $8.03(5.61)$ & $1.27(0.19)$ & $4.86(1.33)$ & 1.241 & 0.354 \\
\hline \multirow{4}{*}{$\begin{array}{c}\text { Soil } \\
\text { resin available }\end{array}$} & $\mathrm{Ca}, \mu \mathrm{mol}_{\mathrm{c}} / \mathrm{cm}^{2}$ resin/day & $0.187(0.042) A B$ & $0.139(0.024) \mathrm{A}$ & $0.268(0.037) \mathrm{B}$ & 9.026 & 0.016 \\
\hline & $\mathrm{Mg}, \mu \mathrm{mol}_{\mathrm{c}} / \mathrm{cm}^{2}$ resin/day & $0.0594(0.0123) \mathrm{A}$ & $0.0436(0.0041) \mathrm{A}$ & $0.1150(0.0129) \mathrm{B}$ & 15.151 & 0.005 \\
\hline & $\mathrm{Al}, \mu \mathrm{mol}_{\mathrm{c}} / \mathrm{cm}^{2}$ resin/day & $0.0266(0.0036) \mathrm{A}$ & $0.0514(0.0076) \mathrm{B}$ & $0.0492(0.0069) A B$ & 6.453 & 0.032 \\
\hline & Molar Ca:Al ratio & $11.79(3.63) \mathrm{a}$ & $4.01(0.26) b$ & $8.38(1.05) a b$ & 3.367 & 0.105 \\
\hline \multirow{5}{*}{ LITU foliar } & $\mathrm{Ca}, \mathrm{mg} / \mathrm{g}$ & $10.29(0.84) a$ & $6.81(1.05) b$ & $8.54(0.50) a b$ & 4.504 & 0.064 \\
\hline & $\mathrm{Mg}, \mathrm{mg} / \mathrm{g}$ & $2.34(0.22) \mathrm{A}$ & $1.82(0.26) \mathrm{A}$ & $3.64(0.29) \mathrm{B}$ & 9.881 & 0.013 \\
\hline & $\mathrm{Al}, \mathrm{mg} / \mathrm{g}$ & $0.347(0.025)$ & $0.347(0.019)$ & $0.303(0.017)$ & 0.546 & 0.606 \\
\hline & $\mathrm{N}, \%$ & $3.37(0.132) a$ & $3.82(0.043) b$ & $3.74(0.162) a b$ & 4.871 & 0.055 \\
\hline & Molar Ca:Al ratio & $20.08(1.65) \mathrm{a}$ & $13.52(2.69) b$ & $19.03(1.14) a b$ & 3.970 & 0.080 \\
\hline \multirow{5}{*}{ PRPE foliar } & $\mathrm{Ca}, \mathrm{mg} / \mathrm{g}$ & $7.84(0.53) a$ & $5.25(0.35) b$ & $7.85(0.92) a$ & 4.560 & 0.063 \\
\hline & $\mathrm{Mg}, \mathrm{mg} / \mathrm{g}$ & $1.79(0.10) \mathrm{A}$ & $1.43(0.15) \mathrm{A}$ & $2.45(0.14) \mathrm{B}$ & 15.649 & 0.004 \\
\hline & $\mathrm{Al}, \mathrm{mg} / \mathrm{g}$ & $0.053(0.0072)$ & $0.058(0.0059)$ & $0.061(0.0086)$ & 0.546 & 0.606 \\
\hline & $\mathrm{N}, \%$ & $2.50(0.097) \mathrm{A}$ & $3.13(0.122) B$ & $3.02(0.072) \mathrm{B}$ & 20.991 & 0.002 \\
\hline & Molar Ca:Al ratio & $101.33(5.62)$ & $63.43(10.14)$ & $92.77(19.40)$ & 2.507 & 0.162 \\
\hline \multirow{5}{*}{ VIRO foliar } & $\mathrm{Ca}, \mathrm{mg} / \mathrm{g}$ & $11.19(0.91)$ & $9.20(1.06)$ & $10.20(0.96)$ & 0.905 & 0.453 \\
\hline & $\mathrm{Mg}, \mathrm{mg} / \mathrm{g}$ & $4.69(0.53) A B$ & $3.80(0.16) \mathrm{A}$ & $6.12(0.23) \mathrm{B}$ & 9.488 & 0.014 \\
\hline & $\mathrm{Al}, \mathrm{mg} / \mathrm{g}$ & $0.28(0.014)$ & $0.36(0.030)$ & $0.33(0.038)$ & 2.416 & 0.170 \\
\hline & $\mathrm{N}, \%$ & $2.17(0.133) \mathrm{A}$ & $2.64(0.187) A B$ & $3.01(0.140) \mathrm{B}$ & 6.860 & 0.028 \\
\hline & Molar Ca:Al ratio & $27.14(2.87)$ & $17.82(3.53)$ & $21.78(3.67)$ & 2.196 & 0.193 \\
\hline
\end{tabular}


Table A.2. Average values for all variables measured after 13 years of treatment in Fernow Experimental Forest LTSP. Values in parentheses are standard errors, and pvalues are for treatment effects. Values are also presented for the same data, excluding block 4 due data due to outliers.

\begin{tabular}{|c|c|c|c|c|c|}
\hline & & \multicolumn{3}{|c|}{ Treatment } & \multirow{2}{*}{$\begin{array}{c}\text { Treatmen } \\
\text { p-value }\end{array}$} \\
\hline & & WT & WT+NS & WT+NS+LIME & \\
\hline \multirow{6}{*}{$\begin{array}{c}\text { With } \\
\text { Block } 4\end{array}$} & Number of millipedes collected & $72(19.1)$ & $37.3(8.8)$ & $39.8(5.6)$ & 0.213 \\
\hline & Mass of millipedes collected, $\mathrm{g}$ & $1.75(0.44)$ & $0.83(0.19)$ & $1.02(0.10)$ & 0.147 \\
\hline & Mass per millipede, mg & $25.29(3.13)$ & $20.11(1.04)$ & $24.27(2.26)$ & 0.316 \\
\hline & Ca conc. (mg Ca/g millipede) & $130.57(2.05)$ & $122.77(5.22)$ & $126.88(10.20)$ & 0.718 \\
\hline & Ca content (mg Ca/millipede) & $3.29(0.37)$ & $2.48(0.20)$ & $3.10(0.45)$ & 0.229 \\
\hline & Total Ca harvested (mg/plot) & $250.96(78.23)$ & $96.46(27.85)$ & $120.49(16.71)$ & 0.140 \\
\hline \multirow{6}{*}{$\begin{array}{l}\text { Without } \\
\text { Block } 4\end{array}$} & Number of millipedes collected & $91(2.5)$ & $39.3(12.1)$ & $34.3(1.9)$ & 0.011 \\
\hline & Mass of millipedes collected, $\mathrm{g}$ & $2.17(0.19)$ & $0.86(0.26)$ & $0.92(0.03)$ & 0.010 \\
\hline & Mass per millipede, $\mathrm{g}$ & $27.07(3.64)$ & $19.51(1.20)$ & $23.76(3.11)$ & 0.244 \\
\hline & Ca conc. (mg Ca/g millipede) & $130.08(2.43)$ & $122.93(6.38)$ & $134.93(7.67)$ & 0.484 \\
\hline & Ca content (mg Ca/millipede) & $3.51(0.37)$ & $2.41(0.23)$ & $3.25(0.52)$ & 0.218 \\
\hline & Total Ca harvested (mg/plot) & $321.45(41.55)$ & $100.90(33.67)$ & $111.20(17.01)$ & 0.022 \\
\hline
\end{tabular}

